Nevada

Environmental

Restoration

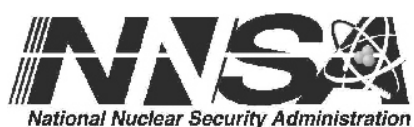

Project

\title{
Closure Report for Corrective Action Unit 574: Neptune Nevada National Security Site, Nevada
}

Controlled Copy No::

Revision: 0

April 2012

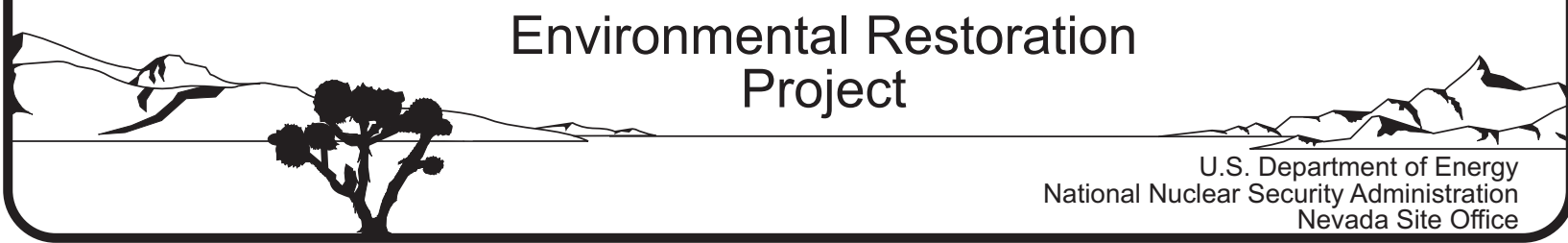




\section{DISCLAIMER}

Reference herein to any specific commercial product, process, or service by trade name, trademark, manufacturer, or otherwise, does not necessarily constitute or imply its endorsement, recommendation, or favoring by the United States Government or any agency thereof.

This report has been reproduced directly from the best available copy.

Available for sale to the public from:

U.S. Department of Commerce

National Technical Information Service

5301 Shawnee Road

Alexandria, VA 22312

Telephone: (800) 553-6847

Fax: (703) 605-6900

E-mail: orders@ntis.gov

Online ordering: http://www.ntis.gov/help/ordermethods.aspx

Available electronically at http://www.osti.gov/bridge.

Available for a processing fee to the U.S. Department of Energy and its contractors, in paper, from:

U.S. Department of Energy

Office of Scientific and Technical Information

P.O. Box 62

Oak Ridge, TN 37831-0062

Telephone: (865) 576-8401

Fax: (865) 576-5728

E-mail: reports@adonis.osti.gov 


\title{
CLOSURE REPORT FOR CORRECTIVE ACTION UNIT 574: NEPTUNE, NEVADA NATIONAL SECURITY SITE, NEVADA
}

\author{
U.S. Department of Energy \\ National Nuclear Security Administration \\ Nevada Site Office \\ Las Vegas, Nevada
}

Controlled Copy No.

Revision: 0

April 2012 
THIS PAGE INTENTIONALLY LEFT BLANK 


\section{CLOSURE REPORT FOR CORRECTIVE ACTION UNIT 574: NEPTUNE, NEVADA NATIONAL SECURITY SITE, NEVADA}

Approved By: /s/: Kevin Cabble

Kevin J. Cabble

Soils Federal Sub-Project Director

Environmental Restoration Project

Approved By: /s/: Robert F. Boehlecke

Robert F. Boehlecke

Federal Project Director

Environmental Restoration Project
Date: $4-25=12$

Date: $4 / 20^{\prime} / 12$ 
THIS PAGE INTENTIONALLY LEFT BLANK 


\section{TABLE OF CONTENTS}

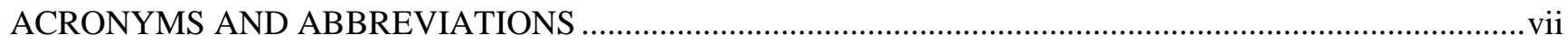

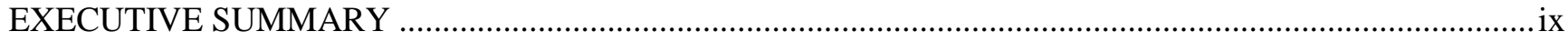

1.0 INTRODUCTION

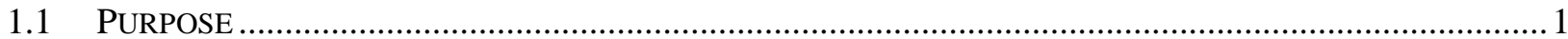

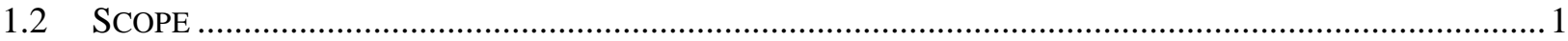

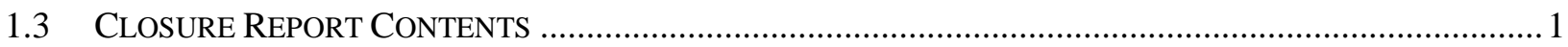

1.3.1 Applicable Programmatic Plans and Documents ............................................................ 4

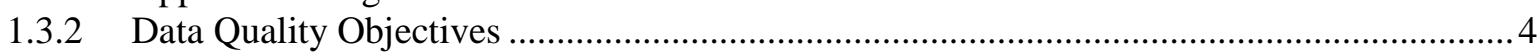

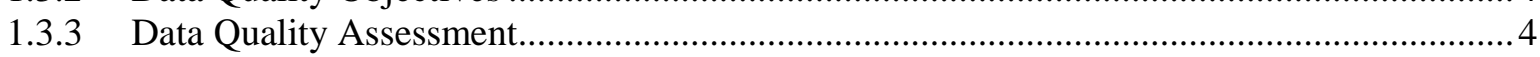

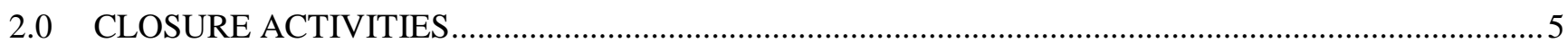

2.1 DESCRIPTION OF CORRECTIVE ACTION ACTIVITIES …............................................................. 5

2.1.1 Corrective Action Site 12-23-10, U12c.03 Crater (Neptune) ........................................... 6

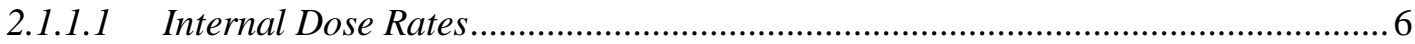

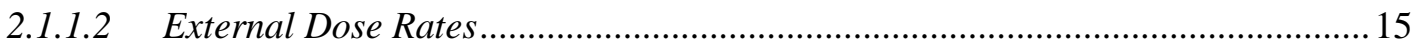

2.1.1.3 Total Effective Dose Rates and Use Restriction Boundary Determination........... 17

2.1.2 Corrective Action Site 12-45-01, U12e.05 Crater (Blanca) ............................................... 24

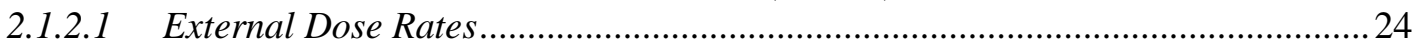

2.1.2.2 Internal Dose Rates........................................................................................ 31

2.1.2.3 Total Effective Dose Rates and Use Restriction Boundary Determination........... 31

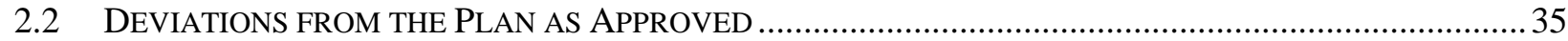

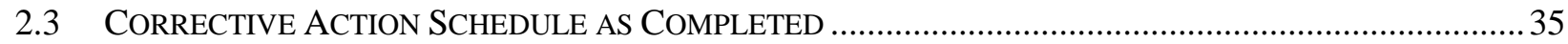

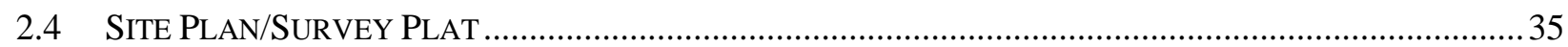

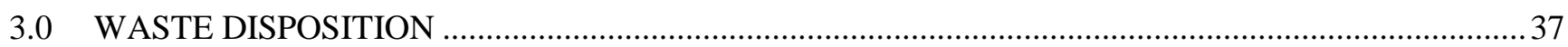

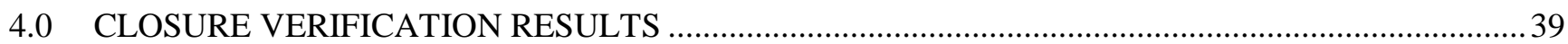

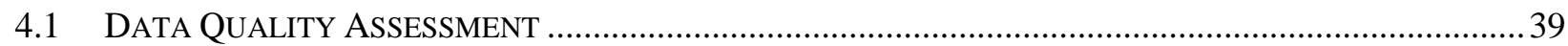

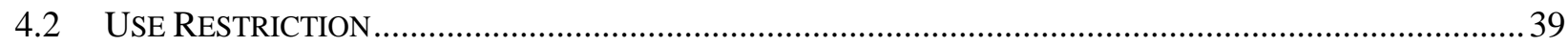

4.2.1 Corrective Action Site 12-23-10, U12c.03 Crater (Neptune)............................................. 39

4.2.2 Corrective Action Site 12-45-01, U12e.05 Crater (Blanca) ................................................ 40

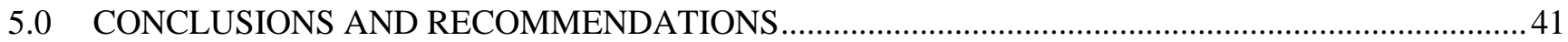

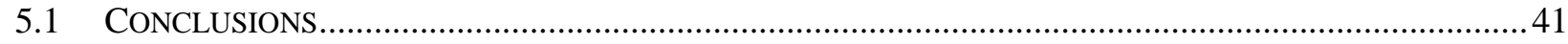

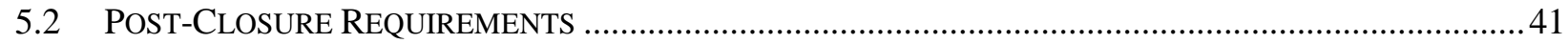

5.2.1 Corrective Action Site 12-23-10, U12c.03 Crater (Neptune)........................................... 41

5.2.2 Corrective Action Site 12-45-01, U12e.05 Crater (Blanca) ............................................. 41

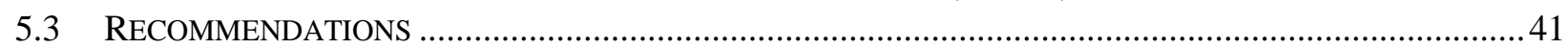

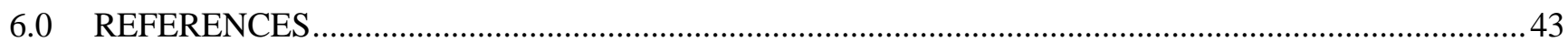

LIBRARY DISTRIBUTION LIST

\section{LIST OF FIGURES}

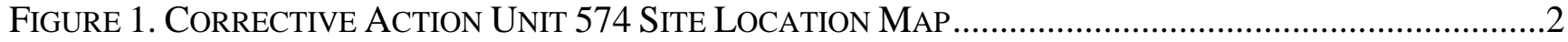

FIGURE 2. CORRECTIVE ACTION SITE LOCATION MAP .......................................................................

FIGURE 3. VIEW FROM RIM OF NEPTUNE CRATER, 05/12/2011 ....................................................7 


\section{TABLE OF CONTENTS (continued)}

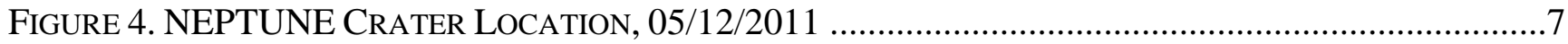

FigURE 5. CORRECTIVE ACTION UNIT 551 SOIL SAMPLE LOCATIONS AND USE RESTRICTION

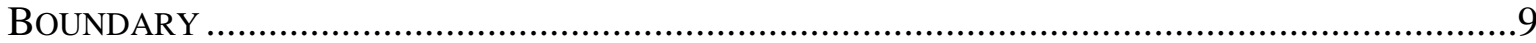

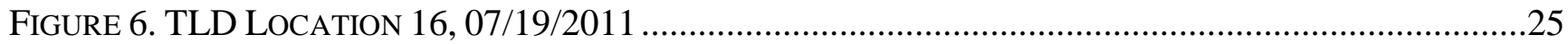

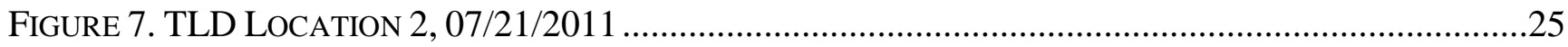

Figure 8. BLANCA Total EFFeCtive Dose RATES AND AdMINISTRATIVE Use Restriction BOUNDARY

\section{LIST OF TABLES}

TABLE 1. Residual RADiOACTIVE MATERIAL GUIDELINES DERIVED FOR NEPTUNE

TABLE 2. INTERNAL DOSE RATES FOR NEPTUNE USING CORRECTIVE ACTION UNIT 551 SOIL

SAMPLE DATA 11

TABLE 3. INTERNAL DOSE RATES FOR NEPTUNE USING CORRELATED 1994 FLYOVER DATA . .14

TABle 4. EXTERNAL DOSE RATES FOR NEPTUNE USING CORRELATED 1994 FLyOVER DATA.............16

TABle 5. Total EfFECTIVE Dose RATES FOR NEPTUNE AT CAU 551 SOIL SAMPLE LOCATIONS .......18

TABle 6. Total EFFEctive Dose RATEs For NEPTUNE USING CORRELATED 1994 FLyOVER

DATA, BASED ON THE INDUSTRIAL AREA EXPOSURE SCENARIO .22

TABle 7. Total EFFECTIVE Dose RATES FOR NEPTUNE USING CORRELATED 1994 FlyOVER DATA, BASED ON THE REMOTE WORK AREA EXPOSURE SCENARIO .22

TABle 8. Total EFFEctive Dose RATES FOR NEPTUNE USING CORRELATED 1994 Flyover DATA, BASED on THE OCCASIONAL USE AREA EXPOSURE SCENARIO ...............................23

TABLE 9. EXTERnAl Dose RATES FOR BLANCA USING CORRELATED 1994 FLyOVER DATA...............29

TABle 10. Thermoluminescent Dosimeter EXTERnAl Dose RATE RESUltS FOR BLANCA ...........29

TABLE 11. INTERNAL DOSE RATES FOR BLANCA USING RIDP DATA. 32

TABle 12. TOTAL EFFECTIVE DOSE RATES AT THERMOLUMINESCENT DOSIMETER LOCATIONS FOR BLANCA .33

TABle 13. Projected Total EfFEctive Dose RAtes For BLANCA Using Correlated 1994 FLYOVER DATA 34

TABle 14. Corrective ACtion Unit 574 Closure ACtivities SCHEdulE 35

TABle 15. ThermoluminesCENT DOSIMETER PRECISION 39

\section{APPENDICES}

Appendix A. DATa Quality OBJectives

APPENDIX B. USE RESTRICTION DOCUMENTATION

APPENDIX C. RIDP DATA EVALUATION AND VERIFICATION WHITE PAPER 


\section{ACRONYMS AND ABBREVIATIONS}

\begin{tabular}{|c|c|}
\hline Am & americium \\
\hline BMP & best management practice \\
\hline CAS & Corrective Action Site \\
\hline CAU & Corrective Action Unit \\
\hline cps & count(s) per second \\
\hline CR & Closure Report \\
\hline DQO & data quality objective \\
\hline FAL & final action level \\
\hline FFACO & Federal Facility Agreement and Consent Order \\
\hline$\mu \mathrm{R} / \mathrm{hr}$ & microroentgen(s) per hour \\
\hline $\mathrm{mrem} / \mathrm{yr}$ & millirem(s) per year \\
\hline NDEP & Nevada Division of Environmental Protection \\
\hline NNSA/NSO & $\begin{array}{l}\text { U.S. Department of Energy, National Nuclear Security Administration } \\
\text { Nevada Site Office }\end{array}$ \\
\hline NNSS & Nevada National Security Site \\
\hline NSTec & National Security Technologies, LLC \\
\hline $\mathrm{pCi} / \mathrm{g}$ & picocurie(s) per gram \\
\hline $\mathrm{Pu}$ & plutonium \\
\hline RIDP & Radionuclide Inventory and Distribution Program \\
\hline RRMG & Residual Radioactive Material Guideline \\
\hline SAFER & Streamlined Approach for Environmental Restoration \\
\hline TED & total effective dose \\
\hline TLD & thermoluminescent dosimeter \\
\hline UCL & upper confidence limit \\
\hline UR & use restriction \\
\hline
\end{tabular}


CAU 574 Closure Report

Section: Acronyms and Abbreviations

Revision: 0

Date: April 2012

\section{THIS PAGE INTENTIONALLY LEFT BLANK}




\section{EXECUTIVE SUMMARY}

Corrective Action Unit (CAU) 574 is identified in the Federal Facility Agreement and Consent Order (FFACO) as "Neptune" and consists of the following two Corrective Action Sites (CASs), located in Area 12 of the Nevada National Security Site:

- CAS 12-23-10, U12c.03 Crater (Neptune)

- CAS 12-45-01, U12e.05 Crater (Blanca)

This Closure Report presents information supporting closure of CAU 574 according to the FFACO (FFACO, 1996 [as amended March 2010]) and the Streamlined Approach for Environmental Restoration Plan for CAU 574 (U.S. Department of Energy, National Nuclear Security Administration Nevada Site Office [NNSA/NSO], 2011).

The following activities were performed to support closure of CAU 574:

- In situ external dose rate measurements were collected using thermoluminescent dosimeters at CAS 12-45-01, U12e.05 Crater (Blanca).

- Total effective dose rates were determined at both sites by summing the internal and external dose rate components.

- A use restriction (UR) was implemented at CAS 12-23-10, U12c.03 Crater (Neptune). Areas that exceed the final action level (FAL) of 25 millirems per year (mrem/yr) based on the Occasional Use Area exposure scenario are within the existing use restricted area for CAU 551. The 25-mrem/yr FAL is not exceeded outside the existing CAU 551 UR for any of the exposure scenarios (Industrial Area, Remote Work Area, and Occasional Use Area). Therefore, the existing UR for CAU 551 is sufficient to bound contamination that exceeds the FAL.

- An administrative UR was implemented at CAS 12-45-01, U12e.05 Crater (Blanca) as a best management practice (BMP). The 25-mrem/yr FAL was not exceeded for the Remote Work Area or Occasional Use Area exposure scenarios; therefore, a UR is not required. However, because the 25-mrem/yr FAL was exceeded for the Industrial Area exposure scenario, an administrative UR was established as a BMP.

UR documentation is included as Appendix B. The UR at CAS 12-23-10, U12c.03 Crater (Neptune), is within the existing UR for CAU 551. Additional postings were not installed, and annual post-closure inspections will be performed in conjunction with the inspections performed for CAU 551. At CAS 12-45-01, U12e.05 Crater (Blanca), the administrative UR does not require postings or inspections.

NNSA/NSO requests the following:

- A Notice of Completion from the Nevada Division of Environmental Protection to NNSA/NSO for closure of CAU 574

- The transfer of CAU 574 from Appendix III to Appendix IV, Closed Corrective Action Units, of the FFACO 
Revision: 0

Date: April 2012

THIS PAGE INTENTIONALLY LEFT BLANK 


\subsection{INTRODUCTION}

This Closure Report (CR) documents closure activities for Corrective Action Unit (CAU) 574, "Neptune," according to the Federal Facility Agreement and Consent Order (FFACO, 1996 [as amended March 2010]). CAU 574 consists of the following two Corrective Action Sites (CASs) located in Area 12 of the Nevada National Security Site (NNSS) (Figures 1 and 2):

- CAS 12-23-10, U12c.03 Crater (Neptune) (referred to as NEPTUNE in this document)

- CAS 12-45-01, U12e.05 Crater (Blanca) (referred to as BLANCA in this document)

\subsection{Purpose}

This CR provides justification for closure of CAU 574 without further corrective action based on implementation of the Streamlined Approach for Environmental Restoration (SAFER) Plan for CAU 574 (U.S. Department of Energy, National Nuclear Security Administration Nevada Site Office [NNSA/NSO], 2011). The SAFER Plan provides information relating to site history as well as the scope and planning of the investigation. This CR provides a summary of completed investigation and closure activities, documentation supporting the completed corrective actions, and confirmation that closure objectives were met.

\subsection{SCOPE}

The following activities were performed to support closure of CAU 574:

- In situ external dose rate measurements were collected at BLANCA using thermoluminescent dosimeters (TLDs).

- Total effective dose (TED) rates were determined at both sites by summing the internal and external dose rate components.

- A use restriction (UR) was implemented at NEPTUNE.

- An administrative UR was implemented at BLANCA as a best management practice (BMP).

\subsection{Closure Report Contents}

This CR includes the following sections:

- Section 1.0: Introduction

- Section 2.0: Closure Activities

- Section 3.0: Waste Disposition

- Section 4.0: Closure Verification Results

- Section 5.0: Conclusions and Recommendations

- Section 6.0: References

- Appendix A: Data Quality Objectives

- Appendix B: Use Restriction Documentation

- Appendix C: RIDP Data Evaluation and Verification White Paper

- Library Distribution List 
Date: April 2012

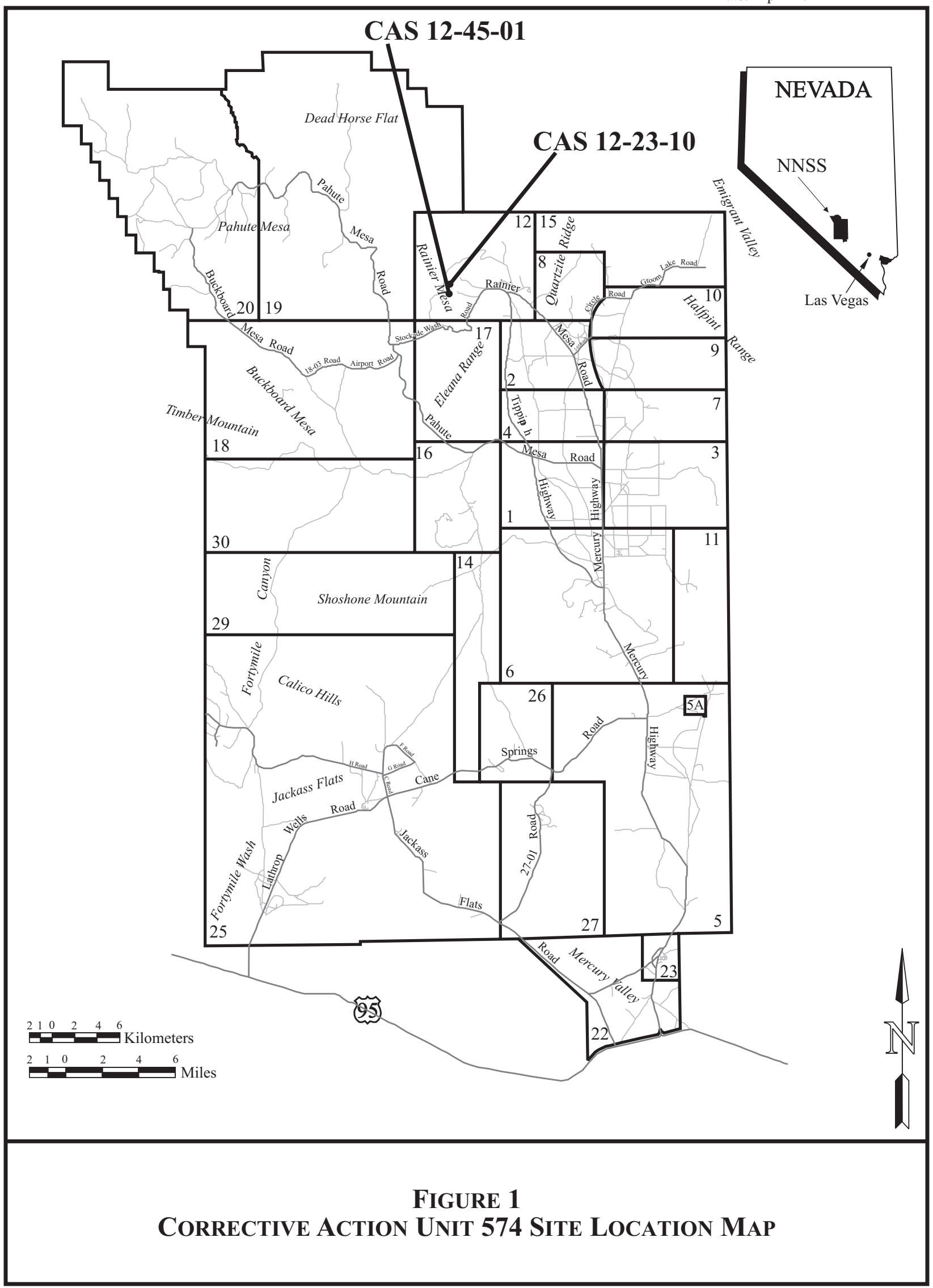




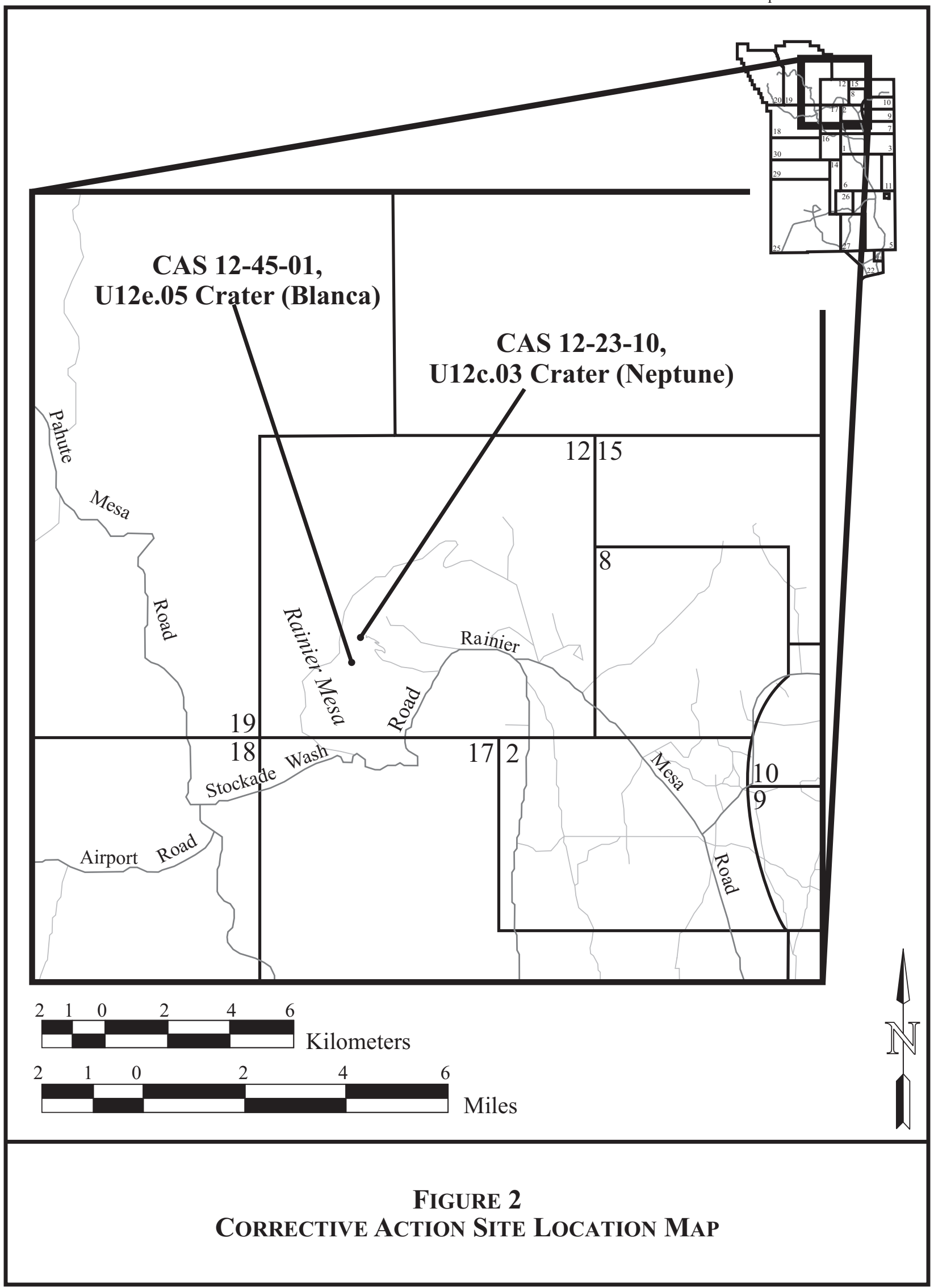




\subsubsection{Applicable Programmatic Plans and Documents}

Investigation and closure activities were performed in accordance with the following documents:

- $\quad$ SAFER Plan for CAU 574 (NNSA/NSO, 2011)

- $\quad$ FFACO (1996, as amended March 2010)

\subsubsection{Data Quality Objectives}

Data quality objectives (DQOs) were developed for CAU 574 in the SAFER Plan (NNSA/NSO, 2011) and are included as Appendix A of this report. The DQOs were developed to identify the informational inputs and data needs to resolve the problem statement. Based on historical documentation, personnel interviews, site process knowledge, site visits, photographs, field screening, analytical results, the results of the DQO process, and an evaluation of corrective action alternatives, closure in place with administrative controls was the expected closure strategy for CAU 574. It was determined that previously collected data would be evaluated to resolve the decision statements and new data would be collected to verify the adequacy of existing information, affirm the chosen corrective action, provide sufficient data to implement the corrective action, and confirm that closure objectives were met. Data collected during the SAFER process included in situ external dose rate measurements using TLDs at BLANCA.

\subsubsection{Data Quality Assessment}

The data quality assessment is presented in Section 4.1. The TLD data collected met the data quality requirements. 


\subsection{CLOSURE ACTIVITIES}

This section summarizes the activities completed for CAU 574, deviations from the SAFER Plan, and the schedule of completed activities.

\subsection{Description of CoRrective ACTiOn ACtivities}

The final action level (FAL) for CAU 574 is a TED of 25 millirems per year (mrem/yr) based on the Occasional Use Area exposure scenario. The extent of contamination that exceeds the FAL is determined by calculating TED. TED is the sum of the internal and external dose components and is a function of the time a receptor is present at the site and exposed to contamination. The Occasional Use Area exposure scenario is the current scenario for the CAU 574 sites, and this scenario is not expected to change in the future. The CAU 574 sites are located in very remote areas on steep, rocky terrain in a Nuclear and High Explosive Test land use zone. The Occasional Use Area exposure scenario assumes occasional activities at a site and exposure to workers who are not assigned to the area. It assumes workers do not regularly visit but may occasionally use the site for short-term activities. A worker under this scenario is on site for up to 80 hours per year for 5 years. TED calculated using this exposure scenario is the maximum dose a worker receives during 80 hours of annual exposure to contamination. There is no anticipated future use of the CAU 574 sites; therefore, Occasional Use (80 hours per year for 5 years) is conservative. Areas in which workers are expected to receive a dose of at least $25 \mathrm{mrem} / \mathrm{yr}$ based on the Occasional Use Area exposure scenario are closed in place with a UR.

TED is also calculated based on the Remote Work Area and Industrial Area exposure scenarios. Although these scenarios are not expected to occur at the CAU 574 sites, they are evaluated based on the slight possibility that use of the area becomes more intensive.

The Remote Work Area exposure scenario assumes non-continuous activities and exposure to workers during a portion of an average workday. It assumes workers regularly visit but do not spend an entire workday at the site. A worker under this scenario is on site for up to 336 hours per year for 25 years. TED calculated using this exposure scenario is the maximum dose a worker receives during 336 hours of annual exposure to contamination.

The Industrial Area exposure scenario assumes continuous industrial use of a site and daily exposure to workers during an average workday. It assumes the site is a regularly assigned work area for a worker for an entire career (225 days per year, 10 hours per day, for 25 years). TED calculated using this exposure scenario is the maximum dose a worker receives during 2,250 hours of annual exposure to contamination.

Areas in which workers are expected to receive a dose of at least $25 \mathrm{mrem} / \mathrm{yr}$ based on the Remote Work Area or Industrial Area exposure scenarios are closed in place with an administrative UR. Administrative URs are implemented as a BMP to restrict future activities that would result in a site worker exceeding the exposure time assumed under the current exposure scenario (Occasional Use Area). Any proposed activity within an administrative UR that would change the current exposure scenario based on a more intensive use of the site would require Nevada Division of Environmental Protection (NDEP) approval.

The following sections describe the investigation and closure activities completed for CAU 574. 


\subsubsection{Corrective Action Site 12-23-10, U12c.03 Crater (Neptune)}

NEPTUNE is located on a 30-degree slope on the side of Rainier Mesa in Area 12 of the NNSS. The primary contaminants are plutonium $(\mathrm{Pu})$ and americium $(\mathrm{Am})$, which contribute to the internal dose component of TED (NNSA/NSO, 2011). Since the NEPTUNE detonation resulted in a small yield, some fission products are also present that may contribute to external dose.

Access to and use of the site is limited due to the remote location, rough and rocky terrain, and steep slope. Photographs of the site are provided in Figures 3 and 4. The site is also controlled as a Contamination Area, and use of the area is restricted by the UR implemented during closure of CAU 551. Figure 5 shows the location of the existing UR for CAU 551 in relation to NEPTUNE.

A large body of historical information is available for NEPTUNE, including 1994 flyover data, CAU 551 soil sample data, and in situ gamma spectroscopy data collected under the Radionuclide Inventory and Distribution Program (RIDP). Existing characterization data were used to delineate the extent of contamination that exceeds the FAL to define a UR at this site. Collection of additional data was not required for NEPTUNE.

\subsubsection{Internal Dose Rates}

Internal dose rates at NEPTUNE were determined using soil sample data collected for CAU 551. The CAU 551 soil sample locations are shown on Figure 5 (NNSA/NSO, 2006). The samples collected along the wash to the southeast of the site show that there are elevated concentrations of Am and Pu along this drainage path that were not detected by the 1994 flyover. Results of soil samples collected along the road to the southeast of the existing UR for CAU 551 were also analyzed.

CAU 551 data were compared to the Residual Radioactive Material Guidelines (RRMGs) provided in Table 1 using the sum of the fractions approach to determine the total internal dose. The RRMGs were determined using the Residual Radioactive computer code, as discussed in the SAFER Plan (NNSA/NSO, 2011). The RRMGs are the concentrations of individual radionuclides in soil that would cause a receptor to receive an internal dose equal to the FAL. Table 2 provides the internal dose rates calculated based on CAU 551 soil sample data for each of the three exposure scenarios. At locations where samples were collected at multiple depths, the average concentration was used to determine dose.

Soil samples were not collected to the northwest and southwest of the existing UR for CAU 551 where Am-241 was detected by the 1994 flyover. In these areas, correlated 1994 flyover data from across the NNSS were used to calculate internal dose. The 1994 flyover results are shown in Figure 5, and the areas where Am was detected are labeled "Am Bin A-B," "Am Bin B-C," and "Am Bin C-D." A bin is defined as the group of measurements collected in the area between two isopleths. For example, Am Bin A-B is the range of values between Isopleths A and B, where an Am count rate of 50-100 counts per second (cps) was detected. The RIDP data collected from all areas of the NNSS within each Am bin were grouped, and an average was obtained and converted to units of mrem/yr for each of the three exposure scenarios. The method used to convert RIDP data and the correlation of RIDP to 1994 flyover data are described in Radionuclide Inventory Distribution Project Data Evaluation and Verification White Paper (National Security Technologies, LLC [NSTec], 2008), which is included as Appendix C of this document. Table 3 provides the 95-percent upper confidence limit (UCL) of the average internal dose calculated for each Am bin and for each exposure scenario. 


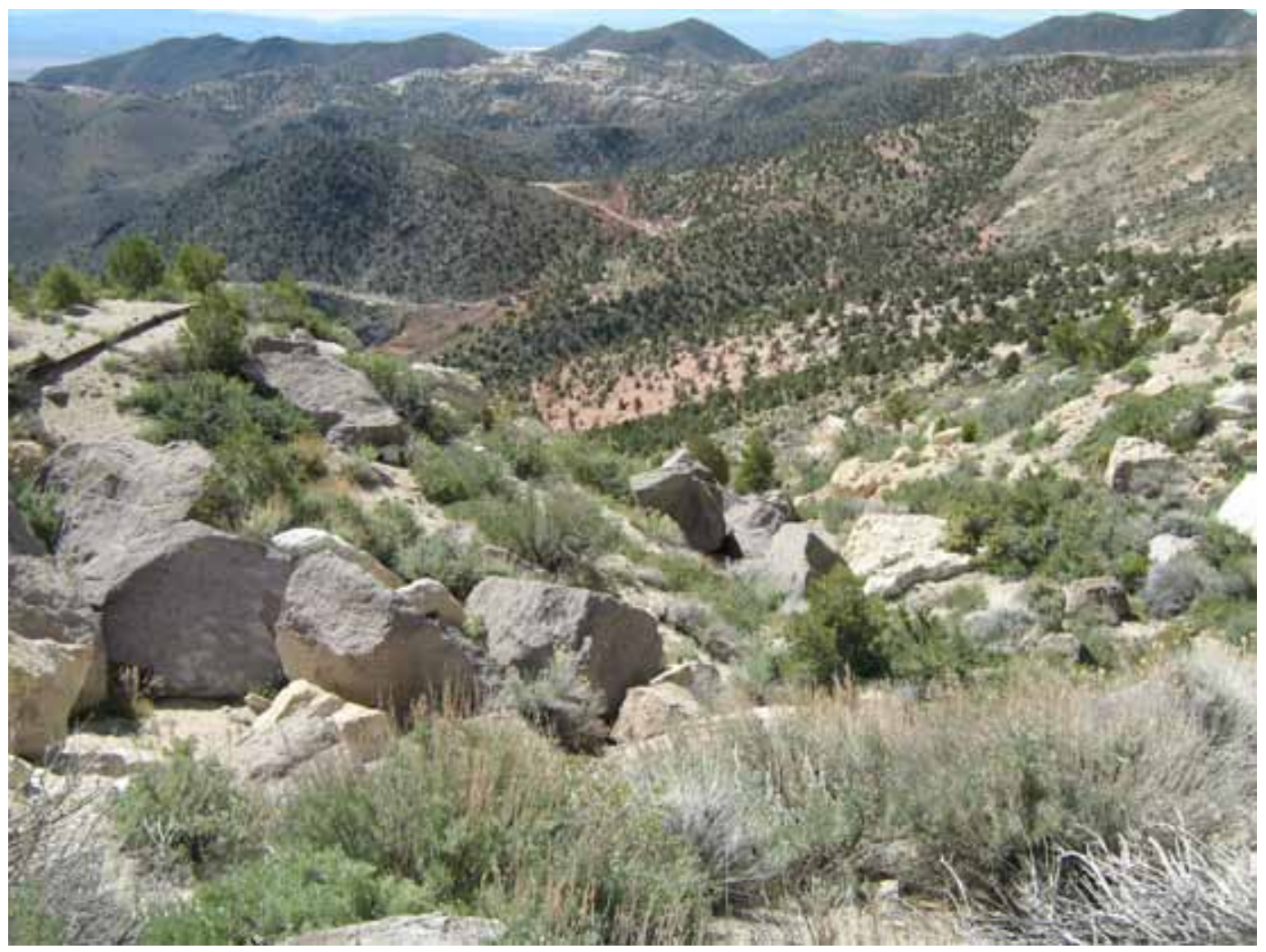

FIGURE 3. VIEW FROM RIM OF NEPTUNE CRATER, 05/12/2011

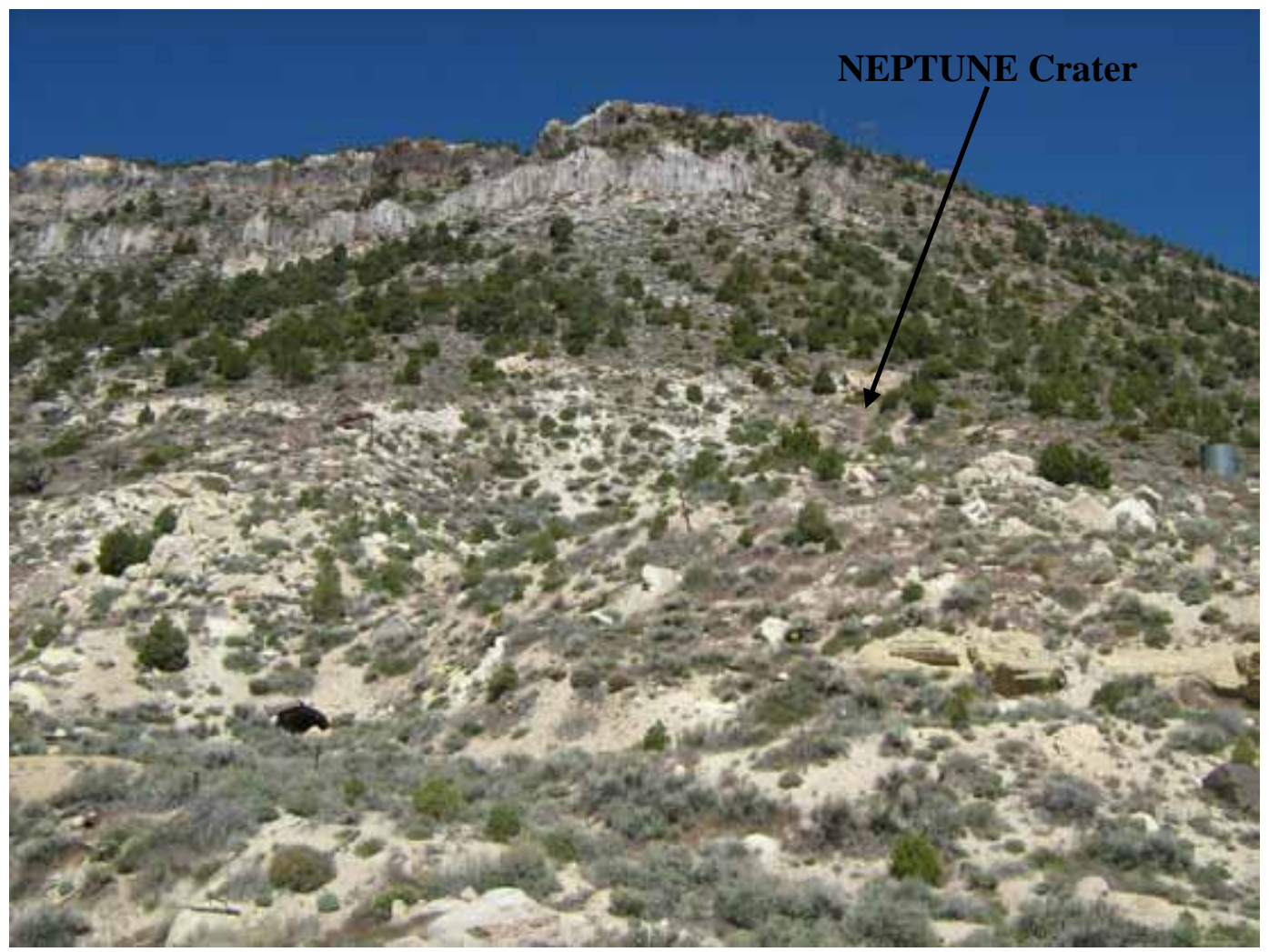

FIGURE 4. NEPTUNE CRATER LOCATION, 05/12/2011 
Revision: 0

Date: April 2012

THIS PAGE INTENTIONALLY LEFT BLANK 


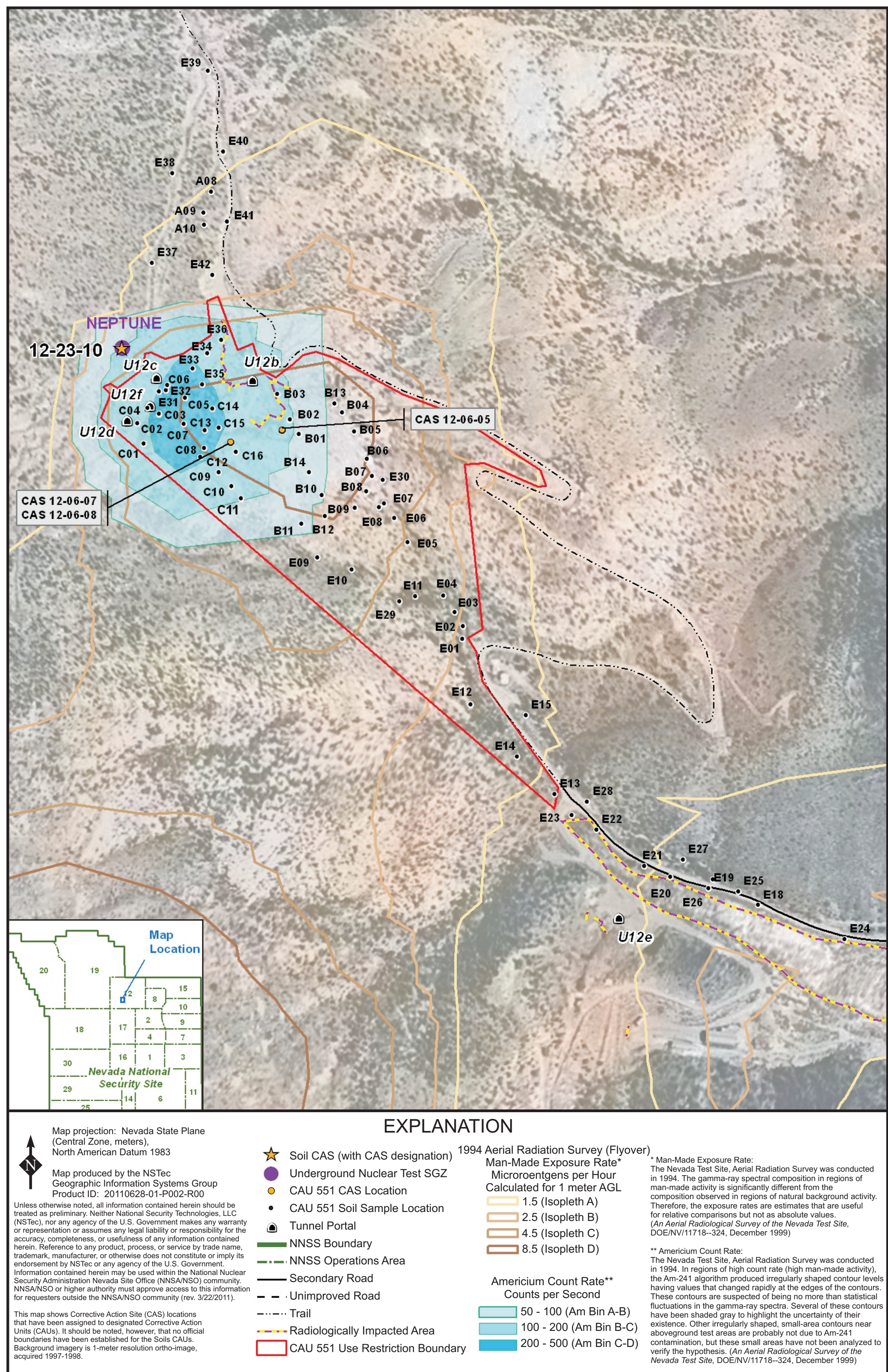

FIGURE 5

CORRECTIVE ACTION UNIT 551 SOIL SAMPLE LoCations AND USE RESTRICTION BOUNDARY 
CAU 574 Closure Report

Section: Closure Activities

Date: April 2012

THIS PAGE INTENTIONALLY LEFT BLANK 
TABLE 1. ResiduAl RADIOACTIVE MATERIAL GUIDELINES DERIVED FOR NEPTUNE

\begin{tabular}{|c|c|c|c||}
\hline \multirow{2}{*}{ RADIONUCLIDE } & \multicolumn{2}{|c|}{ RESIDUAL RADIOACTIVE MATERIAL GUIDELINE (pCi/g) } \\
\cline { 2 - 4 } & INDUSTRIAL & REMOTE WORK & OCCASIONAL USE \\
\hline \hline americium-241 & 350 & 1,334 & 5,611 \\
\hline cobalt-60 & 98,590 & 600,300 & $2,525,000$ \\
\hline cesium-137 & 53,650 & 355,900 & $1,497,000$ \\
\hline europium-152 & 323,200 & $1,615,000$ & $6,793,000$ \\
\hline europium-154 & 228,800 & $1,172,000$ & $4,928,000$ \\
\hline europium-155 & $1,502,000$ & $7,835,000$ & $32,950,000$ \\
\hline plutonium-238 & 398 & 1,516 & 6,378 \\
\hline plutonium-239 & 360 & 1,376 & 5,788 \\
\hline plutonium-240 & 360 & 1,376 & 5,788 \\
\hline strontium-90 & 16,410 & 99,480 & 418,400 \\
\hline
\end{tabular}

$\mathrm{pCi} / \mathrm{g}=$ picocurie(s) per gram

TABLE 2. INTERNAL DOSE RATES FOR NEPTUNE USING CorRective ACTION UnIT 551 SoIL SAMPLE DATA

\begin{tabular}{|c|c|c|c|}
\hline \multirow{2}{*}{ SAMPLE LOCATION } & \multicolumn{3}{|c|}{ INTERNAL DOSE RATE (mrem/yr) } \\
\cline { 2 - 4 } & INDUSTRIAL & REMOTE WORK & OCCASIONAL USE \\
\hline \hline A08 & 2.06 & 0.54 & 0.13 \\
\hline A09 & 0.75 & 0.20 & 0.05 \\
\hline A10 & 1.13 & 0.29 & 0.07 \\
\hline B01 & 4.04 & 1.06 & 0.25 \\
\hline B02 & 54.87 & 14.35 & 3.41 \\
\hline B03 & 17.14 & 4.48 & 1.06 \\
\hline B04 & 18.96 & 4.96 & 1.18 \\
\hline B05 & 54.48 & 14.26 & 3.39 \\
\hline B06 & 47.19 & 12.35 & 2.94 \\
\hline B07 & 21.81 & 5.71 & 1.36 \\
\hline B08 & 5.81 & 1.52 & 0.36 \\
\hline B09 & 9.33 & 2.44 & 0.58 \\
\hline B10 & 30.70 & 8.04 & 1.91 \\
\hline B11 & 9.61 & 2.52 & 0.60 \\
\hline B12 & 2.35 & 0.61 & 0.15 \\
\hline B13 & 19.10 & 5.00 & 1.19 \\
\hline B14 & 136.05 & 35.61 & 8.47 \\
\hline C01 & 0.29 & 0.08 & 0.02 \\
\hline C02 & 32.95 & 8.62 & 2.05 \\
\hline C03 & 323.29 & 84.60 & 20.11 \\
\hline & & & \\
\hline & & & \\
\hline & & & \\
\hline & & & \\
\hline & & & \\
\hline
\end{tabular}


TABLE 2. INTERNAL DOSE RATES FOR NEPTUNE USING CoRrective ACTION Unit 551 SoIL SAMPLE DATA (CONTINUED)

\begin{tabular}{|c|c|c|c|}
\hline \multirow{2}{*}{ SAMPLE LOCATION } & \multicolumn{3}{|c|}{ INTERNAL DOSE RATE (mrem/yr) } \\
\hline & INDUSTRIAL & REMOTE WORK & OCCASIONAL USE \\
\hline $\mathrm{C} 04$ & 536.60 & 140.42 & 33.38 \\
\hline $\mathrm{C} 05$ & 251.04 & 65.72 & 15.62 \\
\hline $\mathrm{C} 06$ & 71.56 & 18.74 & 4.45 \\
\hline $\mathrm{C} 07$ & 124.40 & 32.57 & 7.74 \\
\hline C08 & 16.91 & 4.43 & 1.05 \\
\hline C09 & 303.13 & 79.37 & 18.87 \\
\hline C10 & 473.88 & 124.08 & 29.50 \\
\hline C11 & 118.83 & 31.11 & 7.40 \\
\hline C12 & 171.98 & 45.03 & 10.70 \\
\hline C13 & 165.92 & 43.44 & 10.33 \\
\hline $\mathrm{C} 14$ & 130.89 & 34.26 & 8.15 \\
\hline $\mathrm{C} 15$ & 82.96 & 21.71 & 5.16 \\
\hline $\mathrm{C} 16$ & 6.11 & 1.60 & 0.38 \\
\hline E01 & 3.50 & 0.92 & 0.22 \\
\hline E02 & 0.56 & 0.15 & 0.04 \\
\hline E03 & 18.90 & 4.95 & 1.18 \\
\hline E04 & 13.77 & 3.60 & 0.86 \\
\hline E05 & 16.06 & 4.21 & 1.00 \\
\hline E06 & 28.98 & 7.59 & 1.80 \\
\hline E07 & 31.62 & 8.28 & 1.97 \\
\hline E08 & 0.11 & 0.03 & 0.01 \\
\hline E09 & 4.19 & 1.10 & 0.26 \\
\hline E10 & 29.77 & 7.80 & 1.85 \\
\hline E11 & 1.55 & 0.41 & 0.10 \\
\hline E12 & 0.08 & 0.02 & 0.01 \\
\hline E13 & 13.56 & 3.55 & 0.84 \\
\hline E14 & 20.04 & 5.25 & 1.25 \\
\hline E15 & 0.05 & 0.01 & 0.00 \\
\hline E18 & 0.03 & 0.01 & 0.00 \\
\hline E19 & 0.13 & 0.03 & 0.01 \\
\hline E20 & 0.03 & 0.01 & 0.00 \\
\hline E21 & 0.02 & 0.01 & 0.00 \\
\hline E22 & 0.05 & 0.01 & 0.00 \\
\hline E23 & 0.12 & 0.03 & 0.01 \\
\hline E24 & 0.03 & 0.01 & 0.00 \\
\hline E25 & 0.10 & 0.03 & 0.01 \\
\hline
\end{tabular}


TABLE 2. INTERNAL DOSE RATES FOR NEPTUNE USING CORRECTIVE ACTION UNIT 551 SOIL SAMPLE DATA (CONTINUED)

\begin{tabular}{|c|c|c|c|}
\hline \multirow{2}{*}{ SAMPLE LOCATION } & \multicolumn{3}{|c|}{ INTERNAL DOSE RATE (mrem/yr) } \\
\cline { 2 - 4 } & INDUSTRIAL & REMOTE WORK & OCCASIONAL USE \\
\hline E26 & 0.39 & 0.10 & 0.02 \\
\hline E27 & 0.25 & 0.06 & 0.02 \\
\hline E28 & 0.10 & 0.03 & 0.01 \\
\hline E29 & 0.15 & 0.04 & 0.01 \\
\hline E30 & 15.07 & 3.94 & 0.94 \\
\hline E31 & 137.04 & 35.87 & 8.53 \\
\hline E32 & 103.04 & 26.98 & 6.41 \\
\hline E33 & 19.31 & 5.06 & 1.20 \\
\hline E34 & 130.52 & 34.16 & 8.12 \\
\hline E35 & 24.64 & 6.45 & 1.53 \\
\hline E36 & 3.12 & 0.82 & 0.19 \\
\hline E37 & 0.04 & 0.01 & 0.00 \\
\hline E38 & 0.39 & 0.10 & 0.02 \\
\hline E39 & 0.12 & 0.03 & 0.01 \\
\hline E40 & 0.01 & 0.00 & 0.00 \\
\hline E41 & 0.12 & 0.03 & 0.01 \\
\hline E42 & 0.33 & 0.09 & 0.02 \\
\hline
\end{tabular}

mrem/yr = millirem(s) per year 
TABLE 3. INTERNAL DOSE RATES FOR NEPTUNE USING CORRELATED 1994 FLyOVER DATA

\begin{tabular}{|c|c|c|c|c|c|c|c|c|}
\hline \multirow{2}{*}{$\begin{array}{c}1994 \\
\text { FLYOVER } \\
\text { AMERICIUM } \\
\text { BIN* }\end{array}$} & \multirow{2}{*}{$\begin{array}{c}1994 \\
\text { FLYOVER } \\
\text { AMERICIUM } \\
\text { COUNT } \\
\text { RATE (cPs) }\end{array}$} & \multirow{2}{*}{$\begin{array}{c}\text { NUMBER OF } \\
\text { RIDP } \\
\text { MEASUREMENTS } \\
\text { COLLECTED }\end{array}$} & \multicolumn{2}{|c|}{ INDUSTRIAL } & \multicolumn{2}{|c|}{ REMOTE WORK } & \multicolumn{2}{|c|}{ OCCASIONAL USE } \\
\hline & & & $\begin{array}{c}\text { AVERAGE } \\
\text { INTERNAL } \\
\text { DOSE RATE } \\
\text { (mrem/yr) }\end{array}$ & $\begin{array}{c}\text { 95\% UCL } \\
\text { INTERNAL } \\
\text { DOSE RATE } \\
\text { (mrem/yr) }\end{array}$ & $\begin{array}{c}\text { AVERAGE } \\
\text { INTERNAL } \\
\text { DOSE RATE } \\
\text { (mrem/yr) }\end{array}$ & $\begin{array}{c}\text { 95\% UCL } \\
\text { INTERNAL } \\
\text { DOSE RATE } \\
\text { (mrem/yr) }\end{array}$ & $\begin{array}{c}\text { AVERAGE } \\
\text { INTERNAL } \\
\text { DOSE RATE } \\
\text { (mrem/yr) }\end{array}$ & $\begin{array}{c}\text { 95\% UCL } \\
\text { INTERNAL } \\
\text { DOSE RATE } \\
\text { (mrem/yr) }\end{array}$ \\
\hline N/A & $0-50$ & 3,406 & 1.19 & 1.35 & 0.31 & 0.35 & 0.07 & 0.08 \\
\hline Am Bin A-B & $50-100$ & 105 & 3.56 & 4.68 & 0.93 & 1.23 & 0.22 & 0.29 \\
\hline Am Bin B-C & $100-200$ & 87 & 5.20 & 6.52 & 1.36 & 1.71 & 0.32 & 0.41 \\
\hline Am Bin C-D & $200-500$ & 69 & 29.18 & 46.07 & 7.64 & 12.07 & 1.82 & 2.87 \\
\hline
\end{tabular}

cps = count(s) per second

$\mathrm{mrem} / \mathrm{yr}=$ millirem(s) per year

$\mathrm{UCL}=$ upper confidence limit

* The 1994 flyover americium bins are identified in Figure 5. 


\subsubsection{External Dose Rates}

External dose rates at NEPTUNE were conservatively determined using correlated 1994 flyover data from across the NNSS. The 1994 flyover results are shown in Figure 5, and the man-made exposure rate isopleths are labeled Isopleth A through D. The group of measurements collected in an area between two isopleths is defined as a bin. For example, Man-Made Bin A-B includes the range of values between Isopleths $A$ and $B$, where a man-made exposure rate of 1.5-2.5 microroentgens per hour $(\mu \mathrm{R} / \mathrm{hr})$ was detected.

The RIDP data collected from all areas of the NNSS within each man-made bin were grouped. An average was obtained for each group of data and converted to units of mrem/yr for each of the three exposure scenarios, as described in Radionuclide Inventory Distribution Project Data Evaluation and Verification White Paper (NSTec, 2008), which is included as Appendix C of this document.

Table 4 provides the external dose rates calculated for each man-made exposure rate bin. The 95-percent UCL of the average external dose rate is listed for each exposure scenario. 
Date: April 2012

TABLE 4. EXTERnAl DOSE RATES FOR NEPTUNE USING CORRELATED 1994 FLyOVER DATA

\begin{tabular}{|c|c|c|c|c|c|c|c|c|}
\hline \multirow[b]{2}{*}{$\begin{array}{c}1994 \\
\text { FLYOVER } \\
\text { MAN-MADE } \\
\text { BIN* }\end{array}$} & \multirow{2}{*}{$\begin{array}{c}1994 \\
\text { FLYOVER } \\
\text { MAN-MADE } \\
\text { EXPOSURE } \\
\text { RATE }(\boldsymbol{\mu R} / \mathbf{h r})\end{array}$} & \multirow[b]{2}{*}{$\begin{array}{c}\text { NUMBER OF } \\
\text { RIDP } \\
\text { MEASUREMENTS } \\
\text { COLLECTED }\end{array}$} & \multicolumn{2}{|c|}{ INDUSTRIAL } & \multicolumn{2}{|c|}{ REMOTE WORK } & \multicolumn{2}{|c|}{ OCCASIONAL USE } \\
\hline & & & $\begin{array}{c}\text { AVERAGE } \\
\text { EXTERNAL } \\
\text { DOSE RATE } \\
\text { (mrem/yr) }\end{array}$ & $\begin{array}{c}\text { 95\% UCL } \\
\text { EXTERNAL } \\
\text { DOSE RATE } \\
\text { (mrem/yr) }\end{array}$ & $\begin{array}{c}\text { AVERAGE } \\
\text { EXTERNAL } \\
\text { DOSE RATE } \\
\text { (mrem/yr) }\end{array}$ & $\begin{array}{c}\text { 95\% UCL } \\
\text { EXTERNAL } \\
\text { DOSE RATE } \\
\text { (mrem/yr) }\end{array}$ & $\begin{array}{l}\text { AVERAGE } \\
\text { EXTERNAL } \\
\text { DOSE RATE } \\
\text { (mrem/yr) }\end{array}$ & $\begin{array}{c}\text { 95\% UCL } \\
\text { EXTERNAL } \\
\text { DOSE RATE } \\
\text { (mrem/yr) }\end{array}$ \\
\hline $\mathrm{N} / \mathrm{A}$ & $0-1.5$ & 2,075 & 1.03 & 1.08 & 0.15 & 0.16 & 0.04 & 0.04 \\
\hline $\begin{array}{c}\text { Man-Made } \\
\text { Bin A-B }\end{array}$ & $1.5-2.5$ & 386 & 2.67 & 3.00 & 0.40 & 0.45 & 0.09 & 0.11 \\
\hline $\begin{array}{c}\text { Man-Made } \\
\text { Bin B-C }\end{array}$ & $2.5-4.5$ & 302 & 4.44 & 5.50 & 0.66 & 0.82 & 0.16 & 0.20 \\
\hline $\begin{array}{c}\text { Man-Made } \\
\text { Bin C-D }\end{array}$ & $4.5-8.5$ & 279 & 8.16 & 9.97 & 1.22 & 1.49 & 0.29 & 0.35 \\
\hline $\begin{array}{c}\text { Man-Made } \\
\text { Bin D-E }\end{array}$ & $8.5-15$ & 251 & 14.50 & 16.50 & 2.17 & 2.46 & 0.52 & 0.59 \\
\hline
\end{tabular}

$\mu \mathrm{R} / \mathrm{hr}=$ microroentgen $(\mathrm{s})$ per hour

$\mathrm{mrem} / \mathrm{yr}=\operatorname{millirem}(\mathrm{s})$ per year

UCL = upper confidence limit

* The 1994 flyover man-made bins are identified in Figure 5. 


\subsubsection{Total Effective Dose Rates and Use Restriction Boundary Determination}

TED for NEPTUNE was determined by summing the internal and external dose components. Table 5 lists the TED at each CAU 551 sample location. In this case, internal dose rates were calculated using CAU 551 soil sample data, as listed in Table 2. External dose rates were determined from correlated 1994 flyover data, as listed in Table 4. Results greater than the FAL of $25 \mathrm{mrem} / \mathrm{yr}$ are identified by bold text. Samples collected outside the existing UR for CAU 551 are shaded gray. As shown in Table 5, none of the sample locations outside the existing UR for CAU 551 exceed the 25-mrem/yr FAL for any of the three exposure scenarios (Industrial Area, Remote Work Area, and Occasional Use Area).

To determine TED for NEPTUNE where soil samples were not collected for CAU 551 and where Am-241 was detected by the 1994 flyover, the internal dose rates listed in Table 3 and the external dose rates listed in Table 4 were summed. Table 6 lists the TED for the Industrial Area exposure scenario. The only area that exceeds $25 \mathrm{mrem} / \mathrm{yr}$ based on the Industrial Area exposure scenario is the area where an Am count rate of 200-500 cps (Am Bin C-D) was detected. This area is within the existing UR for CAU 551; therefore, the 25-mrem/yr FAL for the Industrial Area exposure scenario is not exceeded outside the existing UR. Tables 7 and 8 list the TED rates for the Remote Work Area and Occasional Use Area exposure scenarios. The 25-mrem/yr FAL is not exceeded for the Remote Work Area or Occasional Use Area exposure scenarios.

Many of the CAU 551 soil sample results yield higher dose rates than those projected based on correlated 1994 flyover data. Sample locations on the muckpiles were chosen to bias the CAU 551 investigation towards the most likely contaminated areas. Samples were collected at locations with elevated levels of radiation detected during field screening (NNSA/NSO, 2006). This method is expected to inaccurately reflect site conditions and overestimate the actual dose that could be received in an area (Los Alamos Scientific Laboratory, 1971).

At Soils Sub-Project sites, composite soil samples are collected from multiple locations within a sample plot to get a more accurate estimation of dose. Using CAU 551 soil sample data to calculate dose is conservative due to the expected overestimation of the dose. In situ methods are less subject to these errors because the sample size, or measurement field of view, is large relative to an individual soil sample. The large field of view represents a more realistic exposure scenario than soil samples.

Based on both CAU 551 soil sample data and correlated 1994 flyover data, the $25-\mathrm{mrem} / \mathrm{yr}$ FAL is not exceeded outside the existing UR for any of the exposure scenarios (Industrial Area, Remote Work Area, and Occasional Use Area). Therefore, the existing UR for CAU 551 is sufficient to bound contamination that exceeds the FAL at NEPTUNE. Based on the CAU 551 soil sample data, areas within the UR for CAU 551 exceed the 25-mrem/yr FAL based on the Occasional Use Area scenario; therefore, a UR was implemented for NEPTUNE.

The data used to determine the UR boundary are expected to overestimate the dose; however, the collection of more precise data that may allow a reduction in the size of the UR is not beneficial as there is no anticipated future use of the site. In addition, the NEPTUNE UR is within the UR for CAU 551. Therefore, reducing the footprint of the NEPTUNE UR would not result in an overall reduction of the UR footprint in this area. 
TABle 5. Total EfFEctive Dose RATEs for NEPTUNE at CAU 551 SoIL SAMPLE Locations

\begin{tabular}{|c|c|c|c|c|c|c|c|c|c|c|}
\hline \multirow[b]{2}{*}{$\begin{array}{c}\text { CAU } 551 \\
\text { SAMPLE } \\
\text { LOCATION }\end{array}$} & \multirow{2}{*}{$\begin{array}{c}1994 \\
\text { FLYOVER } \\
\text { MAN-MADE } \\
\text { BIN* }\end{array}$} & \multicolumn{3}{|c|}{ INDUSTRIAL } & \multicolumn{3}{|c|}{ REMOTE WORK } & \multicolumn{3}{|c|}{ OCCASIONAL USE } \\
\hline & & $\begin{array}{c}\text { EXTERNAL } \\
\text { DOSE RATE } \\
\text { (mrem/yr) }\end{array}$ & $\begin{array}{c}\text { INTERNAL } \\
\text { DOSE RATE } \\
\text { (mrem/yr) }\end{array}$ & $\begin{array}{c}\text { TOTAL } \\
\text { EFFECTIVE } \\
\text { DosE RATE } \\
\text { (mrem/yr) }\end{array}$ & $\begin{array}{c}\text { EXTERNAL } \\
\text { DOSE RATE } \\
\text { (mrem/yr) }\end{array}$ & $\begin{array}{c}\text { INTERNAL } \\
\text { DOSE RATE } \\
\text { (mrem/yr) }\end{array}$ & $\begin{array}{c}\text { TOTAL } \\
\text { EFFECTIVE } \\
\text { DOSE RATE } \\
\text { (mrem/yr) }\end{array}$ & $\begin{array}{c}\text { EXTERNAL } \\
\text { DOSE RATE } \\
\text { (mrem/yr) }\end{array}$ & $\begin{array}{c}\text { INTERNAL } \\
\text { DOSE RATE } \\
\text { (mrem/yr) }\end{array}$ & $\begin{array}{c}\text { TOTAL } \\
\text { EFFECTIVE } \\
\text { DOSE RATE } \\
\text { (mrem/yr) }\end{array}$ \\
\hline A08 & A-B & 3.00 & 2.06 & 5.06 & 0.45 & 0.54 & 0.99 & 0.11 & 0.13 & 0.24 \\
\hline A09 & A-B & 3.00 & 0.75 & 3.75 & 0.45 & 0.20 & 0.65 & 0.11 & 0.05 & 0.16 \\
\hline A10 & A-B & 3.00 & 1.13 & 4.13 & 0.45 & 0.29 & 0.74 & 0.11 & 0.07 & 0.18 \\
\hline B01 & D-E & 16.50 & 4.04 & 20.54 & 2.46 & 1.06 & 3.52 & 0.59 & 0.25 & 0.84 \\
\hline B02 & D-E & 16.50 & 54.87 & 71.37 & 2.46 & 14.35 & 16.81 & 0.59 & 3.41 & 4.00 \\
\hline B03 & D-E & 16.50 & 17.14 & 33.64 & 2.46 & 4.48 & 6.94 & 0.59 & 1.06 & 1.65 \\
\hline B04 & D-E & 16.50 & 18.96 & 35.46 & 2.46 & 4.96 & 7.42 & 0.59 & 1.18 & 1.77 \\
\hline B05 & D-E & 16.50 & 54.48 & 70.98 & 2.46 & 14.26 & 16.72 & 0.59 & 3.39 & 3.98 \\
\hline B06 & D-E & 16.50 & 47.19 & 63.69 & 2.46 & 12.35 & 14.81 & 0.59 & 2.94 & 3.53 \\
\hline B07 & C-D & 9.97 & 21.81 & 31.78 & 1.49 & 5.71 & 7.20 & 0.35 & 1.36 & 1.71 \\
\hline B08 & C-D & 9.97 & 5.81 & 15.78 & 1.49 & 1.52 & 3.01 & 0.35 & 0.36 & 0.71 \\
\hline B09 & C-D & 9.97 & 9.33 & 19.30 & 1.49 & 2.44 & 3.93 & 0.35 & 0.58 & 0.93 \\
\hline B10 & D-E & 16.50 & 30.70 & 47.20 & 2.46 & 8.04 & 10.50 & 0.59 & 1.91 & 2.50 \\
\hline B11 & C-D & 9.97 & 9.61 & 19.58 & 1.49 & 2.52 & 4.01 & 0.35 & 0.60 & 0.95 \\
\hline B12 & D-E & 16.50 & 2.35 & 18.85 & 2.46 & 0.61 & 3.07 & 0.59 & 0.15 & 0.74 \\
\hline B13 & D-E & 16.50 & 19.10 & 35.60 & 2.46 & 5.00 & 7.46 & 0.59 & 1.19 & 1.78 \\
\hline B14 & D-E & 16.50 & 136.05 & 152.55 & 2.46 & 35.61 & 38.07 & 0.59 & 8.47 & 9.06 \\
\hline C01 & C-D & 9.97 & 0.29 & 10.26 & 1.49 & 0.08 & 1.57 & 0.35 & 0.02 & 0.37 \\
\hline C02 & C-D & 9.97 & 32.95 & 42.92 & 1.49 & 8.62 & 10.11 & 0.35 & 2.05 & 2.40 \\
\hline
\end{tabular}


TABle 5. Total EFFective Dose RATES fOR NEPTUNE AT CAU 551 SoIl SAMPLE Locations (CONTINUED)

\begin{tabular}{|c|c|c|c|c|c|c|c|c|c|c|}
\hline \multirow[b]{2}{*}{$\begin{array}{c}\text { CAU } 551 \\
\text { SAMPLE } \\
\text { LOCATION }\end{array}$} & \multirow{2}{*}{$\begin{array}{c}1994 \\
\text { FLYOVER } \\
\text { MAN-MADE } \\
\text { BIN* }\end{array}$} & \multicolumn{3}{|c|}{ INDUSTRIAL } & \multicolumn{3}{|c|}{ REMOTE WORK } & \multicolumn{3}{|c|}{ OCCASIONAL USE } \\
\hline & & $\begin{array}{c}\text { EXTERNAL } \\
\text { DOSE RATE } \\
\text { (mrem/yr) }\end{array}$ & $\begin{array}{c}\text { INTERNAL } \\
\text { DOSE RATE } \\
\text { (mrem/yr) }\end{array}$ & $\begin{array}{c}\text { TOTAL } \\
\text { EFFECTIVE } \\
\text { DOSE RATE } \\
\text { (mrem/yr) }\end{array}$ & $\begin{array}{c}\text { EXTERNAL } \\
\text { DOSE RATE } \\
\text { (mrem/yr) }\end{array}$ & $\begin{array}{c}\text { INTERNAL } \\
\text { DOSE RATE } \\
\text { (mrem/yr) }\end{array}$ & $\begin{array}{c}\text { TOTAL } \\
\text { EFFECTIVE } \\
\text { DOSE RATE } \\
\text { (mrem/yr) }\end{array}$ & $\begin{array}{c}\text { EXTERNAL } \\
\text { DOSE RATE } \\
\text { (mrem/yr) }\end{array}$ & $\begin{array}{c}\text { INTERNAL } \\
\text { DOSE RATE } \\
\text { (mrem/yr) }\end{array}$ & $\begin{array}{c}\text { TOTAL } \\
\text { EFFECTIVE } \\
\text { DoSE RATE } \\
\text { (mrem/yr) }\end{array}$ \\
\hline C03 & C-D & 9.97 & 323.29 & 333.26 & 1.49 & 84.60 & 86.09 & 0.35 & 20.11 & 20.46 \\
\hline C04 & C-D & 9.97 & 536.60 & 546.57 & 1.49 & 140.42 & 141.91 & 0.35 & 33.38 & 33.73 \\
\hline $\mathrm{C} 05$ & D-E & 16.50 & 251.04 & 267.54 & 2.46 & 65.72 & 68.18 & 0.59 & 15.62 & 16.21 \\
\hline C06 & C-D & 9.97 & 71.56 & 81.53 & 1.49 & 18.74 & 20.23 & 0.35 & 4.45 & 4.80 \\
\hline C07 & D-E & 16.50 & 124.40 & 140.90 & 2.46 & 32.57 & 35.03 & 0.59 & 7.74 & 8.33 \\
\hline C08 & D-E & 16.50 & 16.91 & 33.41 & 2.46 & 4.43 & 6.89 & 0.59 & 1.05 & 1.64 \\
\hline C10 & C-D & 9.97 & 473.88 & 483.85 & 1.49 & 124.08 & 125.57 & 0.35 & 29.50 & 29.85 \\
\hline C11 & C-D & 9.97 & 118.83 & 128.80 & 1.49 & 31.11 & 32.60 & 0.35 & 7.40 & 7.75 \\
\hline C12 & C-D & 9.97 & 171.98 & 181.95 & 1.49 & 45.03 & 46.52 & 0.35 & 10.70 & 11.05 \\
\hline C13 & D-E & 16.50 & 165.92 & 182.42 & 2.46 & 43.44 & 45.90 & 0.59 & 10.33 & 10.92 \\
\hline C14 & D-E & 16.50 & 130.89 & 147.39 & 2.46 & 34.26 & 36.72 & 0.59 & 8.15 & 8.74 \\
\hline C15 & D-E & 16.50 & 82.96 & 99.46 & 2.46 & 21.71 & 24.17 & 0.59 & 5.16 & 5.75 \\
\hline C16 & D-E & 16.50 & 6.11 & 22.61 & 2.46 & 1.60 & 4.06 & 0.59 & 0.38 & 0.97 \\
\hline E01 & A-B & 3.00 & 3.50 & 6.50 & 0.45 & 0.92 & 1.37 & 0.11 & 0.22 & 0.33 \\
\hline E02 & A-B & 3.00 & 0.56 & 3.56 & 0.45 & 0.15 & 0.60 & 0.11 & 0.04 & 0.15 \\
\hline E03 & B-C & 5.50 & 18.90 & 24.40 & 0.82 & 4.95 & 5.77 & 0.20 & 1.18 & 1.38 \\
\hline E04 & B-C & 5.50 & 13.77 & 19.27 & 0.82 & 3.60 & 4.42 & 0.20 & 0.86 & 1.06 \\
\hline
\end{tabular}


TABLE 5. Total EFFective Dose RATES For NEPTUNE AT CAU 551 SoIl SAMPLE Locations (CONTINUED)

\begin{tabular}{|c|c|c|c|c|c|c|c|c|c|c|}
\hline \multirow[b]{2}{*}{$\begin{array}{c}\text { CAU } 551 \\
\text { SAMPLE } \\
\text { LOCATION }\end{array}$} & \multirow{2}{*}{$\begin{array}{c}1994 \\
\text { FLYOVER } \\
\text { MAN-MADE } \\
\text { BIN* }\end{array}$} & \multicolumn{3}{|c|}{ INDUSTRIAL } & \multicolumn{3}{|c|}{ REMOTE WORK } & \multicolumn{3}{|c|}{ OCCASIONAL USE } \\
\hline & & $\begin{array}{c}\text { EXTERNAL } \\
\text { DOSE RATE } \\
\text { (mrem/yr) }\end{array}$ & $\begin{array}{c}\text { INTERNAL } \\
\text { DOSE RATE } \\
\text { (mrem/yr) }\end{array}$ & $\begin{array}{c}\text { TOTAL } \\
\text { EFFECTIVE } \\
\text { DoSE RATE } \\
\text { (mrem/yr) }\end{array}$ & $\begin{array}{c}\text { EXTERNAL } \\
\text { DOSE RATE } \\
\text { (mrem/yr) }\end{array}$ & $\begin{array}{c}\text { INTERNAL } \\
\text { DOSE RATE } \\
\text { (mrem/yr) }\end{array}$ & $\begin{array}{c}\text { TOTAL } \\
\text { EFFECTIVE } \\
\text { DOSE RATE } \\
\text { (mrem/yr) }\end{array}$ & $\begin{array}{c}\text { EXTERNAL } \\
\text { DOSE RATE } \\
\text { (mrem/yr) }\end{array}$ & $\begin{array}{c}\text { INTERNAL } \\
\text { DOSE RATE } \\
\text { (mrem/yr) }\end{array}$ & $\begin{array}{c}\text { TOTAL } \\
\text { EFFECTIVE } \\
\text { DoSE RATE } \\
\text { (mrem/yr) }\end{array}$ \\
\hline E06 & C-D & 9.97 & 28.98 & 38.95 & 1.49 & 7.59 & 9.08 & 0.35 & 1.80 & 2.15 \\
\hline E07 & C-D & 9.97 & 31.62 & 41.59 & 1.49 & 8.28 & 9.77 & 0.35 & 1.97 & 2.32 \\
\hline E08 & C-D & 9.97 & 0.11 & 10.08 & 1.49 & 0.03 & 1.52 & 0.35 & 0.01 & 0.36 \\
\hline E09 & C-D & 9.97 & 4.19 & 14.16 & 1.49 & 1.10 & 2.59 & 0.35 & 0.26 & 0.61 \\
\hline E10 & C-D & 9.97 & 29.77 & 39.74 & 1.49 & 7.80 & 9.29 & 0.35 & 1.85 & 2.20 \\
\hline E11 & B-C & 5.50 & 1.55 & 7.05 & 0.82 & 0.41 & 1.23 & 0.20 & 0.10 & 0.30 \\
\hline E12 & A-B & 3.00 & 0.08 & 3.08 & 0.45 & 0.02 & 0.47 & 0.11 & 0.01 & 0.12 \\
\hline E13 & N/A & 1.08 & 13.56 & 14.64 & 0.16 & 3.55 & 3.71 & 0.04 & 0.84 & 0.88 \\
\hline E14 & A-B & 3.00 & 20.04 & 23.04 & 0.45 & 5.25 & 5.70 & 0.11 & 1.25 & 1.36 \\
\hline E15 & A-B & 3.00 & 0.05 & 3.05 & 0.45 & 0.01 & 0.46 & 0.11 & 0.00 & 0.11 \\
\hline E18 & A-B & 3.00 & 0.03 & 3.03 & 0.45 & 0.01 & 0.46 & 0.11 & 0.00 & 0.11 \\
\hline E19 & A-B & 3.00 & 0.13 & 3.13 & 0.45 & 0.03 & 0.48 & 0.11 & 0.01 & 0.12 \\
\hline E20 & A-B & 3.00 & 0.03 & 3.03 & 0.45 & 0.01 & 0.46 & 0.11 & 0.00 & 0.11 \\
\hline E21 & N/A & 1.08 & 0.02 & 1.10 & 0.16 & 0.01 & 0.17 & 0.04 & 0.00 & 0.04 \\
\hline E22 & N/A & 1.08 & 0.05 & 1.13 & 0.16 & 0.01 & 0.17 & 0.04 & 0.00 & 0.04 \\
\hline E23 & N/A & 1.08 & 0.12 & 1.20 & 0.16 & 0.03 & 0.19 & 0.04 & 0.01 & 0.05 \\
\hline E24 & A-B & 3.00 & 0.03 & 3.03 & 0.45 & 0.01 & 0.46 & 0.11 & 0.00 & 0.11 \\
\hline E25 & A-B & 3.00 & 0.10 & 3.10 & 0.45 & 0.03 & 0.48 & 0.11 & 0.01 & 0.12 \\
\hline E26 & A-B & 3.00 & 0.39 & 3.39 & 0.45 & 0.10 & 0.55 & 0.11 & 0.02 & 0.13 \\
\hline
\end{tabular}


TABLE 5. TotAl EFFECTIVE Dose RATES FOR NEPTUNE AT CAU 551 SoIl SAMPLE LOCATIONS (CONTINUED)

\begin{tabular}{|c|c|c|c|c|c|c|c|c|c|c|}
\hline \multirow[b]{2}{*}{$\begin{array}{c}\text { CAU } 551 \\
\text { SAMPLE } \\
\text { LOCATION }\end{array}$} & \multirow{2}{*}{$\begin{array}{c}1994 \\
\text { FLYOVER } \\
\text { MAN-MADE } \\
\text { BIN* }\end{array}$} & \multicolumn{3}{|c|}{ INDUSTRIAL } & \multicolumn{3}{|c|}{ REMOTE WORK } & \multicolumn{3}{|c|}{ OCCASIONAL USE } \\
\hline & & $\begin{array}{c}\text { EXTERNAL } \\
\text { DOSE RATE } \\
\text { (mrem/yr) }\end{array}$ & $\begin{array}{c}\text { INTERNAL } \\
\text { DOSE RATE } \\
\text { (mrem/yr) }\end{array}$ & $\begin{array}{c}\text { TOTAL } \\
\text { EFFECTIVE } \\
\text { DOSE RATE } \\
\text { (mrem/yr) }\end{array}$ & $\begin{array}{c}\text { EXTERNAL } \\
\text { DOSE RATE } \\
\text { (mrem/yr) }\end{array}$ & $\begin{array}{c}\text { INTERNAL } \\
\text { DOSE RATE } \\
\text { (mrem/yr) }\end{array}$ & $\begin{array}{c}\text { TOTAL } \\
\text { EFFECTIVE } \\
\text { DOSE RATE } \\
\text { (mrem/yr) }\end{array}$ & $\begin{array}{c}\text { EXTERNAL } \\
\text { DOSE RATE } \\
\text { (mrem/yr) }\end{array}$ & $\begin{array}{c}\text { INTERNAL } \\
\text { DOSE RATE } \\
\text { (mrem/yr) }\end{array}$ & $\begin{array}{c}\text { TOTAL } \\
\text { EFFECTIVE } \\
\text { DOSE RATE } \\
\text { (mrem/yr) }\end{array}$ \\
\hline E27 & A-B & 3.00 & 0.25 & 3.25 & 0.45 & 0.06 & 0.51 & 0.11 & 0.02 & 0.13 \\
\hline E28 & N/A & 1.08 & 0.10 & 1.18 & 0.16 & 0.03 & 0.19 & 0.04 & 0.01 & 0.05 \\
\hline E29 & B-C & 5.50 & 0.15 & 5.65 & 0.82 & 0.04 & 0.86 & 0.20 & 0.01 & 0.21 \\
\hline E30 & C-D & 9.97 & 15.07 & 25.04 & 1.49 & 3.94 & 5.43 & 0.35 & 0.94 & 1.29 \\
\hline E31 & C-D & 9.97 & 137.04 & 147.01 & 1.49 & 35.87 & 37.36 & 0.35 & 8.53 & 8.88 \\
\hline E32 & C-D & 9.97 & 103.04 & 113.01 & 1.49 & 26.98 & 28.47 & 0.35 & 6.41 & 6.76 \\
\hline E33 & C-D & 9.97 & 19.31 & 29.28 & 1.49 & 5.06 & 6.55 & 0.35 & 1.20 & 1.55 \\
\hline E34 & C-D & 9.97 & 130.52 & 140.49 & 1.49 & 34.16 & 35.65 & 0.35 & 8.12 & 8.47 \\
\hline E35 & D-E & 16.50 & 24.64 & 41.14 & 2.46 & 6.45 & 8.91 & 0.59 & 1.53 & 2.12 \\
\hline E36 & C-D & 9.97 & 3.12 & 13.09 & 1.49 & 0.82 & 2.31 & 0.35 & 0.19 & 0.54 \\
\hline E37 & A-B & 3.00 & 0.04 & 3.04 & 0.45 & 0.01 & 0.46 & 0.11 & 0.00 & 0.11 \\
\hline E38 & N/A & 1.08 & 0.39 & 1.47 & 0.16 & 0.10 & 0.26 & 0.04 & 0.02 & 0.06 \\
\hline E39 & N/A & 1.08 & 0.12 & 1.20 & 0.16 & 0.03 & 0.19 & 0.04 & 0.01 & 0.05 \\
\hline E40 & N/A & 1.08 & 0.01 & 1.09 & 0.16 & 0.00 & 0.16 & 0.04 & 0.00 & 0.04 \\
\hline E41 & A-B & 3.00 & 0.12 & 3.12 & 0.45 & 0.03 & 0.48 & 0.11 & 0.01 & 0.12 \\
\hline E42 & A-B & 3.00 & 0.33 & 3.33 & 0.45 & 0.09 & 0.54 & 0.11 & 0.02 & 0.13 \\
\hline
\end{tabular}

mrem/yr = millirem(s) per year

* The 1994 flyover man-made bins are identified in Figure 5.

NOTE: Results greater than the final action level of 25 millirems per year are identified by bold text.

NOTE: Samples collected outside the existing use restriction for Corrective Action Unit 551 are shaded gray. 
TABle 6. Total EfFective Dose RATES For NEPTUNE USING CORRElATEd 1994 Flyover DATA,

BASED ON THE INDUSTRIAL AREA EXPOSURE SCENARIO

\begin{tabular}{|c|c|c|c|c|c|c|c|}
\hline & & $\begin{array}{c}1994 \text { FLYOVER } \\
\text { MAN-MADE BIN* }\end{array}$ & N/A & A-B & B-C & C-D & D-E \\
\hline & & $\begin{array}{l}\text { 95\% UCL EXTERNAL } \\
\text { DOSE RATE (mrem/yr) }\end{array}$ & 1.08 & 3 & 5.5 & 9.97 & 16.5 \\
\hline $\begin{array}{l}1994 \text { FLYOVER } \\
\text { AMERICIUM BIN* }\end{array}$ & $\begin{array}{l}\text { 95\% UCL INTERNAL } \\
\text { DOSE RATE (mrem/yr) }\end{array}$ & & \multicolumn{5}{|c|}{$\begin{array}{c}\text { INDUSTRIAL AREA } \\
\text { TOTAL EFFECTIVE DOSE RATE (mrem/yr) }\end{array}$} \\
\hline N/A & 1.35 & & 2.43 & 4.35 & 6.85 & 11.32 & 17.85 \\
\hline Am Bin A-B & 4.68 & & 5.76 & 7.68 & 10.18 & 14.65 & 21.18 \\
\hline Am Bin B-C & 6.52 & & 7.60 & 9.52 & 12.02 & 16.49 & 23.02 \\
\hline Am Bin C-D & 46.07 & & 47.15 & 49.07 & 51.57 & 56.04 & 62.57 \\
\hline
\end{tabular}

mrem/yr = millirem(s) per year

UCL = upper confidence limit

* The 1994 flyover bins are identified in Figure 5.

NOTE: Results greater than the final action level of 25 millirems per year are identified by bold text.

TABle 7. Total EFFECTIVE Dose RATES FOR NEPTUNE USING CORRELATEd 1994 Flyover DATA, BASED ON THE REMOTE WORK AREA EXPOSURE SCENARIO

\begin{tabular}{|c|c|c|c|c|c|c|c|}
\hline & & $\begin{array}{c}1994 \text { FLYOVER } \\
\text { MAN-MADE BIN* }\end{array}$ & N/A & A-B & B-C & C-D & D-E \\
\hline & & $\begin{array}{l}\text { 95\% UCL EXTERNAL } \\
\text { DOSE RATE (mrem/yr) }\end{array}$ & 0.16 & 0.45 & 0.82 & 1.49 & 2.46 \\
\hline $\begin{array}{c}1994 \text { FLYOVER } \\
\text { AMERICIUM BIN* } \\
\end{array}$ & $\begin{array}{l}\text { 95\% UCL INTERNAL } \\
\text { DOSE RATE (mrem/yr) }\end{array}$ & & & $\begin{array}{r}R \\
\text { AL EFF } \\
\end{array}$ & $\begin{array}{l}\text { E Wor } \\
\text { E Dos }\end{array}$ & E (mre & \\
\hline N/A & 0.35 & & 0.51 & 0.80 & 1.17 & 1.84 & 2.81 \\
\hline Am Bin A-B & 1.23 & & 1.39 & 1.68 & 2.05 & 2.72 & 3.69 \\
\hline Am Bin B-C & 1.71 & & 1.87 & 2.16 & 2.53 & 3.20 & 4.17 \\
\hline Am Bin C-D & 12.07 & & 12.23 & 12.52 & 12.89 & 13.56 & 14.53 \\
\hline
\end{tabular}

mrem/yr = millirem(s) per year

UCL = upper confidence limit

* The 1994 flyover bins are identified in Figure 5. 
TABle 8. Total EFFective Dose RATES For NEPTUNE USING CORRElATEd 1994 Flyover DATA,

\section{BASED ON THE OCCASIONAL USE AREA EXPOSURE SCENARIO}

\begin{tabular}{|c|c|c|c|c|c|c|c|}
\hline & & $\begin{array}{c}1994 \text { FLYOVER } \\
\text { MAN-MADE BIN* }\end{array}$ & N/A & A-B & B-C & C-D & D-E \\
\hline & & $\begin{array}{l}\text { 95\% UCL EXTERNAL } \\
\text { DOSE RATE (mrem/yr) }\end{array}$ & 0.04 & 0.11 & 0.2 & 0.35 & 0.59 \\
\hline $\begin{array}{l}1994 \text { FLYOVER } \\
\text { AMERICIUM BIN* }\end{array}$ & $\begin{array}{l}\text { 95\% UCL INTERNAL } \\
\text { DOSE RATE (mrem/yr) }\end{array}$ & & & $\begin{array}{r}\text { O } \\
L \text { EFF }\end{array}$ & $\begin{array}{l}\text { NAL I } \\
\text { DOS }\end{array}$ & $\begin{array}{l}\text { EA } \\
(\text { mre }\end{array}$ & \\
\hline N/A & 0.08 & & 0.12 & 0.19 & 0.28 & 0.43 & 0.67 \\
\hline Am Bin A-B & 0.29 & & 0.33 & 0.40 & 0.49 & 0.64 & 0.88 \\
\hline Am Bin B-C & 0.41 & & 0.45 & 0.52 & 0.61 & 0.76 & 1.00 \\
\hline Am Bin C-D & 2.87 & & 2.91 & 2.98 & 3.07 & 3.22 & 3.46 \\
\hline
\end{tabular}

mrem/yr = millirem(s) per year

UCL = upper confidence limit

* The 1994 flyover bins are identified in Figure 5. 


\subsubsection{Corrective Action Site 12-45-01, U12e.05 Crater (Blanca)}

BLANCA is located on the very steep east-facing slope of the eastern side of Rainier Mesa in Area 12 of the NNSS. The general slope of the site is between 30 and 45 degrees; however, the site is steeper near the top of the mesa. Since BLANCA had a fission yield, the primary contaminants present are fission products, which include high-level gamma emissions that lead to external dose. Therefore, the external dose component of TED was expected to be the decision driver at this site (NNSA/NSO, 2011).

Access to BLANCA is limited due to its remote location and very steep and rocky terrain. Photographs of the site are provided in Figures 6 and 7. There is no anticipated future use of this area, and the steep slope and rough terrain surrounding the site essentially precludes access and use.

For BLANCA, additional data were collected to delineate the extent of contamination that exceeds the FAL to define a UR. Existing characterization data were also used to validate assumptions.

\subsubsection{External Dose Rates}

External dose rates at BLANCA were first projected using correlated 1994 flyover data, as described in Radionuclide Inventory Distribution Project Data Evaluation and Verification White Paper (NSTec, 2008). The 1994 flyover results are shown in Figure 8, and the man-made exposure rate isopleths are labeled Isopleth A through E. Table 9 provides the 95-percent UCL of the average external dose for each man-made exposure rate bin and for each exposure scenario.

External dose rates at BLANCA were then verified with in situ measurements using TLDs. A total of 19 TLDs, including 2 blind duplicates, were placed at the locations shown in Figure 8. The TLDs were placed at a height of approximately 1 meter above the ground surface and exposed for more than 2,250 hours, the time used for the Industrial Area exposure scenario. Due to the extremely steep and rocky terrain of the site, the area of highest contamination detected by the 1994 flyover (the area within man-made exposure rate Isopleth E) could not be safely accessed to place TLDs.

Measurements for background radiation, which is radioactivity that cannot be attributed to a specific source but is due to low-level, worldwide natural and man-made sources, were continuously collected during the 1994 flyover. NNSS-wide environmental TLD data were correlated to the background measurements obtained by the 1994 flyover. The lowest background measurement calculated for the site was conservatively subtracted from the total TLD reading at all TLD locations. The net external dose (total TLD reading minus background dose) was divided by the number of hours the TLD was exposed to site contamination, resulting in an hourly dose rate. The hourly dose rate was then multiplied by the number of hours per year a site worker would be present under each exposure scenario to establish the maximum potential annual external dose a site worker could receive for each exposure scenario.

Table 10 lists the total TLD readings, the background dose at each TLD location, and the net external dose for each exposure scenario. 


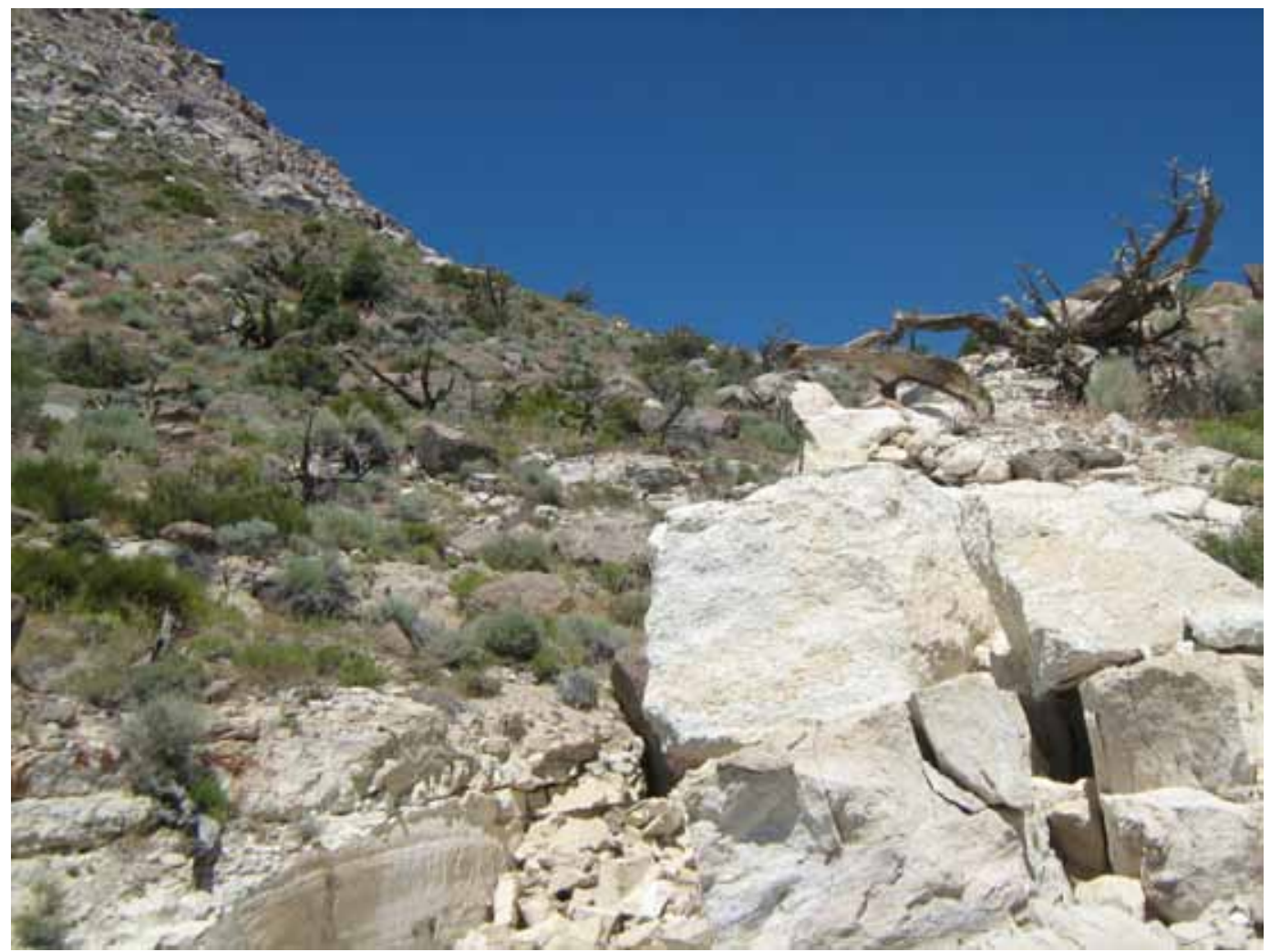

FIGURE 6. TLD LOCATION 16, 07/19/2011

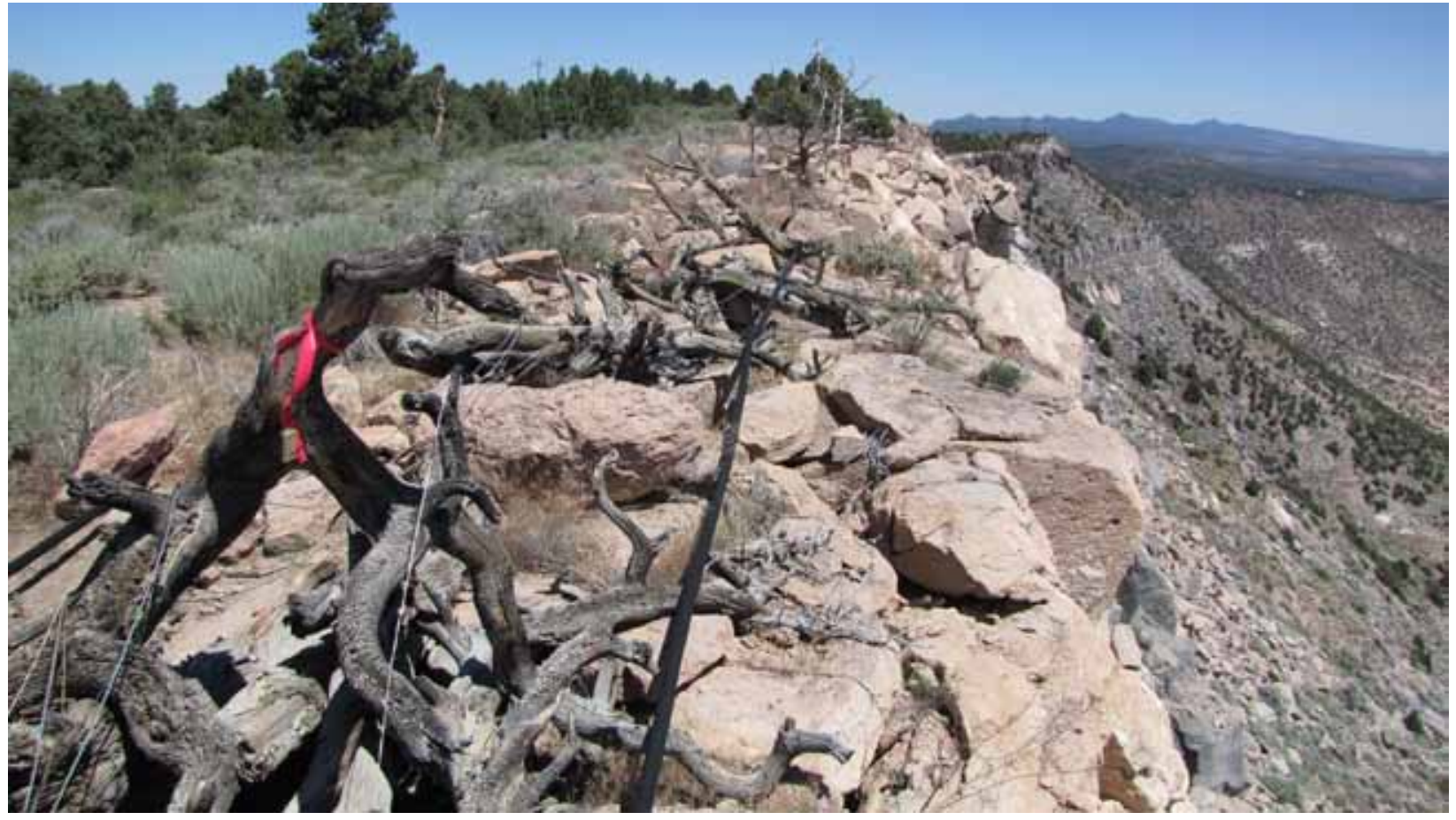

FIGURE 7. TLD LOCATION 2, 07/21/2011 
Revision: 0

Date: April 2012

THIS PAGE INTENTIONALLY LEFT BLANK 


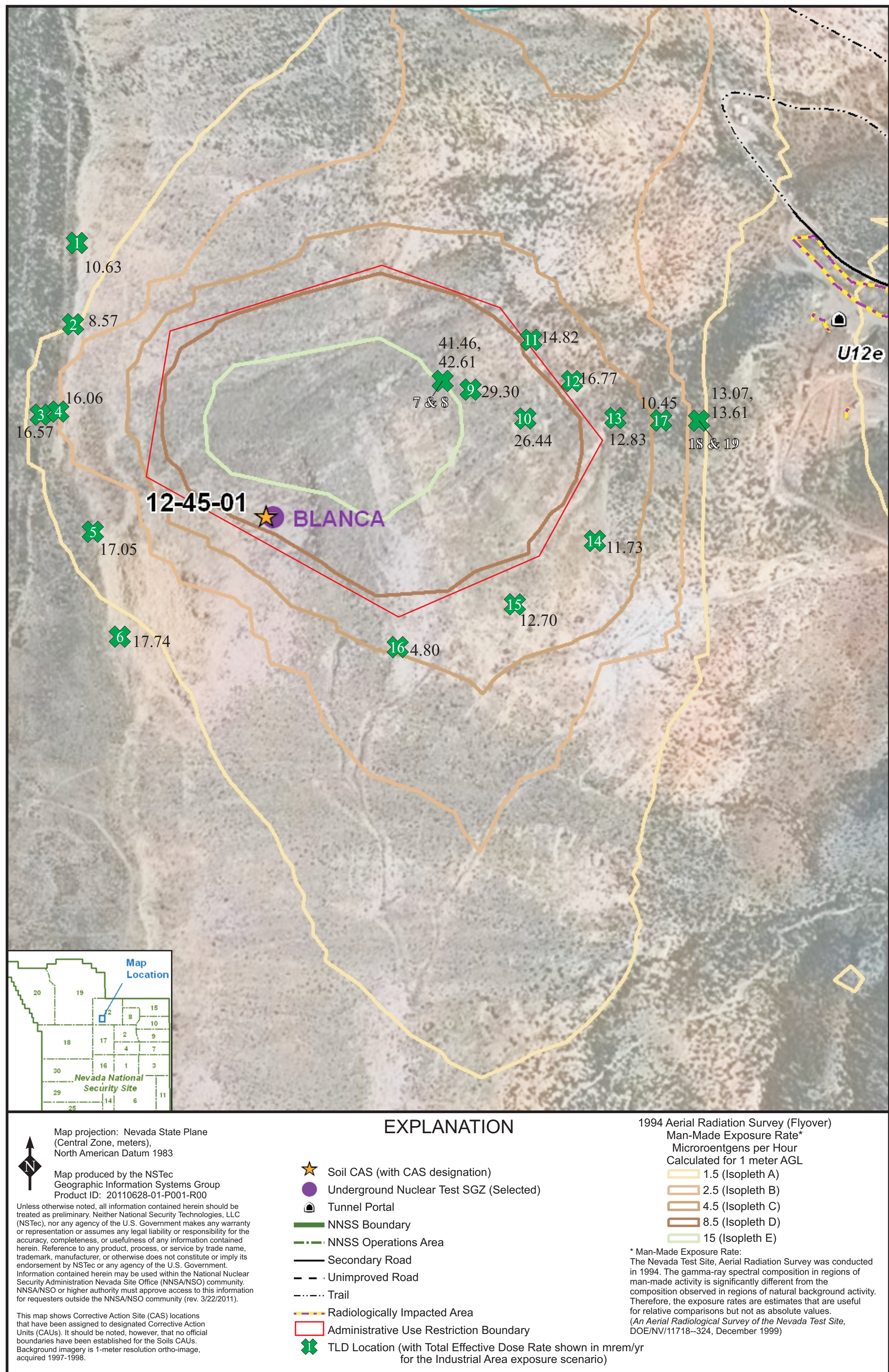

FigURE 8

BLANCA Total EFFective Dose Rates AND ADMINISTRATIVE USE RESTRICTION BOUNDARY 
CAU 574 Closure Report

Section: Closure Activities

Date: April 2012

THIS PAGE INTENTIONALLY LEFT BLANK 
TABLE 9. External Dose RATES For BLANCA Using CORRELATED 1994 Flyover DATA

\begin{tabular}{|c|c|c|c|c|c|c|c|c|}
\hline \multirow{2}{*}{$\begin{array}{c}1994 \\
\text { FLYOVER } \\
\text { MAN-MADE } \\
\text { BIN* }\end{array}$} & \multirow{2}{*}{$\begin{array}{c}1994 \\
\text { FLYOVER } \\
\text { MAN-MADE } \\
\text { EXPOSURE } \\
\text { RATE }(\boldsymbol{\mu R} / \mathbf{h r})\end{array}$} & \multirow{2}{*}{$\begin{array}{c}\text { NUMBER OF } \\
\text { RIDP } \\
\text { MEASUREMENTS } \\
\text { COLLECTED }\end{array}$} & \multicolumn{2}{|c|}{ INDUSTRIAL } & \multicolumn{2}{|c|}{ REMOTE WORK } & \multicolumn{2}{|c|}{ OCCASIONAL USE } \\
\hline & & & $\begin{array}{c}\text { AVERAGE } \\
\text { EXTERNAL } \\
\text { DOSE RATE } \\
\text { (mrem/yr) }\end{array}$ & $\begin{array}{c}95 \% \text { UCL } \\
\text { EXTERNAL } \\
\text { DOSE RATE } \\
\text { (mrem/yr) }\end{array}$ & $\begin{array}{c}\text { AVERAGE } \\
\text { EXTERNAL } \\
\text { DOSE RATE } \\
(\mathrm{mrem} / \mathrm{yr})\end{array}$ & $\begin{array}{c}\text { 95\% UCL } \\
\text { EXTERNAL } \\
\text { DOSE RATE } \\
(\mathrm{mrem} / \mathrm{yr})\end{array}$ & $\begin{array}{c}\text { AVERAGE } \\
\text { EXTERNAL } \\
\text { DOSE RATE } \\
\text { (mrem/yr) }\end{array}$ & $\begin{array}{c}\text { 95\% UCL } \\
\text { EXTERNAL } \\
\text { DOSE RATE } \\
\text { (mrem/yr) }\end{array}$ \\
\hline N/A & $0-1.5$ & 2,075 & 1.03 & 1.08 & 0.15 & 0.16 & 0.04 & 0.04 \\
\hline A-B & $1.5-2.5$ & 386 & 2.67 & 3.00 & 0.40 & 0.45 & 0.09 & 0.11 \\
\hline B-C & $2.5-4.5$ & 302 & 4.44 & 5.50 & 0.66 & 0.82 & 0.16 & 0.20 \\
\hline C-D & $4.5-8.5$ & 279 & 8.16 & 9.97 & 1.22 & 1.49 & 0.29 & 0.35 \\
\hline $\mathrm{D}-\mathrm{E}$ & $8.5-15$ & 251 & 14.50 & 16.50 & 2.17 & 2.46 & 0.52 & 0.59 \\
\hline $\mathrm{E}-\mathrm{F}$ & $15-25$ & 164 & 22.60 & 25.40 & 3.37 & 3.79 & 0.80 & 0.90 \\
\hline
\end{tabular}

$\mu \mathrm{R} / \mathrm{hr}=$ microroentgen $(\mathrm{s})$ per hour

$\mathrm{mrem} / \mathrm{yr}=$ millirem(s) per year

UCL = upper confidence limit

* The 1994 flyover man-made bins are identified in Figure 8.

TABLe 10. ThermoluminesCent DOSIMETER EXTERnAl DOSE RATE RESUlTS FOR BLANCA

\begin{tabular}{|c|c|c|c|c|c|c|c|c|c|c|}
\hline \multirow[b]{2}{*}{$\begin{array}{c}\text { TLD } \\
\text { LOCATION }\end{array}$} & \multirow[b]{2}{*}{$\begin{array}{c}1994 \\
\text { FLYOVER } \\
\text { MAN-MADE } \\
\text { BIN* }\end{array}$} & \multicolumn{3}{|c|}{ INDUSTRIAL } & \multicolumn{3}{|c|}{ REMOTE WORK } & \multicolumn{3}{|c|}{ OCCASIONAL USE } \\
\hline & & $\begin{array}{c}\text { TOTAL } \\
\text { EXTERNAL } \\
\text { DOSE RATE } \\
\text { (mrem/yr) }\end{array}$ & $\begin{array}{c}\text { BACK- } \\
\text { GROUND } \\
\text { EXTERNAL } \\
\text { DOSE RATE } \\
\text { (mrem/yr) }\end{array}$ & $\begin{array}{c}\text { NET } \\
\text { EXTERNAL } \\
\text { DOSE RATE } \\
\text { (mrem/yr) }\end{array}$ & $\begin{array}{c}\text { TOTAL } \\
\text { EXTERNAL } \\
\text { DOSE RATE } \\
\text { (mrem/yr) }\end{array}$ & $\begin{array}{c}\text { BACK- } \\
\text { GROUND } \\
\text { EXTERNAL } \\
\text { DOSE RATE } \\
\text { (mrem/yr) }\end{array}$ & $\begin{array}{c}\text { NET } \\
\text { EXTERNAL } \\
\text { DOSE RATE } \\
\text { (mrem/yr) }\end{array}$ & $\begin{array}{c}\text { TOTAL } \\
\text { EXTERNAL } \\
\text { DOSE RATE } \\
(\mathrm{mrem} / \mathrm{yr})\end{array}$ & $\begin{array}{c}\text { BACK- } \\
\text { GROUND } \\
\text { EXTERNAL } \\
\text { DOSE RATE } \\
\text { (mrem/yr) }\end{array}$ & $\begin{array}{c}\text { NET } \\
\text { EXTERNAL } \\
\text { DOSE RATE } \\
\text { (mrem/yr) }\end{array}$ \\
\hline 1 & N/A & 41.31 & 31.36 & 9.95 & 6.17 & 4.68 & 1.49 & 1.47 & 1.12 & 0.35 \\
\hline 2 & A-B & 39.25 & 31.36 & 7.89 & 5.86 & 4.68 & 1.18 & 1.40 & 1.12 & 0.28 \\
\hline 3 & A-B & 47.25 & 31.36 & 15.89 & 7.06 & 4.68 & 2.38 & 1.68 & 1.12 & 0.56 \\
\hline 4 & A-B & 46.74 & 31.36 & 15.38 & 6.98 & 4.68 & 2.30 & 1.66 & 1.12 & 0.54 \\
\hline
\end{tabular}


TABLE 10. THERMOLUMinESCENT DOSIMETER EXTERNAL DOSE RATE RESULTS FOR BLANCA (CONTINUED)

\begin{tabular}{|c|c|c|c|c|c|c|c|c|c|c|}
\hline \multirow[b]{2}{*}{$\begin{array}{c}\text { TLD } \\
\text { LOCATION }\end{array}$} & \multirow[b]{2}{*}{$\begin{array}{c}1994 \\
\text { FLYOVER } \\
\text { MAN-MADE } \\
\text { BIN* }\end{array}$} & \multicolumn{3}{|c|}{ INDUSTRIAL } & \multicolumn{3}{|c|}{ REMOTE WORK } & \multicolumn{3}{|c|}{ OCCASIONAL USE } \\
\hline & & $\begin{array}{c}\text { TOTAL } \\
\text { EXTERNAL } \\
\text { DOSE RATE } \\
\text { (mrem/yr) }\end{array}$ & $\begin{array}{c}\text { BACK- } \\
\text { GROUND } \\
\text { EXTERNAL } \\
\text { DOSE RATE } \\
\text { (mrem/yr) }\end{array}$ & $\begin{array}{c}\text { NET } \\
\text { EXTERNAL } \\
\text { DOSE RATE } \\
\text { (mrem/yr) }\end{array}$ & $\begin{array}{c}\text { TOTAL } \\
\text { EXTERNAL } \\
\text { DOSE RATE } \\
\text { (mrem/yr) }\end{array}$ & $\begin{array}{c}\text { BACK- } \\
\text { GROUND } \\
\text { EXTERNAL } \\
\text { DOSE RATE } \\
\text { (mrem/yr) }\end{array}$ & $\begin{array}{c}\text { NET } \\
\text { EXTERNAL } \\
\text { DOSE RATE } \\
\text { (mrem/yr) }\end{array}$ & $\begin{array}{c}\text { TOTAL } \\
\text { EXTERNAL } \\
\text { DOSE RATE } \\
\text { (mrem/yr) }\end{array}$ & $\begin{array}{c}\text { BACK- } \\
\text { GROUND } \\
\text { EXTERNAL } \\
\text { DOSE RATE } \\
\text { (mrem/yr) }\end{array}$ & $\begin{array}{c}\text { NET } \\
\text { EXTERNAL } \\
\text { DOSE RATE } \\
\text { (mrem/yr) }\end{array}$ \\
\hline 5 & A-B & 47.73 & 31.36 & 16.37 & 7.13 & 4.68 & 2.45 & 1.70 & 1.12 & 0.58 \\
\hline 6 & N/A & 48.42 & 31.36 & 17.06 & 7.23 & 4.68 & 2.55 & 1.72 & 1.12 & 0.60 \\
\hline 7 & D-E & 72.14 & 31.36 & 40.78 & 10.77 & 4.68 & 6.09 & 2.57 & 1.12 & 1.45 \\
\hline 8 & $\mathrm{D}-\mathrm{E}$ & 73.29 & 31.36 & 41.93 & 10.94 & 4.68 & 6.26 & 2.61 & 1.12 & 1.49 \\
\hline 9 & $\mathrm{D}-\mathrm{E}$ & 59.98 & 31.36 & 28.62 & 8.96 & 4.68 & 4.28 & 2.13 & 1.12 & 1.01 \\
\hline 10 & $\mathrm{D}-\mathrm{E}$ & 57.12 & 31.36 & 25.76 & 8.53 & 4.68 & 3.85 & 2.03 & 1.12 & 0.91 \\
\hline 11 & C-D & 45.50 & 31.36 & 14.14 & 6.79 & 4.68 & 2.11 & 1.62 & 1.12 & 0.50 \\
\hline 12 & C-D & 47.45 & 31.36 & 16.09 & 7.09 & 4.68 & 2.41 & 1.69 & 1.12 & 0.57 \\
\hline 13 & C-D & 43.51 & 31.36 & 12.15 & 6.50 & 4.68 & 1.82 & 1.55 & 1.12 & 0.43 \\
\hline 14 & C-D & 42.41 & 31.36 & 11.05 & 6.33 & 4.68 & 1.65 & 1.51 & 1.12 & 0.39 \\
\hline 15 & C-D & 43.38 & 31.36 & 12.02 & 6.48 & 4.68 & 1.80 & 1.54 & 1.12 & 0.42 \\
\hline 16 & C-D & 35.48 & 31.36 & 4.12 & 5.30 & 4.68 & 0.62 & 1.26 & 1.12 & 0.14 \\
\hline 17 & B-C & 41.13 & 31.36 & 9.77 & 6.14 & 4.68 & 1.46 & 1.46 & 1.12 & 0.34 \\
\hline 18 & A-B & 43.75 & 31.36 & 12.39 & 6.53 & 4.68 & 1.85 & 1.56 & 1.12 & 0.44 \\
\hline 19 & A-B & 44.29 & 31.36 & 12.93 & 6.61 & 4.68 & 1.93 & 1.57 & 1.12 & 0.45 \\
\hline
\end{tabular}

$\mathrm{mrem} / \mathrm{yr}=$ millirem(s) per year

* The 1994 flyover man-made bins are identified in Figure 8. 


\subsubsection{Internal Dose Rates}

Am-241 was not detected at BLANCA by the 1994 flyover; therefore, it was assumed that internal dose does not significantly contribute to TED at this site. Collection of soil samples to quantify this small component of TED was not required. The highest RIDP values across the NNSS for non-Am gamma emitters and inferred strontium-90 from areas with the same level of contamination as that detected at BLANCA by the 1994 flyover were conservatively used to calculate internal dose for each exposure scenario. The method used to convert RIDP data is described in Radionuclide Inventory Distribution Project Data Evaluation and Verification White Paper (NSTec, 2008), which is included as Appendix C of this document. As shown in Table 11, this approach confirmed that internal dose at the site is negligible.

\subsubsection{Total Effective Dose Rates and Use Restriction Boundary Determination}

TED for BLANCA was determined by summing the internal and external dose components. The internal dose rates in Table 11 were applied at all TLD locations. The TED at each TLD location is listed in Table 12 for each exposure scenario. Results greater than the FAL of 25 mrem/yr are identified by bold text. Four TLD measurements exceed the 25-mrem/yr FAL for the Industrial Area exposure scenario. Based on TLD data, the boundary of the 25-mrem/yr Industrial Area is Isopleth $\mathrm{D}(8.5 \mu \mathrm{R} / \mathrm{hr})$. The TED rates at all TLD locations outside Isopleth $\mathrm{D}$ are less than $25 \mathrm{mrem} / \mathrm{yr}$ for the Industrial Area exposure scenario. Industrial Area TED rates are shown in Figure 8. None of the TLD measurements exceed the 25-mrem/yr FAL for the Remote Work Area or Occasional Use Area exposure scenarios.

To determine TED for BLANCA in areas that could not be safely accessed to place TLDs, the external dose rates projected using correlated 1994 flyover data (Table 9) and the internal dose rates listed in Table 11 were summed. Table 13 lists the projected TED rates for each exposure scenario. The 25-mrem/yr FAL is exceeded for the Industrial Area exposure scenario based on these data. The projected boundary of the $25-\mathrm{mrem} / \mathrm{yr}$ Industrial Area is Isopleth $\mathrm{D}(8.5 \mu \mathrm{R} / \mathrm{hr})$. Because the calculated TED is approximately $26 \mathrm{mrem} / \mathrm{yr}$ on Isopleth $\mathrm{E}$, the 25-mrem/yr boundary is conservatively chosen at the next isopleth, Isopleth $\mathrm{D}$. As shown in Table 13, the 25-mrem/yr FAL is not exceeded for the Remote Work Area or Occasional Use Area exposure scenarios.

None of the TLD measurements exceed the 25-mrem/yr FAL for the Remote Work Area or Occasional Use Area exposure scenarios. The 1994 flyover data demonstrate that the 25-mrem/yr FAL is not exceeded for the Remote Work Area or Occasional Use Area exposure scenarios in the areas that could not be safely accessed to place TLDs. The 1994 flyover data project a TED of $3.89 \mathrm{mrem} / \mathrm{yr}$ based on the Remote Work exposure scenario and $0.93 \mathrm{mrem} / \mathrm{yr}$ based on the Occasional Use Area exposure scenario in the area within Isopleth E. Therefore, a UR is not required. However, because the 25-mrem/yr FAL is exceeded for the Industrial Area exposure scenario, an administrative UR was established as a BMP.

The administrative UR encompasses the 1994 flyover isopleth with a man-made exposure rate of $8.5 \mu \mathrm{R} / \mathrm{hr}$ (Isopleth D). The administrative UR restricts future activities that would result in a site worker exceeding the exposure time assumed under the current land usage. The administrative UR is recorded and controlled in the same manner as a FFACO UR but does not require postings or inspections. Any proposed activity within this area that would change the current exposure scenario based on a more intensive use of the site would require NDEP approval. 
TABLE 11. INTERNAL DOSE RATES FOR BLANCA USING RIDP DATA

Date: April 2012

\begin{tabular}{|c|c|c|c|c|c|c|c|}
\hline \multirow{2}{*}{ ISOTOPE } & \multirow{2}{*}{$\begin{array}{c}\text { MAXIMUM RIDP } \\
\text { CONCENTRATION } \\
\text { (pCi/g) }\end{array}$} & \multicolumn{3}{|c|}{$\begin{array}{l}\text { RESIDUAL RADIOACTIVE MATERIAL } \\
\text { GUIDELINE (pCi/g) }\end{array}$} & \multicolumn{3}{|c|}{ MAXIMUM INTERNAL DOSE RATE (mrem/yr) } \\
\hline & & INDUSTRIAL & $\begin{array}{l}\text { REMOTE } \\
\text { WORK }\end{array}$ & $\begin{array}{l}\text { OCCASIONAL } \\
\text { USE }\end{array}$ & INDUSTRIAL & $\begin{array}{l}\text { REMOTE } \\
\text { WORK }\end{array}$ & $\begin{array}{l}\text { OCCASIONAL } \\
\text { USE }\end{array}$ \\
\hline cobalt-60 & 34.67 & 105,800 & 652,500 & $2,744,000$ & 0.01 & 0.00 & 0.00 \\
\hline cesium-137 & 494.14 & 58,490 & 401,100 & $1,687,000$ & 0.21 & 0.03 & 0.01 \\
\hline europium-152 & 134.01 & 332,700 & $1,638,000$ & $6,891,000$ & 0.01 & 0.00 & 0.00 \\
\hline europium-154 & 75.59 & 236,800 & $1,198,000$ & $5,037,000$ & 0.01 & 0.00 & 0.00 \\
\hline europium-155 & 3.08 & $1,561,000$ & $8,055,000$ & $33,880,000$ & 0.00 & 0.00 & 0.00 \\
\hline strontium-90 & 312.53 & 17,770 & 109,000 & 458,600 & 0.44 & 0.07 & 0.02 \\
\hline \multicolumn{5}{|r|}{ Total } & 0.68 & 0.10 & 0.03 \\
\hline
\end{tabular}

pCi/g = picocurie(s) per gram

mrem/yr = millirem(s) per year 
TABLE 12. Total EFFECTIVE Dose RATES AT THERMOLUMINESCENT DOSIMETER LOCATIONS FOR BLANCA

\begin{tabular}{|c|c|c|c|c|c|c|c|c|c|c|}
\hline \multirow[b]{2}{*}{$\begin{array}{c}\text { TLD } \\
\text { LOCATION }\end{array}$} & \multirow[b]{2}{*}{$\begin{array}{c}1994 \\
\text { FLYOVER } \\
\text { MAN-MADE } \\
\text { BIN* }\end{array}$} & \multicolumn{3}{|c|}{ INDUSTRIAL } & \multicolumn{3}{|c|}{ REMOTE WORK } & \multicolumn{3}{|c|}{ OCCASIONAL USE } \\
\hline & & $\begin{array}{c}\text { MEASURED } \\
\text { EXTERNAL } \\
\text { DOSE RATE } \\
\text { (mrem/yr) }\end{array}$ & $\begin{array}{c}\text { MAXIMUM } \\
\text { INTERNAL } \\
\text { DOSE RATE } \\
\text { (mrem/yr) }\end{array}$ & $\begin{array}{c}\text { TOTAL } \\
\text { EFFECTIVE } \\
\text { DoSE RATE } \\
\text { (mrem/yr) }\end{array}$ & $\begin{array}{c}\text { MEASURED } \\
\text { EXTERNAL } \\
\text { DOSE RATE } \\
\text { (mrem/yr) }\end{array}$ & $\begin{array}{c}\text { MAXIMUM } \\
\text { INTERNAL } \\
\text { DOSE RATE } \\
\text { (mrem/yr) }\end{array}$ & $\begin{array}{c}\text { TOTAL } \\
\text { EFFECTIVE } \\
\text { DoSE RATE } \\
\text { (mrem/yr) }\end{array}$ & $\begin{array}{c}\text { MEASURED } \\
\text { EXTERNAL } \\
\text { DOSE RATE } \\
\text { (mrem/yr) }\end{array}$ & $\begin{array}{c}\text { MAXIMUM } \\
\text { INTERNAL } \\
\text { DOSE RATE } \\
\text { (mrem/yr) }\end{array}$ & $\begin{array}{c}\text { TOTAL } \\
\text { EFFECTIVE } \\
\text { DOSE RATE } \\
\text { (mrem/yr) }\end{array}$ \\
\hline 1 & N/A & 9.95 & 0.68 & 10.63 & 1.49 & 0.10 & 1.59 & 0.35 & 0.03 & 0.38 \\
\hline 2 & A-B & 7.89 & 0.68 & 8.57 & 1.18 & 0.10 & 1.28 & 0.28 & 0.03 & 0.31 \\
\hline 3 & A-B & 15.89 & 0.68 & 16.57 & 2.38 & 0.10 & 2.48 & 0.56 & 0.03 & 0.59 \\
\hline 4 & A-B & 15.38 & 0.68 & 16.06 & 2.30 & 0.10 & 2.40 & 0.54 & 0.03 & 0.57 \\
\hline 5 & A-B & 16.37 & 0.68 & 17.05 & 2.45 & 0.10 & 2.55 & 0.58 & 0.03 & 0.61 \\
\hline 6 & N/A & 17.06 & 0.68 & 17.74 & 2.55 & 0.10 & 2.65 & 0.60 & 0.03 & 0.63 \\
\hline 7 & $\mathrm{D}-\mathrm{E}$ & 40.78 & 0.68 & 41.46 & 6.09 & 0.10 & 6.19 & 1.45 & 0.03 & 1.48 \\
\hline 8 & D-E & 41.93 & 0.68 & 42.61 & 6.26 & 0.10 & 6.36 & 1.49 & 0.03 & 1.52 \\
\hline 9 & D-E & 28.62 & 0.68 & 29.30 & 4.28 & 0.10 & 4.38 & 1.01 & 0.03 & 1.04 \\
\hline 10 & D-E & 25.76 & 0.68 & 26.44 & 3.85 & 0.10 & 3.95 & 0.91 & 0.03 & 0.94 \\
\hline 11 & C-D & 14.14 & 0.68 & 14.82 & 2.11 & 0.10 & 2.21 & 0.50 & 0.03 & 0.53 \\
\hline 12 & C-D & 16.09 & 0.68 & 16.77 & 2.41 & 0.10 & 2.51 & 0.57 & 0.03 & 0.60 \\
\hline 13 & C-D & 12.15 & 0.68 & 12.83 & 1.82 & 0.10 & 1.92 & 0.43 & 0.03 & 0.46 \\
\hline 14 & C-D & 11.05 & 0.68 & 11.73 & 1.65 & 0.10 & 1.75 & 0.39 & 0.03 & 0.42 \\
\hline 15 & C-D & 12.02 & 0.68 & 12.70 & 1.80 & 0.10 & 1.90 & 0.42 & 0.03 & 0.45 \\
\hline 16 & C-D & 4.12 & 0.68 & 4.80 & 0.62 & 0.10 & 0.72 & 0.14 & 0.03 & 0.17 \\
\hline 17 & B-C & 9.77 & 0.68 & 10.45 & 1.46 & 0.10 & 1.56 & 0.34 & 0.03 & 0.37 \\
\hline 18 & A-B & 12.39 & 0.68 & 13.07 & 1.85 & 0.10 & 1.95 & 0.44 & 0.03 & 0.47 \\
\hline 19 & A-B & 12.93 & 0.68 & 13.61 & 1.93 & 0.10 & 2.03 & 0.45 & 0.03 & 0.48 \\
\hline
\end{tabular}

mrem/yr = millirem(s) per year

* The 1994 flyover man-made bins are identified in Figure 8.

NOTE: Results greater than the final action level of 25 millirems per year are identified by bold text. 
TABle 13. Projected Total EfFective Dose RAtes for BLANCA Using Correlated 1994 Flyover Data

\begin{tabular}{|c|c|c|c|c|c|c|c|c|c|}
\hline \multirow[b]{2}{*}{$\begin{array}{c}1994 \\
\text { FLYOVER } \\
\text { MAN-MADE } \\
\text { BIN* }\end{array}$} & \multicolumn{3}{|c|}{ INDUSTRIAL } & \multicolumn{3}{|c|}{ REMOTE WORK } & \multicolumn{3}{|c|}{ OCCASIONAL USE } \\
\hline & $\begin{array}{c}\text { 95\% UCL } \\
\text { EXTERNAL } \\
\text { DOSE } \\
\text { RATE } \\
\text { (mrem/yr) }\end{array}$ & $\begin{array}{c}\text { MAXIMUM } \\
\text { INTERNAL } \\
\text { DOSE } \\
\text { RATE } \\
\text { (mrem/yr) }\end{array}$ & $\begin{array}{c}\text { TOTAL } \\
\text { EFFECTIVE } \\
\text { DOSE } \\
\text { RATE } \\
\text { (mrem/yr) }\end{array}$ & $\begin{array}{c}\text { 95\% UCL } \\
\text { EXTERNAL } \\
\text { DOSE } \\
\text { RATE } \\
\text { (mrem/yr) }\end{array}$ & $\begin{array}{c}\text { MAXIMUM } \\
\text { INTERNAL } \\
\text { DOSE } \\
\text { RATE } \\
\text { (mrem/yr) }\end{array}$ & $\begin{array}{c}\text { TOTAL } \\
\text { EFFECTIVE } \\
\text { DOSE } \\
\text { RATE } \\
\text { (mrem/yr) }\end{array}$ & $\begin{array}{c}\text { 95\% UCL } \\
\text { EXTERNAL } \\
\text { DOSE } \\
\text { RATE } \\
\text { (mrem/yr) }\end{array}$ & $\begin{array}{c}\text { MAXIMUM } \\
\text { INTERNAL } \\
\text { DOSE } \\
\text { RATE } \\
\text { (mrem/yr) }\end{array}$ & $\begin{array}{c}\text { TOTAL } \\
\text { EFFECTIVE } \\
\text { DOSE } \\
\text { RATE } \\
\text { (mrem/yr) }\end{array}$ \\
\hline N/A & 1.08 & 0.68 & 1.76 & 0.16 & 0.10 & 0.26 & 0.04 & 0.03 & 0.07 \\
\hline A-B & 3.00 & 0.68 & 3.68 & 0.45 & 0.10 & 0.55 & 0.11 & 0.03 & 0.14 \\
\hline $\mathrm{B}-\mathrm{C}$ & 5.50 & 0.68 & 6.18 & 0.82 & 0.10 & 0.92 & 0.20 & 0.03 & 0.23 \\
\hline C-D & 9.97 & 0.68 & 10.65 & 1.49 & 0.10 & 1.59 & 0.35 & 0.03 & 0.38 \\
\hline D-E & 16.50 & 0.68 & 17.18 & 2.46 & 0.10 & 2.56 & 0.59 & 0.03 & 0.62 \\
\hline E-F & 25.40 & 0.68 & 26.08 & 3.79 & 0.10 & 3.89 & 0.90 & 0.03 & 0.93 \\
\hline
\end{tabular}

$\mathrm{mrem} / \mathrm{yr}=$ millirem(s) per year

UCL = upper confidence limit

* The 1994 flyover man-made bins are identified in Figure 8.

NOTE: Results greater than the final action level of 25 millirems per year are identified by bold text. 


\subsection{DeViations from the Plan as Approved}

Deviations from the SAFER Plan (NNSA/NSO, 2011) were not required.

\subsection{CoRrective ACTION SCHEDUle AS COMPLETED}

Closure activities began in July 2011 and were completed in December 2011. Details of the schedule are provided in Table 14.

Table 14. Corrective Action Unit 574 Closure Activities Schedule

\begin{tabular}{|l|c|c||}
\hline \multicolumn{1}{|c|}{ ACTIVITY } & START & END \\
\hline \hline Installation of TLDs & July 19, 2011 & July 21, 2011 \\
\hline Retrieval of TLDs & October 20, 2011 & October 20, 2011 \\
\hline Data Analysis & October 24, 2011 & December 8, 2011 \\
\hline
\end{tabular}

\subsection{Site Plan/Survey Plat}

As-built drawings were not required for closure of CAU 574. 
Revision: 0

Date: April 2012

\section{THIS PAGE INTENTIONALLY LEFT BLANK}




\subsection{WASTE DISPOSITION}

No waste was generated during closure of CAU 574 . 
Revision: 0

Date: April 2012

THIS PAGE INTENTIONALLY LEFT BLANK 


\subsection{CLOSURE VERIFICATION RESULTS}

This section provides quality assurance and control measures implemented during sampling and analysis activities conducted for closure of CAU 574 and summarizes the URs implemented.

\subsection{Data Quality Assessment}

The TLD data meet rigorous data quality requirements. The TLDs were obtained from and measured by the NSTec Environmental Technical Services group. This group is responsible for the routine environmental monitoring program at the NNSS (NSTec, 2010).

The TLDs were submitted to the Environmental Technical Services group and analyzed using automated TLD readers calibrated and maintained by the NSTec Radiological Control Department in accordance with existing quality control procedures for TLD processing. Certification is maintained through the U.S. Department of Energy Laboratory Accreditation Program for dosimetry.

Quality assurance procedures for TLD monitoring involve comparing the data from paired TLDs to estimate measurement precision. As shown in Table 15, the paired TLDs at BLANCA show relative percent differences between approximately 3 and 4 percent, which is consistent with results of paired TLDs placed by the NNSS environmental monitoring program.

TABle 15. Thermoluminescent Dosimeter Precision

\begin{tabular}{||c|c|c|}
\hline TLD LOCATION & $\begin{array}{c}\text { NET EXTERNAL } \\
\text { DOSE RATE } \\
\text { (mrem/yr) }\end{array}$ & $\begin{array}{c}\text { PAIRED TLD } \\
\text { RELATIVE } \\
\text { PERCENT } \\
\text { DIFFERENCE }\end{array}$ \\
\hline 7 & 40.78 & \multirow{2}{*}{2.78} \\
\hline 8 & 41.93 & \\
\hline 18 & 12.39 & \multirow{2}{*}{4.27} \\
\hline 19 & 12.93 & \\
\hline
\end{tabular}

mrem/yr = millirem(s) per year

\subsection{USE RESTRICTION}

CAU 574 was closed in place with administrative controls (i.e., URs were implemented). Any use of these areas for activities that are restricted by the URs will require notification of NDEP.

\subsubsection{Corrective Action Site 12-23-10, U12c.03 Crater (Neptune)}

At NEPTUNE, the existing UR for CAU 551 is sufficient to bound contamination above the FAL. Therefore, the UR boundary for CAU 551, as shown in Figure 5, was used for NEPTUNE. The Use Restriction Information form and a figure showing the boundary of the UR area are included in Appendix B of this report. Additional postings were not installed, and annual post-closure inspections will be performed in conjunction with CAU 551. 


\subsubsection{Corrective Action Site 12-45-01, U12e.05 Crater (Blanca)}

At BLANCA, an administrative UR was established as a BMP to restrict any future activities that would result in a site worker exceeding the exposure time assumed under the current land usage. The administrative UR is recorded and controlled in the same manner as a FFACO UR but does not require postings or inspections. Any proposed activity within this area that would change the current land exposure scenario based on a more intensive use of the site would require NDEP approval. Figure 8 shows the boundary of the administrative UR. The Use Restriction Information form and a figure showing the boundary of the administrative UR area are included in Appendix B of this report. 


\subsection{CONCLUSIONS AND RECOMMENDATIONS}

CAU 574 has been closed in accordance with the SAFER Plan (NNSA/NSO, 2011).

\subsection{CONCLUSIONS}

The following investigation and closure activities were performed at CAU 574 as documented in this CR:

- In situ external dose rate measurements were collected using TLDs at BLANCA.

- TED was determined at both sites by summing the internal and external dose rate components.

- A UR was implemented at NEPTUNE. Areas that exceed the FAL of $25 \mathrm{mrem} / \mathrm{yr}$ based on the Occasional Use Area exposure scenario are within the existing UR for CAU 551. The 25-mrem/yr FAL is not exceeded outside the existing UR for any of the exposure scenarios (Industrial Area, Remote Work Area, and Occasional Use Area). Therefore, the existing UR for CAU 551 is sufficient to bound contamination that exceeds the FAL.

- An administrative UR was implemented at BLANCA as a BMP. The 25-mrem/yr FAL was not exceeded for the Remote Work Area or Occasional Use Area exposure scenarios; therefore, a UR is not required. However, because the 25-mrem/yr FAL was exceeded for the Industrial Area exposure scenario, an administrative UR was established as a BMP.

\subsection{Post-Closure REQUiREMENTS}

The post-closure requirements for CAU 574 are described in the following sections.

\subsubsection{Corrective Action Site 12-23-10, U12c.03 Crater (Neptune)}

At NEPTUNE, the existing UR for CAU 551 is sufficient to bound contamination above the FAL. Additional postings were not installed, and annual post-closure inspections will be performed in conjunction with the inspections performed for CAU 551.

\subsubsection{Corrective Action Site 12-45-01, U12e.05 Crater (Blanca)}

At BLANCA, an administrative UR was established as a BMP. The administrative UR does not require postings or inspections.

\subsection{RECOMMENDATIONS}

Because closure activities for CAU 574 have been completed following the SAFER Plan (NNSA/NSO, 2011) as documented in this CR, NNSA/NSO requests the following:

- A Notice of Completion from NDEP to NNSA/NSO for closure of CAU 574

- The transfer of CAU 574 from Appendix III to Appendix IV, Closed Corrective Action Units, of the FFACO 
CAU 574 Closure Report

Section: Conclusions and Recommendations

Revision: 0

Date: April 2012

\section{THIS PAGE INTENTIONALLY LEFT BLANK}




\subsection{REFERENCES}

Federal Facility Agreement and Consent Order, 1996 (as amended March 2010). Agreed to by the State of Nevada; U.S. Department of Energy, Environmental Management; U.S. Department of Defense; and U.S. Department of Energy, Legacy Management.

FFACO, see Federal Facility Agreement and Consent Order.

Los Alamos Scientific Laboratory, 1971. Proceedings of Environmental Plutonium Symposium Held at LASL. LA-4756. Los Alamos Scientific Laboratory: U.S. Atomic Energy Commission.

National Security Technologies, LLC, 2008. Radionuclide Inventory Distribution Project Data Evaluation and Verification White Paper. DOE/NV/25946--994. Las Vegas, NV.

National Security Technologies, LLC, 2010. Nevada Test Site Environmental Report 2009. DOE/NV/25946--1067. Prepared for the U.S. Department of Energy, National Nuclear Security Administration Nevada Site Office. Las Vegas, NV.

NNSA/NSO, see U.S. Department of Energy, National Nuclear Security Administration Nevada Site Office.

NSTec, see National Security Technologies, LLC.

U.S. Department of Energy, National Nuclear Security Administration Nevada Site Office, 2006. Streamlined Approach for Environmental Restoration Plan for Corrective Action Unit 574: Neptune, Nevada National Security Site, Nevada. DOE/NV--1457. Las Vegas, NV.

U.S. Department of Energy, National Nuclear Security Administration Nevada Site Office, 2011. Corrective Action Decision Document/Closure Report for Corrective Action Unit 551: Area 12 Muckpiles, Nevada Test Site, Nevada. DOE/NV--1174-REV 1. Las Vegas, NV. 
CAU 574 Closure Report

Section: References

Revision: 0

Date: April 2012

THIS PAGE INTENTIONALLY LEFT BLANK 


\section{APPENDIX A*}

\section{DATA QUALITY OBJECTIVES}

*As presented and published in the approved Streamlined Approach for Environmental Restoration Plan for Corrective Action Unit 574: Neptune, Nevada National Security Site, Nevada. DOE/NV--1457. Las Vegas, NV. 
CAU 574 Closure Report

Section: Appendix A

Revision: 0

Date: April 2012

THIS PAGE INTENTIONALLY LEFT BLANK 


\subsection{DATA QUALITY OBJECTIVES}

The DQO process is a strategic planning approach based on the scientific method that is designed to ensure that the data collected will provide sufficient and reliable information to identify, evaluate, and technically defend the recommendation of viable corrective actions (U.S. Environmental Protection Agency [EPA], 2006). This section contains a summary of the DQO process that was developed at a meeting with decision makers on May 23, 2011.

\subsection{SUMMARY OF DQO ANALYSIS}

The DQOs are designed to identify data needs, clearly define the intended use of the data, and to design a data collection program that will satisfy these purposes. During the DQO discussions for this CAU, the informational inputs and data needs to resolve the problem statement and decisions were identified and documented.

The problem statement for CAU 574 is: "Existing information is insufficient to determine the extent of contamination and confirm closure of CAU 574.” To address this question, the resolution of two decisions statements is required:

- Decision I: "Is radiological contamination present at concentrations such that the TED rate exceeds the FAL?"

- Decision II: “If radiological contamination is present at concentrations such that the TED rate exceeds the FAL, is sufficient information available to define the extent of contamination that exceeds the FAL?"

If sufficient information is not available to meet the closure objectives, then site conditions will be re-evaluated and additional data will be collected (as long as the scope of the CAI is not exceeded and CSM assumptions have not been shown to be incorrect).

Previous data that have been collected, including analytical soil sample data, aerial radiological survey results, RIDP data, and dose rate measurements, will be evaluated to resolve the decision statements. In addition, new data will be collected to verify the adequacy of existing information, affirm the chosen corrective action, provide sufficient data to implement the corrective action, and confirm that closure objectives were met. Data that will be collected during the SAFER process to support closure of CAU 574 include in situ external dose rate measurements using TLDs at BLANCA.

The population of interest to resolve the decisions includes the spatial boundaries of the sites. This spatial boundary includes, at a minimum, the area(s) of radioactive contamination that could cause a potential dose above action levels, and may include an area as large as the entire watershed that encompasses the site.

The data quality indicators (DQIs) of precision, accuracy, representativeness, completeness, comparability, and sensitivity needed to satisfy DQO requirements are discussed in Section 7.0. Data will be assessed in the CR to confirm or refute the CSM and determine whether the DQO data needs were met. Data collection and analysis methods must be capable of measuring analyte concentrations at or below the corresponding action levels. As appropriate, detection limits will be determined and compared to the action levels described in Section 3.2.1. If detection limits are higher than action levels, the detection limit will be used to make closure decisions. 
The DQO process specifies performance criteria for the decision rules. Setting tolerable limits on decision errors requires the planning team to weigh the relative effects of threats to human health and the environment, expenditure of resources, and the consequences of an incorrect decision. In general, confidence in DQO decisions will be established by the following:

- Developing a CSM

- Testing the validity of the CSM based on data analysis

- Evaluating the quality of the data based on DQI parameters

\subsection{RESULTS OF THE DQO ANALYSIS}

The problem statement, "Existing information is insufficient to determine the extent of contamination and confirm closure of CAU 574," will be resolved through an evaluation of available characterization data and the collection and evaluation of additional data to define the extent of contamination that exceeds the FAL.

At NEPTUNE, available characterization data are sufficient to resolve the decisions by calculating internal and external dose rates to determine the TED rates, comparing the TED rates to the FAL, defining the extent of contamination exceeding the FAL, and delineating a UR boundary.

At BLANCA, additional data will be collected with TLDs to determine the external dose rate component of TED at the site, and available characterization data will be used to calculate internal dose rates. The TED rates will then be determined and compared to the FAL, the extent of contamination exceeding the FAL will be defined, and a UR boundary will be delineated.

\subsubsection{Action Level Determination and Basis}

The action levels for radiological contaminants are based on the screening limits recommended in the National Council on Radiation Protection (NCRP) Report No. 129 for construction, commercial, industrial land use scenarios (NCRP, 1999) using a 25-mrem/yr dose constraint (Murphy, 2004) and the generic guidelines for residual concentration of radionuclides in DOE O 5400.5 (DOE, 1993).

The FAL for CAU 574 is a TED rate of 25 mrem/yr based on the Occasional Use Area exposure scenario, which is defined as workers being exposed to the site occasionally, up to 80 hours per year for 5 years. The TED rate is determined by summing the internal and external dose components.

The Residual Radioactive (RESRAD) computer code has been used to derive RRMGs for the internal dose component for each radionuclide. The RRMGs are the activity concentrations of individual radionuclides in surface soil that would cause a receptor to receive an internal dose equal to the FAL of $25 \mathrm{mrem} / \mathrm{yr}$ under the conditions described in a given exposure scenario. The CAU 551 soil sample results listed in Table 1 will be compared to the RRMGs using the sum of the fractions approach to calculate internal dose rates at NEPTUNE.

Table 2 lists the RRMGs calculated for each exposure scenario (Industrial Area, Remote Work Area, and Occasional Use Area). The RESRAD code variables (i.e., input parameters) used to calculate the RRMGs are listed in Table 3. 
TABle 2. RESIDUAL RADIOACTIVE MATERIAL GUIDElines DeRIVED FOR CORRECTIVE ACTION UNIT 574

\begin{tabular}{|c|c|c|c|c|c|c|}
\hline \multirow{2}{*}{ Radionuclide } & \multicolumn{5}{|c|}{ RRMG (pCi/g) } \\
\cline { 2 - 7 } & \multicolumn{3}{|c|}{ NEPTUNE } & \multicolumn{3}{c||}{ BLANCA } \\
\cline { 2 - 7 } & Industrial & $\begin{array}{c}\text { Remote } \\
\text { Work }\end{array}$ & $\begin{array}{c}\text { Occasional } \\
\text { Use }\end{array}$ & Industrial & $\begin{array}{c}\text { Remote } \\
\text { Work }\end{array}$ & $\begin{array}{c}\text { Occasional } \\
\text { Use }\end{array}$ \\
\hline \hline americium-241 & 350 & 1,334 & 5,611 & 341 & 1,281 & 5,387 \\
\hline cobalt-60 & 98,590 & 600,300 & $2,525,000$ & 105,800 & 652,500 & $2,744,000$ \\
\hline cesium-137 & 53,650 & 355,900 & $1,497,000$ & 58,490 & 401,100 & $1,687,000$ \\
\hline europium-152 & 323,200 & $1,615,000$ & $6,793,000$ & 332,700 & $1,638,000$ & $6,891,000$ \\
\hline europium-154 & 228,800 & $1,172,000$ & $4,928,000$ & 236,800 & $1,198,000$ & $5,037,000$ \\
\hline europium-155 & $1,502,000$ & $7,835,000$ & $32,950,000$ & $1,561,000$ & $8,055,000$ & $33,880,000$ \\
\hline plutonium-238 & 398 & 1,516 & 6,378 & 383 & 1,434 & 6,030 \\
\hline plutonium-239 & 360 & 1,376 & 5,788 & 347 & 1,302 & 5,475 \\
\hline plutonium-240 & 360 & 1,376 & 5,788 & 347 & 1,302 & 5,475 \\
\hline strontium-90 & 16,410 & 99,480 & 418,400 & 17,770 & 109,000 & 458,600 \\
\hline \hline
\end{tabular}

$\mathrm{pCi} / \mathrm{g}=$ picocurie(s) per gram

RRMG = Residual Radioactive Material Guideline 
TABle 3. Residual Radioactive Computer Code InPut Parameters

\begin{tabular}{|c|c|c|c|c|c|c|c|c|}
\hline \multirow{3}{*}{ Parameter } & \multirow{3}{*}{ Unit } & \multicolumn{6}{|c|}{ Parameter Value } & \multirow{3}{*}{ Comments/Basis } \\
\hline & & \multicolumn{2}{|c|}{ Industrial } & \multicolumn{2}{|c|}{ Remote Work } & \multicolumn{2}{|c|}{ Occasional Use } & \\
\hline & & NEPTUNE & BLANCA & NEPTUNE & BLANCA & NEPTUNE & BLANCA & \\
\hline Area of CZ & $\mathrm{m}^{2}$ & 70,000 & 680,000 & 70,000 & 680,000 & 70,000 & 680,000 & $\begin{array}{l}\text { Based on actual area. RESRAD is } \\
\text { sensitive to differences in area in the range } \\
\text { of the default value selected. The effect } \\
\text { on using the actual site area is to lower the } \\
\text { RRMGs. }\end{array}$ \\
\hline Thickness of CZ & $\mathrm{m}$ & 1.0 & 0.05 & 1.0 & 0.05 & 1.0 & 0.05 & $\begin{array}{l}\text { NEPTUNE based on CAU } 551 \text { data; } \\
\text { BLANCA based on Soils Sub-Project } \\
\text { assumptions. }\end{array}$ \\
\hline Density of CZ & $\mathrm{g} / \mathrm{cm}^{3}$ & 1.5 & 1.5 & 1.5 & 1.5 & 1.5 & 1.5 & NNSA/NSO, 2006b \\
\hline CZ Erosion Rate & $\mathrm{m} / \mathrm{yr}$ & 0.001 & 0.001 & 0.001 & 0.001 & 0.001 & 0.001 & NNSA/NSO, 2006b \\
\hline CZ Total Porosity & & 0.4 & 0.4 & 0.4 & 0.4 & 0.4 & 0.4 & NNSA/NSO, 2006b \\
\hline CZ Field Capacity & & 0.2 & 0.2 & 0.2 & 0.2 & 0.2 & 0.2 & NNSA/NSO, 2006b \\
\hline $\begin{array}{l}\text { CZ Hydraulic } \\
\text { Conductivity }\end{array}$ & $\mathrm{m} / \mathrm{yr}$ & 10 & 10 & 10 & 10 & 10 & 10 & NNSA/NSO, 2006b \\
\hline CZ b Parameter & & 5.3 & 5.3 & 5.3 & 5.3 & 5.3 & 5.3 & NNSA/NSO, 2006b \\
\hline $\begin{array}{l}\text { Average Annual } \\
\text { Wind Speed }\end{array}$ & $\mathrm{m} / \mathrm{s}$ & 4.07 & 4.07 & 4.07 & 4.07 & 4.07 & 4.07 & NNSA/NSO, 2006b \\
\hline $\begin{array}{l}\text { Evapotranspiration } \\
\text { Coefficient }\end{array}$ & & 0.5 & 0.5 & 0.5 & 0.5 & 0.5 & 0.5 & NNSA/NSO, 2006b \\
\hline Precipitation & $\mathrm{m} / \mathrm{yr}$ & 0.1626 & 0.1626 & 0.1626 & 0.1626 & 0.1626 & 0.1626 & Site-specific \\
\hline Runoff Coefficient & & 0.4 & 0.4 & 0.4 & 0.4 & 0.4 & 0.4 & NNSA/NSO, 2006b \\
\hline Inhalation Rate & $\mathrm{m}^{3} / \mathrm{yr}$ & 8,400 & 8,400 & 12,300 & 12,300 & 12,300 & 12,300 & NNSA/NSO, 2006b \\
\hline $\begin{array}{l}\text { Mass Loading for } \\
\text { Inhalation }\end{array}$ & $\mathrm{g} / \mathrm{m}^{3}$ & 0.0006 & 0.0006 & 0.0006 & 0.0006 & 0.0006 & 0.0006 & NNSA/NSO, 2006b \\
\hline Exposure Duration & $\mathrm{yr}$ & 25 & 25 & 25 & 25 & 25 & 25 & NNSA/NSO, 2006b \\
\hline $\begin{array}{l}\text { Shielding Factor } \\
\text { Inhalation }\end{array}$ & & 0.4 & 0.4 & 0.4 & 0.4 & 0.4 & 0.4 & $\begin{array}{l}\text { RESRAD default is based on typical } \\
\text { building construction and ventilation } \\
\text { methods. }\end{array}$ \\
\hline $\begin{array}{l}\text { Shielding Factor } \\
\text { External Gamma }\end{array}$ & & N/A & $\mathrm{N} / \mathrm{A}$ & $\mathrm{N} / \mathrm{A}$ & N/A & $\mathrm{N} / \mathrm{A}$ & $\mathrm{N} / \mathrm{A}$ & $\begin{array}{l}\text { Not applicable; external gamma pathway } \\
\text { is not in use. }\end{array}$ \\
\hline
\end{tabular}


Table 3. Residual Radioactive Computer Code InPut Parameters (CONTINued)

\begin{tabular}{|c|c|c|c|c|c|c|c|c|}
\hline \multirow{3}{*}{ Parameter } & \multirow{3}{*}{ Unit } & \multicolumn{6}{|c|}{ Parameter Value } & \multirow{3}{*}{ Comments/Basis } \\
\hline & & \multicolumn{2}{|c|}{ Industrial } & \multicolumn{2}{|c|}{ Remote Work } & \multicolumn{2}{|c|}{ Occasional Use } & \\
\hline & & NEPTUNE & BLANCA & NEPTUNE & BLANCA & NEPTUNE & BLANCA & \\
\hline $\begin{array}{l}\text { Fraction of Time } \\
\text { Spent Indoors }\end{array}$ & & 0.171 & 0.171 & N/A & N/A & N/A & N/A & $\begin{array}{l}\text { Industrial is based on current Soils } \\
\text { Sub-Project procedures and assumptions; } \\
\text { Remote Work and Occasional Use assume } \\
\text { all hours are outdoors. }\end{array}$ \\
\hline $\begin{array}{l}\text { Fraction of Time } \\
\text { Spent Outdoors }\end{array}$ & & 0.0856 & 0.0856 & 0.0384 & 0.0384 & 0.00913 & 0.00913 & $\begin{array}{l}\text { Industrial is based on current Soils } \\
\text { Sub-Project procedures and assumptions; } \\
\text { Remote Work and Occasional Use assume } \\
\text { all hours are outdoors. }\end{array}$ \\
\hline Shape Factor & & 1 & 1 & 1 & 1 & 1 & 1 & Assumed circular deposition. \\
\hline Soil Ingestion Rate & $\mathrm{g} / \mathrm{yr}$ & 36.5 & 36.5 & 36.5 & 36.5 & 36.5 & 36.5 & $\begin{array}{l}\text { RESRAD applies occupancy factor } \\
\text { corrections to this value through } \\
\text { calculation; the value should not be } \\
\text { corrected prior to input (NNSA/NSO, } \\
\text { 2006b [ } 480 \mathrm{mg} / \text { day]). }\end{array}$ \\
\hline Depth of Mixing & $\mathrm{m}$ & .15 & .056 & .15 & .056 & .15 & .056 & $\begin{array}{l}\text { RESRAD default for NEPTUNE due to } \\
\text { man-made disturbance of the area; } \\
\text { BLANCA relies upon Soils Sub-Project } \\
\text { assumption that } 90 \text { percent of } \\
\text { contaminants are in the top } 5 \mathrm{~cm} \text { of soil. }\end{array}$ \\
\hline
\end{tabular}

CAU $=$ Corrective Action Unit $\mathrm{cm}=$ centimeter(s)

$\mathrm{CZ}=$ contamination zone

$\mathrm{g} / \mathrm{cm}^{3}=$ gram(s) per cubic centimeter

$\mathrm{g} / \mathrm{m}^{3}=$ gram(s) per cubic meter

$\mathrm{g} / \mathrm{yr}=\operatorname{gram}(\mathrm{s})$ per year

$\mathrm{m}=$ meter(s)

$\mathrm{m}^{2}=$ square meter(s)

$\mathrm{m}^{3} / \mathrm{yr}=$ cubic meter(s) per year $\mathrm{m} / \mathrm{s}=$ meter(s) per second

$\mathrm{m} / \mathrm{yr}=$ meter(s) per year

$\mathrm{mg} /$ day = milligram(s) per day

NNSA/NSO = U.S. Department of Energy, National Nuclear Security Administration Nevada Site Office

N/A = not applicable

RESRAD = Residual Radioactive

RRMG = Residual Radioactive Material Guideline

$\mathrm{yr}=$ year $(\mathrm{s})$ 


\subsubsection{Hypothesis Test}

The baseline condition (i.e., null hypothesis) and alternative condition are:

- Baseline condition - closure objectives have not been met.

- Alternative condition - closure objectives have been met.

The closure objective is to define the extent of contamination that exceeds the FAL to define a UR. Sufficient evidence to reject the null hypothesis is the identification of the extent of contamination.

\subsubsection{Statistical Model}

A judgmental measurement scheme will be implemented to select in situ external dose rate measurement (TLD) locations at BLANCA and evaluate DQO decisions. Each measurement will be compared to fixed threshold values (i.e., FALs) on a point-by-point basis to determine the appropriate resolution to the decisions; therefore, a statistical model does not apply to the measurement scheme for CAU 574.

\subsubsection{Design Description/Option}

A judgmental design will be used to select locations for collection of in situ external dose rate measurements at BLANCA. Because individual measurements, rather than an average, will be compared to the FAL, statistical methods will not be used. Adequate representativeness of the entire target population is not a requirement because good prior information is available for BLANCA, as discussed in Section 2.2.4. Therefore, the measurement scheme is designed to collect measurements from areas known to have the highest levels of contamination. If the observed measurements are below the action level, then a decision can be made without the samples being truly representative of the entire area (EPA, 2006).

In situ external dose rate measurement (TLD) locations will be selected to satisfy the DQI of representativeness in that selected locations will best represent the populations of interest and target areas with the highest potential for contamination. TLD locations will be determined based on process knowledge and the results of the 1994 aerial radiological (flyover) survey. Section 4.2.2.1 provides additional details on the collection of external dose rate measurements and the placement of TLDs at BLANCA.

\subsubsection{Conceptual Site Model}

The CSM describes the most probable scenario for current conditions at the site and defines the assumptions that are the basis for identifying the future land use, contaminant sources, release mechanisms, migration pathways, and exposure routes and for choosing a conceptual CAA. The CSM is based on physical setting, potential contaminant sources, release information, historical documentation, personnel interviews, process knowledge, site visits, photographs, field screening, and analytical results. The CSM was used to develop appropriate sampling strategies and data collection methods. The CSM for these sites is summarized in Table 4.

If evidence of contamination that is not consistent with the CSM is identified during CAI activities, the situation will be reviewed, the CSM will be revised, the DQOs will be reassessed, and a recommendation will be made as to how best to proceed. In such cases, participants in the DQO process will be notified and given the opportunity to comment on and/or concur with the recommendation. 
Table 4. Conceptual Site Model for Corrective Action Unit 574

\begin{tabular}{|c|c|c|}
\hline CSM Element & $\begin{array}{c}\text { CAS 12-23-10 } \\
\text { U12c.03 Crater (Neptune) }\end{array}$ & $\begin{array}{c}\text { CAS 12-45-01 } \\
\text { U12e.05 Crater (Blanca) }\end{array}$ \\
\hline Site Status & \multicolumn{2}{|l|}{ Inactive and/or abandoned } \\
\hline Land Use Zone & \multicolumn{2}{|c|}{$\begin{array}{l}\text { Nuclear Test Zone: This area is reserved for dynamic experiments, } \\
\text { hydrodynamic tests, and underground nuclear weapons and weapons effects } \\
\text { tests. This zone includes compatible defense and nondefense research, } \\
\text { development, and testing activities. }\end{array}$} \\
\hline Exposure Scenario & \multicolumn{2}{|c|}{$\begin{array}{l}\text { Occasional Use Area: Worker will be exposed to the site occasionally (up to } \\
80 \text { hours per year for } 5 \text { years). Site structures are not present for shelter and } \\
\text { comfort of the worker. }\end{array}$} \\
\hline $\begin{array}{l}\text { Sources of Potential Soil } \\
\text { Contamination }\end{array}$ & \multicolumn{2}{|c|}{ Fallout and soil activation from venting of underground nuclear testing } \\
\hline Impacted Media & \multicolumn{2}{|l|}{ Surface and subsurface soil } \\
\hline Potential Contaminants & \multicolumn{2}{|l|}{ Radionuclides } \\
\hline Extent of Contamination & \multicolumn{2}{|c|}{$\begin{array}{l}\text { Contamination, if present, is expected to be contiguous to the release points. } \\
\text { Concentrations are expected to decrease with distance from the source. } \\
\text { Groundwater contamination is not expected. }\end{array}$} \\
\hline Transport Mechanisms & \multicolumn{2}{|c|}{$\begin{array}{l}\text { Surface water runoff may provide for the transportation of some } \\
\text { contaminants within or outside of the boundaries of the CASs. There is a } \\
\text { known watershed at the CASs. Infiltration of precipitation through } \\
\text { subsurface media serves as a minor driving force for migration of } \\
\text { contaminants. Ejection of material from the craters provided a transport } \\
\text { mechanism at detonation. }\end{array}$} \\
\hline Migration Pathways & \multicolumn{2}{|c|}{$\begin{array}{l}\text { Lateral transport (runoff) is expected to dominate over vertical transport } \\
\text { (infiltration) due to limited vertical infiltration. The sites are located within } \\
\text { a known watershed that collects down slope to the southeast either within } \\
\text { the existing UR for CAU } 551 \text { or in the Radioactive Material Area located to } \\
\text { the southeast of the existing UR. The area is subject to infrequent, } \\
\text { potentially intense, stormwater flows that provide an intermittent mechanism } \\
\text { for both vertical and horizontal transport of contaminants. Contaminated } \\
\text { sediments entrained by these stormwater events would be carried by the } \\
\text { streamflow to locations where the flowing water loses energy and the } \\
\text { sediments drop out. }\end{array}$} \\
\hline $\begin{array}{l}\text { Lateral and Vertical Extent of } \\
\text { Contamination }\end{array}$ & \multicolumn{2}{|c|}{$\begin{array}{l}\text { Subsurface contamination is assumed to be present in the NEPTUNE crater } \\
\text { and in the location where the BLANCA test vented. Contamination is } \\
\text { expected to be contiguous to the release points. Concentrations are expected } \\
\text { to decrease with distance and depth from the source. Groundwater } \\
\text { contamination is not expected. Lateral and vertical extent of COC } \\
\text { contamination is assumed to be within the spatial boundaries of the CAS. }\end{array}$} \\
\hline Exposure Pathways & \multicolumn{2}{|c|}{$\begin{array}{l}\text { The potential for contamination exposure is limited to industrial and } \\
\text { construction workers, and military personnel conducting training. These } \\
\text { human receptors may be exposed through inhalation or incidental ingestion } \\
\text { of soil due to inadvertent disturbance of materials or through irradiation by } \\
\text { radioactive materials. }\end{array}$} \\
\hline
\end{tabular}


CAU 574 SAFER Plan

Section: Data Quality Objectives

Revision: 0

Date: August 2011

THIS PAGE INTENTIONALLY LEFT BLANK 
Revision: 0

Date: April 2012

\section{APPENDIX B}

\section{USE RESTRICTION DOCUMENTATION}


CAU 574 Closure Report

Section: Appendix B

Revision: 0

Date: April 2012

\section{THIS PAGE INTENTIONALLY LEFT BLANK}




\section{Use Restriction Information}

CAU Number/Description: $\underline{\text { CAU 574/Neptune }}$

Applicable CAS Number/Description: CAS 12-23-10/U12c.03 Crater (Neptune)

Contact (Federal Sub-Project Director/Sub-Project): Kevin J. Cabble/Soils

FFACO Use Restriction Physical Description:

Surveyed Area (UTM, Zone 11, NAD 83, meters):

\begin{tabular}{|c|c|c|}
\hline UR Point & Northing & Easting \\
\hline Southernmost Point & $4,116,172.64$ & $571,421.45$ \\
\hline Northwest Corner & $4,116,595.54$ & $570,926.74$ \\
\hline South D-Tunnel Portal & $4,116,620.94$ & $570,936.94$ \\
\hline West D-Tunnel Portal & $4,116,629.04$ & $570,929.64$ \\
\hline East D-Tunnel Portal & $4,116,632.64$ & $570,937.04$ \\
\hline SE D-Tunnel Portal & $4,116,627.64$ & $570,944.84$ \\
\hline East F-Tunnel Portal & $4,116,649.84$ & $570,973.25$ \\
\hline Near C-Tunnel Portal & $4,116,665.74$ & $570,974.35$ \\
\hline East C-Tunnel Portal & $4,116,666.94$ & $570,981.15$ \\
\hline Along C-Tunnel Road & $4,116,659.94$ & $570,996.35$ \\
\hline Along C-Tunnel Road & $4,116,665.74$ & $571,015.55$ \\
\hline Along C-Tunnel Road & $4,116,685.95$ & $571,045.95$ \\
\hline Northern Point & $4,116,723.15$ & $571,041.65$ \\
\hline Northeast Corner & $4,116,728.25$ & $571,053.85$ \\
\hline NW of B-Tunnel Portal & $4,116,669.75$ & $571,075.35$ \\
\hline North B-Tunnel Portal & $4,116,676.75$ & $571,092.15$ \\
\hline East B-Tunnel Portal & $4,116,648.55$ & $571,100.55$ \\
\hline Along Access Road & $4,116,640.35$ & $571,116.85$ \\
\hline Along Access Road & $4,116,653.85$ & $571,134.15$ \\
\hline Along Access Road & $4,116,664.35$ & $571,146.55$ \\
\hline Along Access Road & $4,116,668.45$ & $571,160.55$ \\
\hline Along Access Road & $4,116,660.35$ & $571,183.95$ \\
\hline Along Access Road & $4,116,622.25$ & $571,255.25$ \\
\hline Along Access Road & $4,116,601.95$ & $571,308.45$ \\
\hline Along Access Road & $4,116,540.14$ & $571,405.05$ \\
\hline Along Access Road & $4,116,522.94$ & $571,411.25$ \\
\hline Along Access Road & $4,116,522.54$ & $571,402.15$ \\
\hline Along Access Road & $4,116,547.74$ & $571,344.25$ \\
\hline Along Access Road & $4,116,546.24$ & $571,322.45$ \\
\hline North of Road & $4,116,367.14$ & $571,342.35$ \\
\hline Northwest of Road & $4,116,357.64$ & $571,326.65$ \\
\hline Along Access Road & $4,116,343.04$ & $571,335.65$ \\
\hline Along Access Road & $4,116,310.74$ & $571,342.65$ \\
\hline Along Access Road & $4,116,195.14$ & $571,425.75$ \\
\hline
\end{tabular}

Depth: No depth limitations

Survey Source (GPS, GIS, etc): $\underline{\text { GIS }}$ 


\section{Basis for FFACO UR:}

Summary Statement: This FFACO use restriction (UR) was implemented to protect site workers from inadvertent exposure. Data indicate that a worker could potentially receive a 25-millirem-per-year dose under the current exposure scenario. The current exposure scenario is Occasional Use, which assumes occasional activities at the site and exposure to workers who are not assigned to the area but may occasionally use the site. A worker under this scenario is assumed to be on site for 80 hours ( 10 days) per year for 5 years.

Personnel are restricted from performing activities other than short-term activities within the UR. Permissible short-term activities include site visits, inspections, monitoring activities, sample collection, sign maintenance, radiological surveys, short-duration radiological training, and retrieval of objects from within the use-restricted area. Any activities to be conducted within this area that are not consistent with these defined short-term activities require the prior notification and approval of the NDEP.

\section{Contaminants Table:}

\begin{tabular}{|c|c|c|c|}
\hline \multicolumn{4}{|c||}{ Maximum Concentration of Contaminants for CAU 574 } \\
CAS 12-23-10, U12c.03 Crater (Neptune) \\
\hline Constituent & Maximum Dose & Action Level & Units \\
\hline Total Effective Dose & 33.73 & 25 & mrem/80 hours \\
\hline
\end{tabular}

Site Controls: CAU 551 UR warning signs

\section{UR Maintenance Requirements:}

Description: Annual post-closure inspections will be performed in conjunction with the inspections performed for CAU 551. This UR must be entered into the NNSA/NSO Facility Information Management System (FIMS) and FFACO databases.

\section{Inspection/Maintenance Frequency: Annual}

The future use of any land related to this Corrective Action Unit (CAU), as described by the above surveyed location, is restricted from any DOE or Air Force activity that may alter or modify the containment control as approved by the State and identified in the CAU CR or other CAU documentation unless appropriate concurrence is obtained in advance.

Comments: See the Closure Report for additional information on the condition of the site.

Submitted By:
Date: 


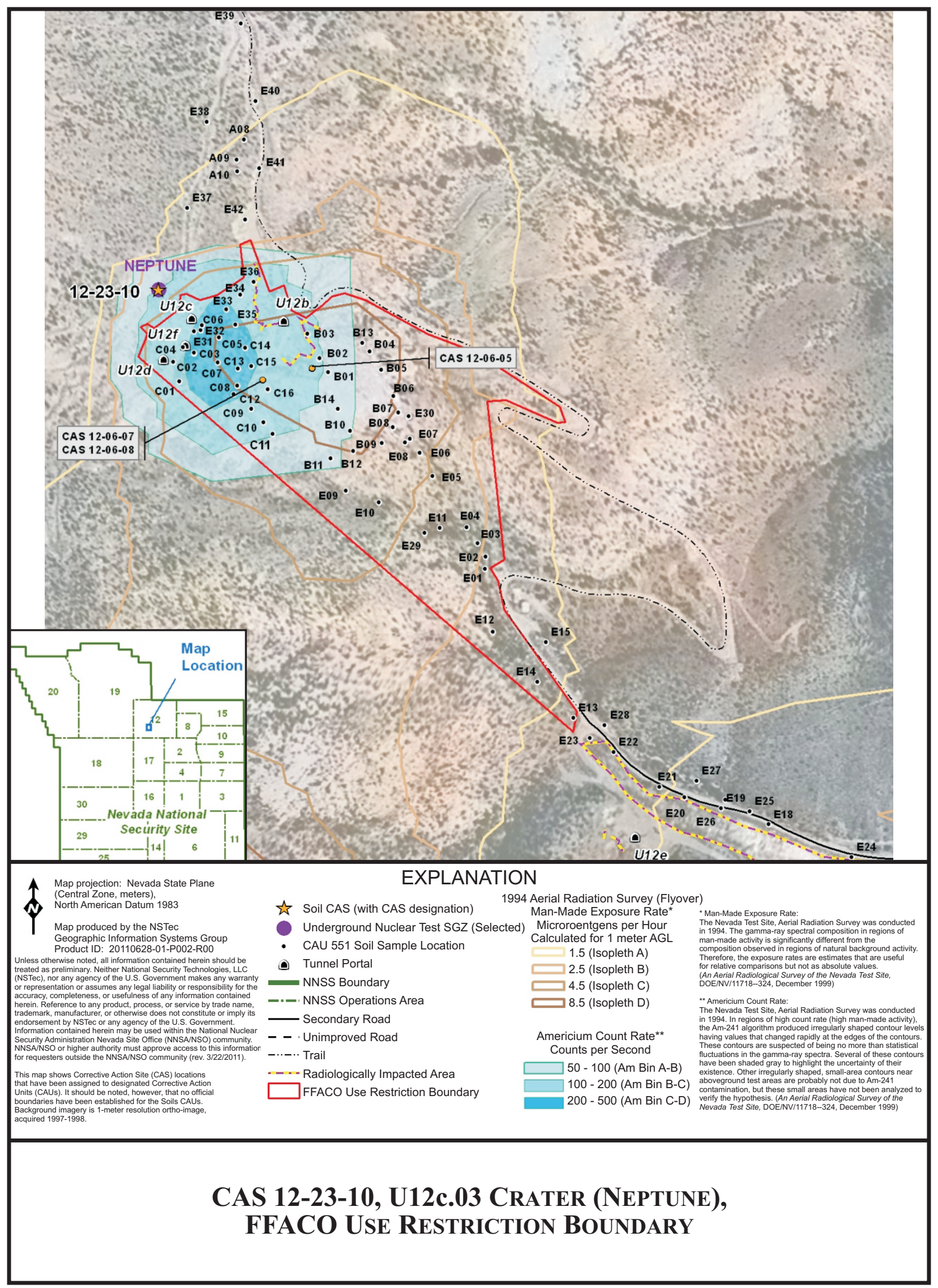


CAU 574 Closure Report

Section: Appendix B

Revision: 0

Date: April 2012

\section{THIS PAGE INTENTIONALLY LEFT BLANK}




\section{Use Restriction Information}

CAU Number/Description: CAU 574/Neptune

Applicable CAS Number/Description: CAS 12-45-01/U12e.05 Crater (Blanca)

Contact (Federal Sub-Project Director/Sub-Project): Kevin J. Cabble/Soils

Administrative Use Restriction Physical Description:

Surveyed Area (UTM, Zone 11, NAD 83, meters):

\begin{tabular}{|c|c|c|}
\hline \hline UR Point & Northing & Easting \\
\hline 1 & $4,115,741.76$ & $571,099.14$ \\
\hline 2 & $4,115,661.87$ & $570,914.98$ \\
\hline 3 & $4,115,844.67$ & $570,585.93$ \\
\hline 4 & $4,116,035.60$ & $570,617.08$ \\
\hline 5 & $4,116,120.91$ & $570,893.32$ \\
\hline 6 & $4,116,065.39$ & $571,047.69$ \\
\hline 7 & $4,115,892.07$ & $571,181.76$ \\
\hline
\end{tabular}

Depth: No depth limitations

Survey Source (GPS, GIS, etc): $\underline{\text { GIS }}$

\section{Basis for Administrative UR:}

Summary Statement: This administrative use restriction (UR) was implemented to protect site workers from inadvertent exposure. Data indicate that a worker could potentially receive a 25-millirem-per-year dose if activities in the area result in a more intensive use of the site. The current exposure scenario at this site does not assume site workers to be present for the amount of time that would result in a 25-millirem-per-year dose. However, the administrative UR will prevent a future more intensive use of the area such that the exposure scenario for the site becomes Industrial, which assumes continuous industrial use of the site and daily exposure to workers during an average workday. The Industrial Area exposure scenario assumes that the site is the regularly assigned work area for a worker for an entire career (225 days per year, 10 hours per day for 25 years).

Personnel are restricted from performing activities within the UR that would result in a more intensive use of the site than the current exposure scenario assumes. Activities included in the current exposure scenario include short-term activities such as site visits, inspections, monitoring activities, sample collection, radiological surveys, short-duration radiological training, and retrieval of objects within the use-restricted area. Any activities to be conducted within this area that are not consistent with the current defined exposure scenario require the prior notification and approval of the NDEP.

Contaminants Table:

\begin{tabular}{|c|c|c|c|}
\hline \multicolumn{4}{|c|}{ Maximum Concentration of Contaminants for CAU 574 } \\
CAS 12-45-01, U12e.05 Crater (Blanca) \\
\hline \hline Constituent & Maximum Dose & Action Level & Units \\
\hline Total Effective Dose & 42.23 & 25 & $\mathrm{mrem} / 2,250$ hours \\
\hline
\end{tabular}

Site Controls: None 
UR Maintenance Requirements:

Description: This UR must be entered into the NNSA/NSO Facility Information Management System (FIMS) and FFACO databases.

Inspection/Maintenance Frequency: N/A

The future use of any land related to this Corrective Action Unit (CAU), as described by the above surveyed location, is restricted from any DOE or Air Force activity that may alter or modify the containment control as approved by the State and identified in the CAU CR or other CAU documentation unless appropriate concurrence is obtained in advance.

Comments: See the Closure Report for additional information on the condition of the site.

Submitted By: /s/: Kevin Cabble

Date:

$4-25-12$ 


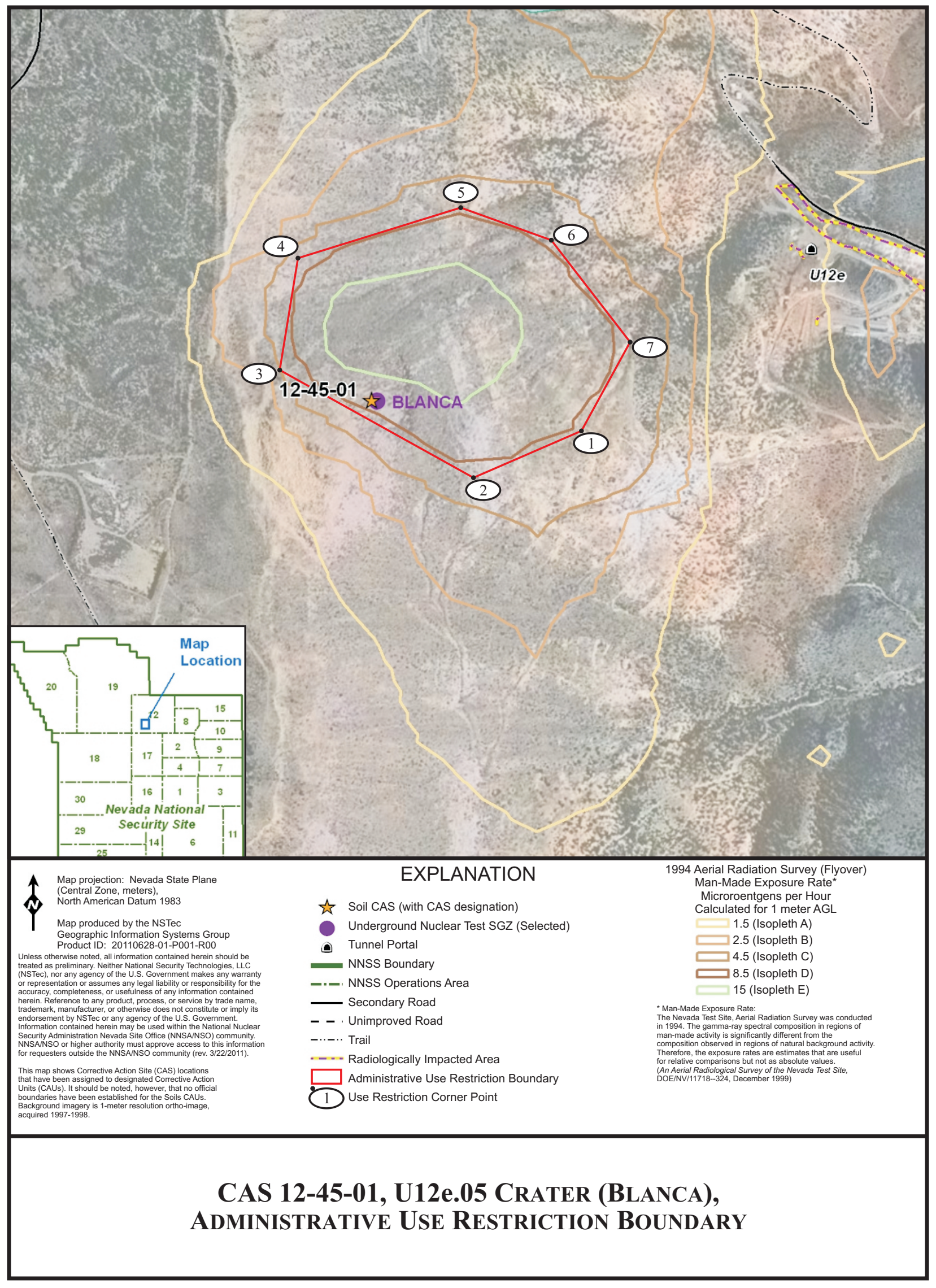


CAU 574 Closure Report

Section: Appendix B

Revision: 0

Date: April 2012

\section{THIS PAGE INTENTIONALLY LEFT BLANK}




\section{APPENDIX C}

\section{RIDP DATA EVALUATION AND VERIFICATION WHITE PAPER}


CAU 574 Closure Report

Section: Appendix C

Revision: 0

Date: April 2012

\section{THIS PAGE INTENTIONALLY LEFT BLANK}




\section{National Security Technologies LLC}

\section{RADIONUCLIDE INVENTORY DISTRIBUTION Project Data Evaluation and Verification WHITE PAPER}

DECEMBER 2008 


\section{DISCLAIMER}

Reference herein to any specific commercial product, process, or service by trade name, trademark, manufacturer, or otherwise, does not necessarily constitute or imply its endorsement, recommendation, or favoring by the U.S. Government or any agency thereof. 


\section{TABLE OF CONTENTS}

ACRONYMS AND ABBREVIATIONS................................................................................................. iv

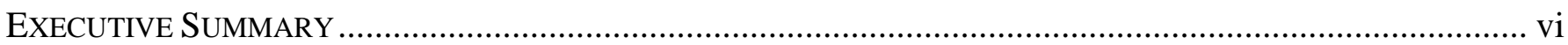

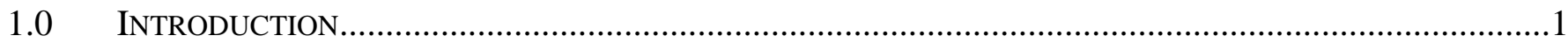

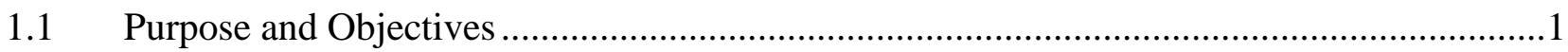

$1.2 \quad$ Scope

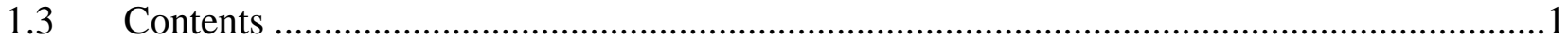

2.0 BACKGROUND

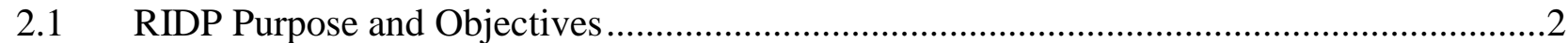

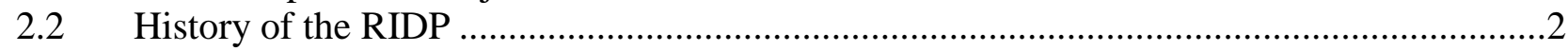

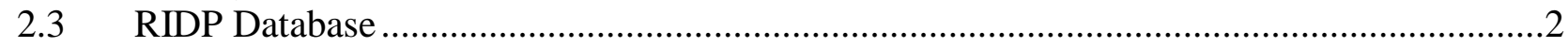

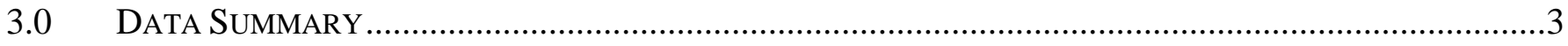

3.1 Aerial Radiological Surveys .......................................................................................

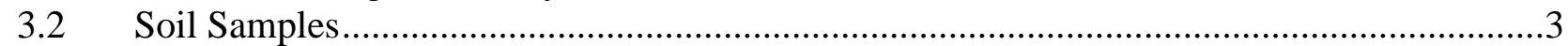

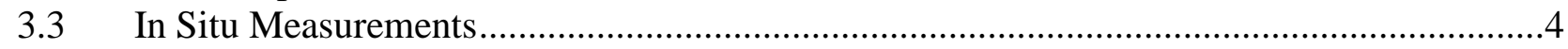

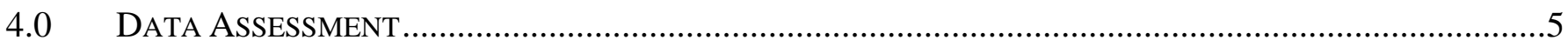

4.1 Pilot Measurements and Project Improvements.................................................................6

4.2 Calibration Analysis.....................................................................................................

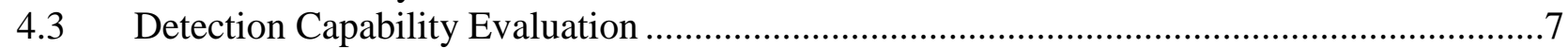

$4.4 \quad$ Duplicate Measurement Quality ………………................................................................

4.5 Quality Control Measurement Analysis...................................................................................

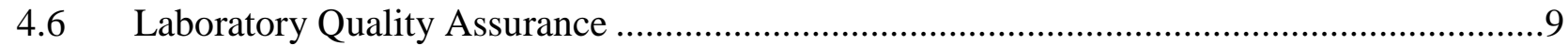

4.7 Comparisons to Other Data Sets ……………...........................................................11

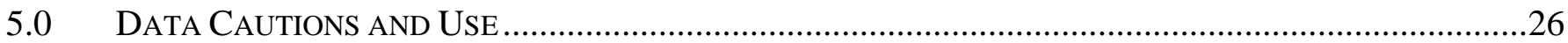

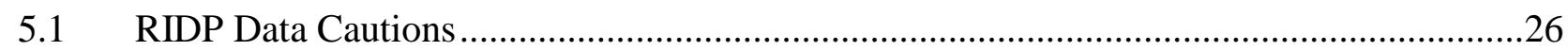

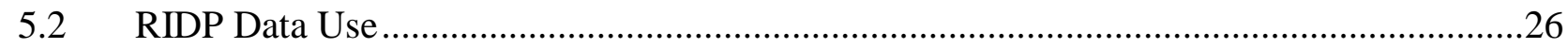

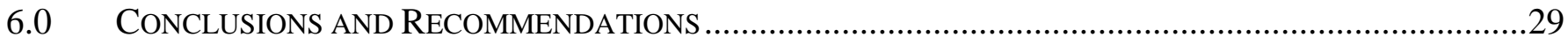

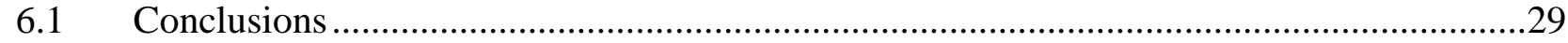

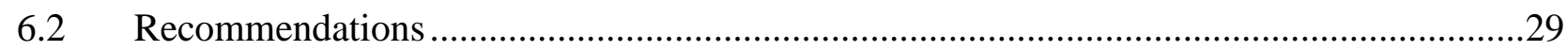

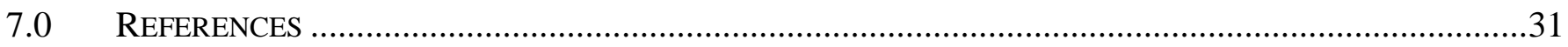

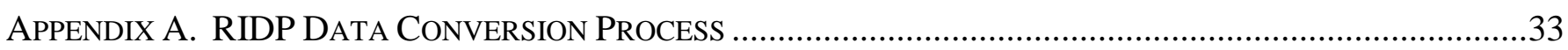

\section{LIST OF FIGURES}

Figure 1. Vehicle Used to Collect In Situ MEASUREMENTS ..............................................................

Figure 2. 1994 Aerial Radiological Survey Data Compared to RIDP Results For Am-241.......12

Figure 3. 1994 Aerial Radiological Survey Data Compared to RidP Results For Total

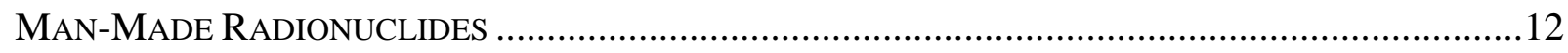

FIGURE 4. CAU 370 CAI RESULTS FOR AM-241 COMPARED TO RIDP DATA ..............................................13 


\section{TABLE OF CONTENTS, CONTINUED}

FigURE 5. CAU 370 CAI RESUltS FOR PU-238 COMPARED TO RIDP DATA ..........................................14

Figure 6. CAU 370 CAI RESUltS FOR PU-239 COMPARED TO RIDP DATA ........................................14

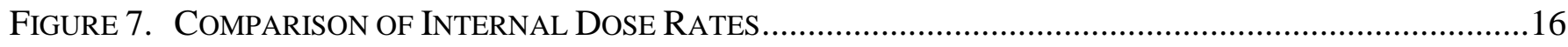

Figure 8. CAU 370 TLD Results Compared to CAU 370 SoIl SAMPLE Results..............................19

FIgURE 9. CAU 370 TLD RESUlTs COMPARED TO CONVERTED RIDP DATA .......................................20

Figure 10. CAU 370 TLD RESUltS COMPARED TO RIDP DATA USING BECK (1980) CONVERSION

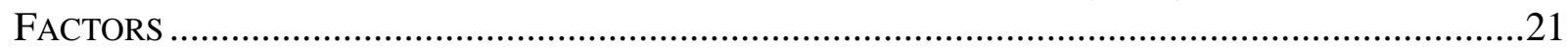

Figure 11. CAU 370 TLD RESUltS COMPARED TO RIDP DATA USING ANSPAUGH AND DANIELS (1995) DOSE-BASED LIMITS

Figure 12. CAU 370 Direct-REAding Field SuRvey Results COMPARED to RIDP DAta Using BECK

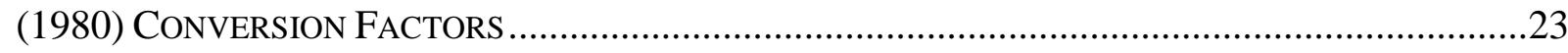

Figure 13.1994 AERIAL Survey Results Compared to RIDP DATA Using BeCK (1980) Conversion

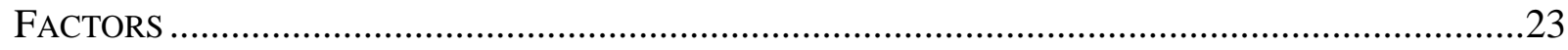

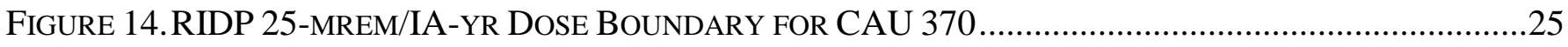

FigURE 15.EXAMPLE OF ESTIMATED 25-MREM/IA-YR DOSE RATE BOUNDARIES ....................................27

FigURE 16. UsING HiSTORICAL DATA TO OptIMIZE CHARACTERIZATION ..............................................27

\section{LIST OF TABLES}

TABlE 1. RIDP SENSITIVITY FOR INTERnAL Dose RATE CALCULATIONS ............................................8

TABle 2. S Summary COMPARISON OF EXTERnAL DOSE RATE RESUlTS...............................................18 


\section{ACRONYMS AND ABBREVIATIONS}

\begin{tabular}{|c|c|}
\hline $\mathrm{Am}$ & americium \\
\hline CAI & corrective action investigation \\
\hline CAS & Corrective Action Site \\
\hline CAU & Corrective Action Unit \\
\hline $\mathrm{cm}$ & centimeter(s) \\
\hline Co & cobalt \\
\hline Cs & cesium \\
\hline DCG & Derived Concentration Guide \\
\hline DOE & U.S. Department of Energy \\
\hline DQO & Data Quality Objective \\
\hline DRI & Desert Research Institute \\
\hline EG\&G & Edgerton, Germeshausen, and Grier Energy Measurements, Inc. \\
\hline EPA & U.S. Environmental Protection Agency \\
\hline $\mathrm{Eu}$ & europium \\
\hline FFACO & Federal Facility Agreement and Consent Order \\
\hline FGR & Federal Guidance Report \\
\hline $\mathrm{g} / \mathrm{m}^{3}$ & gram(s) per cubic meter \\
\hline Ge & germanium \\
\hline GIS & Geographic Information System \\
\hline IRL & Inverse Relaxation Length \\
\hline LANL & Los Alamos National Laboratory \\
\hline LLNL & Lawrence Livermore National Laboratory \\
\hline $\mathrm{m}$ & meter(s) \\
\hline microR/hr & microRoentgen(s) per hour \\
\hline mrem/IA-yr & millirem(s) per industrial access year \\
\hline NAEG & Nevada Applied Ecology Group \\
\hline $\mathrm{nCi} / \mathrm{m}^{2}$ & nanocurie(s) per square meter \\
\hline NDEP & Nevada Division of Environmental Protection \\
\hline NSTec & National Security Technologies, LLC \\
\hline NTS & Nevada Test Site \\
\hline PARCC & precision, accuracy, representativeness, completeness, and comparability \\
\hline
\end{tabular}




\section{ACRONYMS AND ABBREVIATIONS, CONTINUED}

$\mathrm{pCi} / \mathrm{g} \quad$ picocurie(s) per gram

PIC pressurized ionization chamber

$\mathrm{Pu} \quad$ plutonium

QA quality assurance

QC quality control

REECo Reynolds Engineering and Electrical Co.

RESRAD Residual Radioactivity

RIDP Radionuclide Inventory and Distribution Program

SAFER Streamlined Approach for Environmental Restoration

Sr $\quad$ strontium

TEDE total effective dose equivalent

Th thorium

TLD thermoluminescent dosimeter

U uranium

UNSCEAR United Nations Scientific Committee on the Effects of Atomic Radiation

WCP Waste Consolidation Project 


\section{EXECUTIVE SUMMARY}

Testing of nuclear explosives caused widespread contamination of surface soils on the Nevada Test Site (NTS). Atmospheric tests produced the majority of this contamination. The Radionuclide Inventory and Distribution Program (RIDP) was developed to determine distribution and total inventory of radionuclides in surface soils at the NTS to evaluate areas that may present long-term health hazards. The RIDP achieved this objective with aerial radiological surveys, soil sample results, and in situ gamma spectroscopy.

This white paper presents the justification to support the use of RIDP data as a guide for future evaluation and to support closure of Soils Sub-Project sites under the purview of the Federal Facility Agreement and Consent Order. Use of the RIDP data as part of the Data Quality Objective process is expected to provide considerable cost savings and accelerate site closures. The following steps were completed:

- Summarize the RIDP data set and evaluate the quality of the data.

- $\quad$ Determine the current uses of the RIDP data and cautions associated with its use.

- Provide recommendations for enhancing data use through field verification or other methods.

The data quality is sufficient to utilize RIDP data during the planning process for site investigation and closure. Project planning activities may include estimating 25-millirem per industrial access year dose rate boundaries, optimizing characterization efforts, projecting final end states, and planning remedial actions. In addition, RIDP data may be used to identify specific radionuclide distributions, and augment other non-radionuclide dose rate data. Finally, the RIDP data can be used to estimate internal and external dose rates.

Additional, enhanced RIDP data use is possible. Recommendations include finalizing the existing database and making it accessible to the Soils Sub-Project working group, evaluating Corrective Action Unit (CAU) 371 and CAU 372 data against the RIDP data, evaluating the use of conservative correction factors in estimating internal dose rates for application at other Soils Sub-Project sites, evaluating the use of conservative correction factors in estimating external dose rates for application at other Soils Sub-Project sites, and evaluating CAUs for closure through the Streamlined Approach for Environmental Restoration process. 


\subsection{INTRODUCTION}

\subsection{Purpose and Objectives}

The purpose of this white paper is to provide justification to support the use of the Radionuclide Inventory and Distribution Program (RIDP) data as a guide for future evaluation and to support closure of Soils Sub-Project sites under the purview of the Federal Facility Agreement and Consent Order (FFACO). Use of the RIDP data as part of the Data Quality Objective (DQO) process is expected to provide considerable cost savings and accelerate site closures. To determine if RIDP data are usable, the following steps were completed:

- Summarize the RIDP data set and evaluate the quality of the data.

- Determine the current uses of the RIDP data and cautions associated with its use.

- Provide recommendations for enhancing data use through field verification or other methods.

\subsection{Scope}

The scope of this white paper is to validate the RIDP data set in order to justify its use to support future closure of Soils Sub-Project sites under the FFACO. To accomplish this scope, a description and analysis of data collection methods and techniques, data storage systems, data quality evaluations and verification activities, cautions associated with the data, and guidelines for current data use are provided. This paper also provides recommendations for additional verification methods.

\subsection{Contents}

This white paper is divided into the following sections:

Section 1.0 Introduction - provides the purpose, scope, and contents of this white paper.

Section 2.0 Background - summarizes the purpose, objectives, and history of the RIDP, and describes the RIDP database.

Section 3.0 Data Summary - describes the data sources, including aerial radiological surveys, soil samples, and in situ measurements, used to develop the final RIDP values.

Section 4.0 Data Assessment - presents the results of data quality analyses, including pilot studies, calibration analysis, evaluation of detection capabilities and duplicate values, quality control (QC) procedures, and laboratory quality assurance (QA).

Section 5.0 Data Cautions and Use - provides a list of the cautions associated with the RIDP data if further verification is not completed and a set of guidelines for appropriate use of the data given the current level of QA.

Section 6.0 Conclusions and Recommendations - states why the RIDP data can be used for future closure of Soils Sub-Project sites and provides recommendations for possible additional verification methods.

Section 7.0 References - provides a list of references cited in this white paper.

Appendix A RIDP Data Conversion Process - outlines the method used to convert the RIDP data to units of picocuries per gram (pCi/g). 


\subsection{BACKGROUND}

\subsection{RIDP Purpose and Objectives}

The RIDP was developed to determine distribution and total inventory of radionuclides in surface soils associated with testing at the Nevada Test Site (NTS). Its objective was to evaluate areas of the NTS that may have been sufficiently contaminated to present long-term health hazards. The RIDP achieved this objective by using aerial radiological surveys, soil sample results, and in situ gamma spectroscopy.

\subsection{History of the RIDP}

Testing of nuclear explosives caused widespread contamination of surface soils on the NTS. Atmospheric tests produced the majority of this contamination. The RIDP conducted a thorough investigation of contaminated surface soils at the NTS using an in situ gamma spectroscopy technique developed in the 1970s by Lawrence Livermore National Laboratory (LLNL). The project began in 1981, and the final measurements were collected in 1986. A total of 3,850 measurements were collected from all areas of the NTS where aboveground tests had been conducted and where other localized sources of contamination may have been present, such as waste dumps. Areas not investigated included rugged highland areas and craters where the RIDP vehicle could not safely access the sites.

Aerial radiological survey data collected between 1976 and 1984 were used to plan locations for the in situ measurements. In addition, soil samples were collected to calibrate the in situ measurement system by establishing the radionuclide contaminant distribution with depth. Results of soil samples also provided ratios of non-gamma emitters to gamma emitters.

Edgerton, Germeshausen, and Grier Energy Measurements, Inc. (EG\&G) and the Desert Research Institute (DRI) performed five years of field work and three years of analysis. Data collection and analysis were carried out under the Basic Environmental Compliance and Monitoring Program of the U.S. Department of Energy (DOE). The results were published in five reports (McArthur and Kordas, 1983; 1985; McArthur and Mead, 1987; 1988; 1989). A summary report was also published (McArthur, 1991) that provided estimated levels of soil radioactivity at the NTS, including quantities of the 16 most significant man-made radionuclides produced by nuclear weapons testing.

\subsection{RIDP Database}

The RIDP in situ gamma spectroscopy data were originally archived. DRI imported the archived data into a Microsoft Access database in 2006 (Gray et al., 2007). RIDP values for man-made radionuclides were reported in nanocuries per square meter $\left(\mathrm{nCi} / \mathrm{m}^{2}\right)$, while naturally occurring radionuclides (e.g., potassium-40, thorium [Th]-232, uranium [U]-238) were reported in units of pCi/g.

National Security Technologies, LLC (NSTec), created a Microsoft Access database to support additional analyses and assessments, enhanced data development, calculations of 25-millirem per industrial access year (mrem/IA-yr) dose rate boundaries, and spatial Geographic Information System (GIS) analysis. The RIDP locations were grouped using GIS selection tools. The hard copy reports were reviewed to ensure that correct ratios and Inverse Relaxation Lengths (IRLs) were applied to each measurement for point-by-point analyses. Subsequently, aerial radiological survey results, dose-based limits, soil sample results, Corrective Action Unit (CAU) 370 data, and recent LLNL data were added to the database for data comparisons. The recent LLNL data had been collected to verify a modeling code to predict radioactive fallout from nuclear weapons detonations. The LLNL data provided limited opportunities for detailed comparisons but supported the RIDP and recent aerial radiological survey results for CAU 371. 


\subsection{DATA SuMMARY}

The following data sources were used to develop the RIDP data set:

- Aerial radiological surveys - The results of these surveys were used to select locations for in situ field measurements.

- Soil samples - Results were used to determine depth distribution of various radionuclides in soil for calibration of the in situ measurement system. In addition, radiochemical analysis of soil samples provided information about radionuclides that do not emit gamma rays and therefore cannot be measured by in situ spectroscopy.

- In situ measurements - Field measurements of external exposure rate and radionuclide activities were collected by in situ gamma spectroscopy.

\subsection{Aerial Radiological Surveys}

Aerial radiological surveys were performed from a helicopter to improve upon previous surveys that had been conducted using fixed wing aircraft and to more clearly define contaminant boundaries and relative levels of contamination on the NTS. The aerial surveys provided greater accessibility to contaminated areas, increased measurement sensitivity, and improved spatial resolution. The RIDP used the results of these surveys to develop a statistically based sampling plan for in situ measurements.

The aerial surveys were used to bias sample locations to areas with higher contamination. In general, the RIDP collected more in situ measurements on a tighter grid in areas that had been shown by the aerial surveys to have higher contamination. In areas further away from a ground zero and that were shown by the aerial surveys to have lower contamination levels, fewer in situ measurements were collected with larger grid spacing.

\subsection{Soil Samples}

At most of the sites investigated by the RIDP, radionuclides are concentrated in the top several centimeters $(\mathrm{cm})$ of soil. However, at some locations, activation products, such as europium (Eu), extend deeper than fission products (e.g., cobalt [Co] and cesium [Cs]). Determination of the contaminant distribution with depth is necessary for in situ measurement system calibration.

The RIDP collected soil samples at selected locations for analysis by gamma spectroscopy. Samples were collected in increments of $0-2.5 \mathrm{~cm}, 2.5-5 \mathrm{~cm}, 5-10 \mathrm{~cm}$, and 10-15 cm. At selected sites, such as SEDAN, where it was suspected that radioactivity extended deeper into the soil, samples were collected in six increments to a depth of $30 \mathrm{~cm}$. Soil samples were usually collected in areas where in situ measurements were taken and along perpendicular transects through a ground zero.

The activity of each radionuclide was determined to decrease exponentially with depth, with the rate of decrease characterized by an IRL $(\alpha)$ expressed in units of $\mathrm{cm}^{-1}$. The method for calculating IRLs from soil sample results varied during the project but generally relied on the following equation:

$$
S_{z^{\prime}}=S_{o} e^{-\left(\alpha z^{\prime}\right)}
$$

Where:

$S_{0}$ is the activity per $\mathrm{cm}^{3}$ at the soil surface

$\alpha$ is the IRL in $\mathrm{cm}^{-1}$

$\mathrm{z}^{\prime}$ is the contaminant depth 
Average calculated IRLs for each radionuclide were used for analysis of the in situ measurements. In some instances, depth distributions near a ground zero were different from those farther away. The measurements from the ground zero regions were therefore analyzed using a different set of IRLs.

Soil samples from the top increment at each location were also radiochemically analyzed for strontium (Sr)-90, plutonium (Pu)-238, Pu-239/240, Cs-137, and americium (Am)-241. The ratios of Sr-90 to Cs-137, Pu-238 to Am-241, and Pu-239/240 to Am-241 were then calculated and applied to the RIDP measurements for the associated gamma-emitting radionuclides. The RIDP reports and the DRI database used these values to calculate total inventory for these radionuclides.

The analyses in this white paper required that the correct ratio and IRL be applied to each RIDP measurement. This was accomplished through a review of the hard copy reports and GIS tools. The ratio and IRL for each RIDP measurement were developed for this white paper and included in the enhanced Microsoft Access database described in Section 2.3 to convert RIDP data to units of pCi/g as outlined in Appendix A. An internal QA of this process was completed; however, a more formal QA should be performed prior to release of the enhanced database to the Soils Sub-Project working group.

The IRLs were also required to assess external dose rates. External dose rates were calculated using coefficients provided by Beck (1980). Beck’s coefficients were developed for surface deposition of radionuclides resulting from aboveground nuclear weapons testing. Nuclear weapons test sites are unique because the contamination is distributed exponentially with depth. In addition, the depth distribution is different for different radionuclides and at different locations. Beck's coefficients allow the most applicable conversion factors for each RIDP measurement. Other dose rate assessment codes, such as the Residual Radioactivity (RESRAD) model, do not take into account the exponential distribution with depth known to exist at the NTS. A number of analyses in this white paper use the Beck coefficients to assess external dose rates at RIDP locations by calculating the exposure for each radionuclide, summing those exposures, and converting to effective dose equivalent rates.

\subsection{In Situ Measurements}

In situ measurements were collected with a collimated high-purity germanium (Ge) detector mounted on an off-road vehicle and suspended approximately 7.4 meters (m) above the ground (Figure 1). The detector had a circular field of view with a radius, or sample size, of approximately $10 \mathrm{~m}$ for Am-241, $12 \mathrm{~m}$ for Cs-137, and $21 \mathrm{~m}$ for Co-60. Other components of the measurement system, including an amplifier, power supply, pulse-height analyzer, and desktop computer, were located inside the vehicle. The vehicle was positioned near a measurement point, and the detector was cantilevered out over the measurement location. The operator entered a description of the location into the computer and began the spectrum acquisition. During the 15-minute acquisition period, a pressurized ionization chamber (PIC) set at $1 \mathrm{~m}$ above the ground under the detector measured the external exposure rate. At the end of the acquisition period, the detector was retracted, and the vehicle was moved to the next location.

The system was maintained and operated by EG\&G. During each measurement, pulses from gamma rays reaching the detector were sorted into a 4,096-channel energy spectrum. At the end of the 15-minute count period, the spectra were transferred to the computer, where a spectral analysis program computed the concentrations of various radionuclides. Finally, the spectra were transferred to magnetic tape for further future analysis. As each measurement was completed, the spectra were sent to LLNL for analysis by a modified version of GAMANAL (Gunnink and Niday, 1971), a more sophisticated spectral analysis program than the one used in the field. 


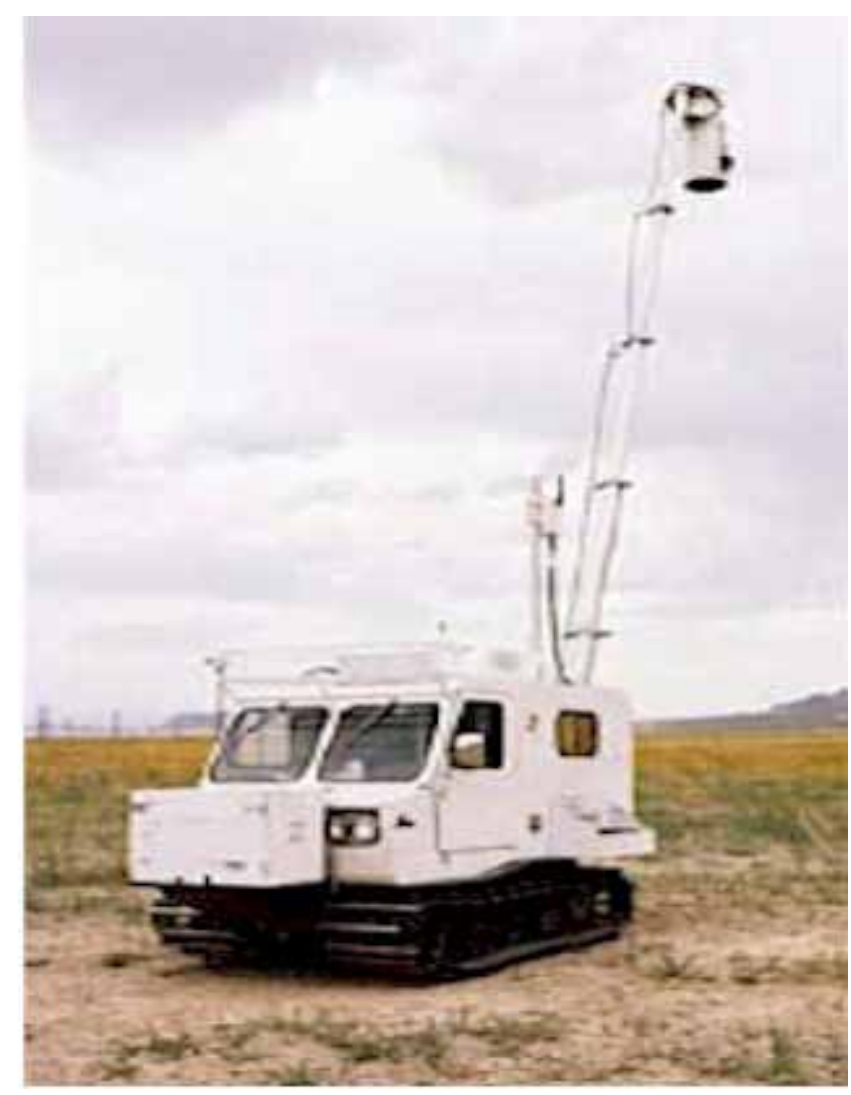

Figure 1. Vehicle USED To Collect In Situ MeAsurements

\subsection{Data Assessment}

Precision, accuracy, representativeness, completeness, and comparability (PARCC) are used to evaluate data quality. These PARCC criteria had not been developed at the time of the RIDP; however, the concepts behind the PARCC criteria can be used to assess the RIDP data by using the data quality information collected at the time. The discussions in the following sections indicate how the PARCC parameters were evaluated.

Prior to field activities, an extensive series of calibrations and test measurements were performed on the detectors to ensure accuracy. In addition, the energy calibration of each detector was checked three times per day during field operations. Consistency of these measurements ensured precision over time. Approximately 30 percent of the 8,550 spectra recorded during the RIDP were laboratory calibration runs to verify the angular response and effective area of the detector. Another 23 percent of the spectra were field calibrations.

Laboratory QA procedures during the RIDP included inter-laboratory comparisons (comparability), analysis of blind reference samples (accuracy), and comparisons of hidden replicates (precision). A QA "referee" managed sampling protocols, reviewed data results, and provided summary statements of data quality. In addition, LLNL conducted an assessment of pilot measurements collected prior to 1980. Finally, for this white paper, NSTec has evaluated other data sets and compared them to the RIDP data to further assess the RIDP data quality. These results are presented in Section 4.7. 


\subsection{Pilot Measurements and Project Improvements}

Pilot studies for the RIDP were conducted prior to 1980. Difficulties were encountered with instrument calibration and storage. LLNL was asked to perform the following tasks for DOE to expand the program:

- Perform an assessment of the methodology and results.

- Perform an engineering evaluation of the equipment.

- Provide recommendations for improvement.

A summary of previous data, including Field Instrument for Detection of Low-Energy Radiation data and soil sample results, was developed by the Nevada Applied Ecology Group (NAEG) and stated that soil sample results prior to 1980 were questionable due to laboratory analytical problems (Anspaugh and Kordas, 1980).

In addition, obtaining a representative set of soil samples to accurately reflect site conditions and the associated potential dose rate is difficult. Estimating the total effective dose equivalent (TEDE) from soil samples is problematic due to the heterogeneous nature of soil contamination. This is known as the "hot particle problem." The hot particle problem leads to incorrect dose rate estimates depending on whether or not a "hot particle" is captured in the sample or sample aliquot. The distribution of Pu isotopes in soil has been found to vary by a factor of 10 between individual 1-gram aliquots from a single soil sample (Los Alamos Scientific Laboratory, 1971). In situ methods are not subject to these errors because the sample size, or the measurement field of view, is large relative to an individual soil sample. The large field of view integrates contributions from discrete particles and trinity glass, and represents a more realistic exposure scenario than soil samples.

In 1976, EG\&G built the vehicle and supporting equipment for taking in situ measurements at the NTS. However, EG\&G chose not to operate the system. DRI took over the system, extensively modified the electrical components, and began taking measurements in 1978 on Frenchman and Yucca Flats. However, these measurements were of unknown validity or were unreported. DRI then collected measurements around the perimeter of the NTS until the project was halted in 1980.

LLNL reported that until 1980, very little of the data collected by NAEG and DRI was reliable. The scope of the project was unclear, no schedule had been developed for the project, and criteria such as what should be measured and to what accuracy, as well as basic reporting standards, were poorly defined and changed frequently. Additional problems with calibration procedures, spectral analysis software, and equipment configuration were noted. Protocols to address these issues were integrated into the RIDP.

To continue the project, LLNL endorsed the use of the in situ measurement method, supplemented by judicious soil sampling to determine ratios of radionuclides and depth distributions for calibration of the in situ detectors. It was recommended that aerial radiological surveys be used to guide the more detailed, ground-based measurements.

The RIDP also integrated lessons learned from soil sampling conducted at the NTS and Tonopah Test Range, closure work performed at Eniwetok Atoll, and activities conducted by NAEG. 


\subsection{Calibration Analysis}

Details regarding calibration of the in situ detector are provided by Anspaugh (1976), Beck et al. (1972), and Tipton et al. (1978). The equation used to convert counts in a given energy range to specific radionuclide activities in units of $\mathrm{nCi} / \mathrm{m}^{2}$ requires several parameters, including detector response at various energies, detector response with respect to the angle of gamma rays interacting with the detector, gamma ray attenuations in air and soil, soil density and moisture content, and radionuclide depth distribution.

Detector response was determined empirically using calibrated sources. The consistency of detector response was checked three times per day during field operations. Mass attenuation coefficients for the energies of interest were obtained by interpolation of values given by Beck et al. (1972). IRLs of various radionuclides were derived from soil sample results. Contaminant distribution with depth is a sensitive parameter, and the RIDP made efforts to select this parameter to minimize errors. The following parameters values were assumed:

- Air density: 0.001204 grams per cubic centimeter $\left(\mathrm{g} / \mathrm{cm}^{3}\right)$

- Wet soil density: $1.5 \mathrm{~g} / \mathrm{cm}^{3}$

- Soil moisture: 10 percent

McArthur and Kordas (1983) evaluated the effect of soil moisture content and density values on calculations and found that, for Am-241, a 20-percent difference in actual soil moisture from assumed soil moisture results in a 3-percent error, and the small error leads to conservative results when the actual value is lower than the assumed value. This error is smaller for other radionuclides. Additional studies documented in DOE's Environmental Measurements Laboratory Procedures Manual, HASL-300, indicate the insensitivity of these parameters (Helfer and Miller, 1988).

Since the RIDP derived sensitive parameters, such as IRL, through empirical methods and used assumed values only for relatively insensitive parameters, RIDP measurement errors were minimized. The IRL is a measure of how uniformly the contaminant is distributed with depth; therefore, this is a sensitive parameter for both RIDP and direct soil sampling methods. The RIDP found these distributions varied by radionuclide and location. A static soil sample depth will concentrate some values and dilute others. This is a potential source of error for both RIDP and soil sample data and thus a potential basis for non-comparable data.

\subsection{Detection Capability Evaluation}

Detection capabilities for individual measurements were not reported in the RIDP database. To be of value, the RIDP system must be sensitive enough to detect contaminants at or below decision levels. The detection capabilities of the RIDP measurements were estimated for this white paper using a reporting protocol observed in the RIDP reports that identified measurements that were at or near detection capabilities as "upper-limit values.” The results of a query against this reporting protocol were verified against maps presented in the RIDP reports, and an average upper-limit value was established for each radionuclide. Table 1 provides the maximum upper-limit value for each radionuclide and compares them to the draft Derived Concentration Guides (DCGs) established for internal dose rates at CAU 370. By summing the maximum upper limit-values for all radionuclides, a total dose rate of $0.02 \mathrm{mrem} / \mathrm{IA}-\mathrm{yr}$ is found, which is less than 0.1 percent of the 25-mrem/IA-yr limit. As a result, it can be stated that the RIDP system can detect radionuclides to determine internal dose rates below decision levels. 
TABLE 1. RIDP SENSITIVITY FOR INTERNAL DOSE RATE CALCULATIONS

\begin{tabular}{|c|c|c|c||}
\hline RADIONUCLIDE & $\begin{array}{c}\text { DERIVED } \\
\text { CoNCENTRATION } \\
\text { GUIDE (pCi/g) }\end{array}$ & $\begin{array}{c}\text { MAXIMUM } \\
\text { UPPER-LIMIT } \\
\text { VALUE (pCi/g) }\end{array}$ & $\begin{array}{c}\text { DOSE RATE } \\
\text { (mrem/IA-yr) }\end{array}$ \\
\hline Am-241 & $5.63 \mathrm{E}+03$ & 5.15 & $9.14 \mathrm{E}-04$ \\
\hline Co-60 & $2.70 \mathrm{E}+06$ & 1.03 & $3.82 \mathrm{E}-07$ \\
\hline Cs-137 & $1.63 \mathrm{E}+06$ & 1.36 & $8.35 \mathrm{E}-07$ \\
\hline Eu-152 & $6.99 \mathrm{E}+06$ & 3.62 & $5.18 \mathrm{E}-07$ \\
\hline Eu-154 & $5.09 \mathrm{E}+06$ & 6.16 & $1.21 \mathrm{E}-06$ \\
\hline Eu-155 & $3.42 \mathrm{E}+07$ & 5.43 & $1.59 \mathrm{E}-07$ \\
\hline Pu-238 & $6.30 \mathrm{E}+03$ & 6.70 & $1.06 \mathrm{E}-03$ \\
\hline Pu-239 & $5.72 \mathrm{E}+03$ & 99.10 & $1.73 \mathrm{E}-02$ \\
\hline Sr-90 & $4.52 \mathrm{E}+05$ & 3.49 & $7.73 \mathrm{E}-06$ \\
\hline Th-232 & $1.86 \mathrm{E}+03$ & 2.31 & $1.24 \mathrm{E}-03$ \\
\hline U-235 & $2.45 \mathrm{E}+04$ & 2.89 & $1.18 \mathrm{E}-04$ \\
\hline U-238 & $2.55 \mathrm{E}+04$ & 11.33 & $4.44 \mathrm{E}-04$ \\
\hline \hline
\end{tabular}

As with other methods used to measure radioactivity, RIDP detection capability is related to background radiation in a given area. It is an indication of how well an instrument can discern contamination from background radiation. Generally, the higher the local background radiation levels, the higher the detection capability of a given instrument.

Detection capabilities of the RIDP measurements for external dose rates were determined by calculating the average and the standard deviation of the upper-limit values for Co-60, Cs-137, Eu-152, and Eu-154. Average external dose rates plus two standard deviations were then calculated for each radionuclide. These isotope-specific external dose rates were summed to determine a conservative sensitivity estimate. This determination indicates that the RIDP measurement sensitivity for external dose rate is approximately 4 mrem/IA-yr. This was calculated from non-decay-corrected values. Over time, the value will decrease and, essentially, the RIDP data will become more sensitive.

The RIDP sensitivity estimate for determining external dose rates was compared with estimated thermoluminescent dosimeter (TLD) sensitivity. TLD sensitivity was estimated using results of TLD stations across the NTS. This is analogous to the RIDP estimate because the RIDP upper-limit values were also derived across the NTS, where background radiation varies. An average background TLD external dose rate plus two standard deviations was calculated. This resulted in an estimated TLD measurement sensitivity for external dose rate of approximately $16 \mathrm{mrem} / \mathrm{IA}-\mathrm{yr}$, which is much closer to the 25-mrem/IA-yr limit than the RIDP sensitivity estimate. Both the RIDP estimate and the TLD estimate are at a 95-percent confidence interval. In most areas, the actual values are lower than the estimate. This evaluation reflects on the accuracy, precision, and relative sensitivity of the RIDP data. 


\subsection{Duplicate Measurement Quality}

McArthur and Kordas (1983) reported QA results for duplicate measurements. The average deviation from the mean of duplicate sets was 8.6 percent. Maximum deviations were not presented. For this white paper, NSTec also performed an assessment of the RIDP data to determine duplicate measurement quality. A total of 454 duplicate RIDP measurements were assessed. Only 35 of the duplicate measurements varied from each other by more than 25 percent. All of the less precise values were at or near the calculated detection capability; therefore, as shown in Section 4.3, any errors at these levels have an insignificant impact on RIDP-calculated dose rates. The analysis of duplicate measurements indicates that higher values result in better agreement between values. This indicates that at levels that could impact total dose rate calculations, the RIDP data are precise.

\subsection{Quality Control Measurement Analysis}

The RIDP collected measurements in real time to evaluate data quality. These measurements were collected with PICs set $1 \mathrm{~m}$ above the ground. The PICs directly measured the external exposure rate in microroentgens per hour (microR/hr). The RIDP also measured radionuclide-specific contaminant levels and used these measurements to calculate an expected exposure rate in real time. During data acquisition, the expected exposure rate that was calculated from the in situ measurements was compared to the PIC measurements. If the RIDP measurements led to an expected exposure rate that was different from the PIC-measured exposure rate, which indicated a potential measurement problem, another measurement was taken, and, if needed, the instrument was recalibrated. While somewhat informal and based on judgment, this process improved RIDP measurement accuracy.

\subsection{Laboratory Quality Assurance}

Reynolds Engineering and Electrical Co. (REECo) analyzed soil samples during the RIDP. Each RIDP report, except the first, contains an appendix that addresses QA issues for soil samples, and describes any changes in procedure since the previous report. Each appendix explains problems with the data sets and how they were addressed, and concludes with a summary statement. Each appendix also presents replicate, inter-laboratory, and other supporting QA data.

The QA procedures in each report included the following elements:

- Analysis of replicate aliquots from samples, a measure of data precision

- Analysis of independently calibrated reference blinds for a related program, a measure of data accuracy

- Duplicate gamma spectroscopy measurements of samples by LLNL, a measure of data comparability

In addition, to resolve uncertainties and provide further assurance of data reliability and comparability, samples were typically analyzed by two independent labs, for a total of four labs.

The sections below summarize specific data quality findings and limitations in each RIDP report. While the raw laboratory QA data are not readily available, the summary discussions provided in the RIDP reports are adequate to determine data quality and usability for the limited purposes of estimating IRLs and ratios. The analyses indicate there are no specific problems with the data that would preclude further development of the RIDP data or the evaluation of RIDP data quality. RIDP soil sample results will not be used directly in the DQO process or for future project planning activities. 


\subsubsection{McArthur and Kordas, 1985 (RIDP Report \#2)}

Inconsistencies were noted in REECo soil sample results. Possible causes included the "hot particle problem," errors in technique, and errors in data transcription or sample labeling. There was "reasonably good agreement” among the four analytical labs, except for samples with low analytical results. For samples treated by chemical separation, inconsistencies were attributed to the hot particle problem and small final aliquots, which were the result of efforts to keep activity levels in the laboratory low.

The authors concluded that the REECo data were satisfactory for RIDP purposes because RIDP used averages of many measurements and because the program objectives specified a final inventory determination within a factor of two. However, they recommended that a "more extensive and formalized QA program is desirable,” and referred to a new QA program to develop for future use.

\subsubsection{McArthur and Mead, 1987 (RIDP Report \#3)}

The QA program for this series of analyses included the same elements as the previous program (including analysis by four labs, two of them independent) with the addition of blind and background samples and hidden replicates. In addition, a "referee” was provided by Los Alamos National Laboratory (LANL) and assigned to manage blind and replicate samples so that they remained unknown to the analyst. The referee also kept a log of sample numbers. REECo included additional internal performance tests using actual samples.

The referee evaluated sample results and flagged questionable data for further investigation. The flagged data were first reviewed for transcription and typographical errors. The hot particle problem was then investigated.

The results of the QA evaluation indicated that there was good reproducibility based on blind sample results. The replicate sample results were considered acceptable. Exceptions included a few samples with hot particles, two samples for which an explanation of the discrepancy was not determined, and an unexplained high bias for Am-241 results collected from SEDAN.

The authors concluded that the data set is a reliable and accurate representation of radioactivity in the samples tested.

\subsubsection{McArthur and Mead, 1988 (RIDP Report \#4)}

For this series, samples from SCHOONER were collected under a modified QA program (i.e., modified labeling procedures) to accommodate a new independent laboratory. Other elements remained the same, including inter-laboratory comparisons, analysis of blind reference samples, and comparisons of hidden replicate samples. A LANL referee managed blinds and replicates, and evaluated the test results.

The results of the QA evaluation using only SCHOONER samples (though they had low activity levels) indicated acceptable agreement for blind reference samples and replicate samples. For the entire data set, a few of the REECo results and one of the independent lab results were flagged as questionable but were not rejected. The data set as a whole was judged as reliable. The authors suggested that the flagged results should be used with care, and that the practice of averaging measurements reduces errors associated with individual analyses. 


\subsubsection{McArthur and Mead, 1989 (RIDP Report \#5)}

The QA program did not change for this series. Problems with some of the flagged sample results were attributed to the hot particle problem. Other causes were not determined but may be attributed to errors in transcription, labeling, computation, calibration, or contamination.

This series of analyses also included a comparison of results for fine and coarse soil fractions (previously, only fine soil fractions were analyzed). This comparison showed that, as previously assumed, most of the radioactivity is in the fine soil fractions. This is not site-dependent and is a consistent feature of radioactive contamination resulting from nuclear weapons testing.

Based on the analysis of blind and replicate samples, the overall data set was judged to be reliable. It was noted that flagged data should be used with caution.

\subsection{Comparisons to Other Data Sets}

To further assess RIDP data quality for this white paper, NSTec has compared the RIDP data to data collected by other methods. The results of these evaluations are presented below.

\subsubsection{Aerial Radiological Survey Data}

RIDP results for Am-241 and strong gamma-emitting contaminants of concern were compared to aerial radiological survey data collected in 1994 (Hendricks and Riedhauser, 1999). Am-241 aerial radiological survey data are presented in units of counts per second, and strong gamma-emitting radionuclides are quantified as estimated exposure rates. Aerial radiological survey data, by nature, represent average contaminant levels over wide areas.

The aerial radiological survey data are presented as ranges of results, or bins. There are six bins for Am-241 aerial radiological survey data and ten bins for total man-made aerial radiological survey data. The RIDP results were grouped according to the ranges or bins in which they were located. GIS selection tools were used to determine which RIDP values were geographically located within each bin. The RIDP values within each of the bins were averaged and compared to the middle value of each aerial radiological survey range.

Figures 2 and 3 illustrate these comparisons and demonstrate a linear relationship based on wide-area averages of RIDP data. The purpose of this evaluation was an initial indication of whether the RIDP data are of reasonable quality to undergo additional assessment and evaluation. The results indicate that the RIDP data are of reasonable quality to proceed with the additional quality assessments discussed later in this white paper.

The additional assessments presented in this white paper establish RIDP data quality more firmly than the initial positive indication provided by these wide-areas average comparisons. Additional data development may allow a coefficient to be applied to the aerial radiological survey data to estimate dose rates in areas where there is sparse RIDP measurement coverage. The result of such an estimate would only provide a wide-area average.

Since the actual variability of contaminants in soils is quite high, such a process would be developed with conservative assumptions. This limitation exists for application of a correction factor whether the factor is applied to RIDP data or to newly collected data. In either case, application of a correction factor to aerial radiological survey data to make closure decisions requires a full understanding of the actual variability of contaminant levels within a site-specific survey bin and, based on that variability, calculating an appropriately conservative correction factor to estimate dose rates. 


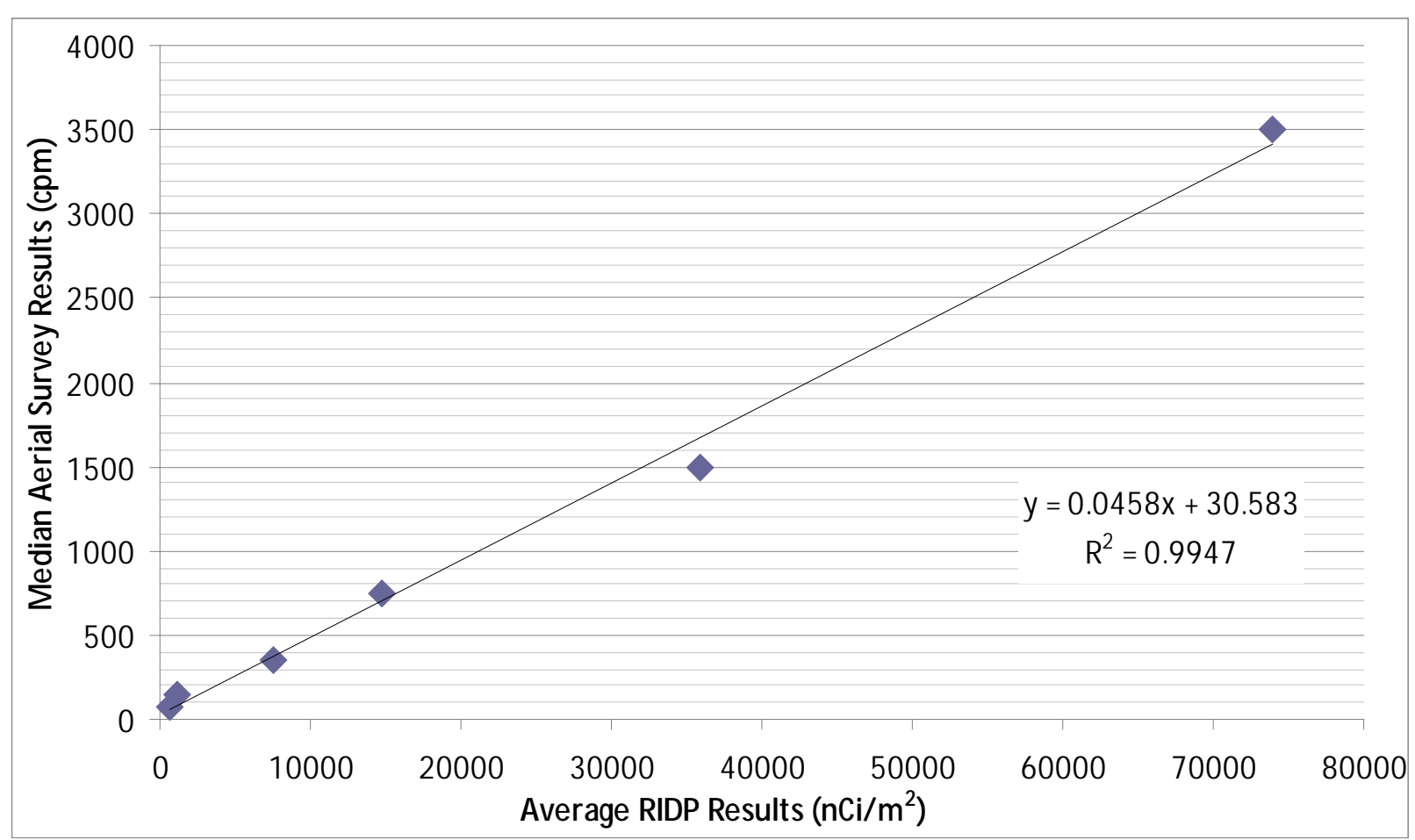

FiguRE 2. 1994 AERIAL RADIOLOGICAL SURVEY DATA COMPARED TO RIDP RESULTS FOR AM-241

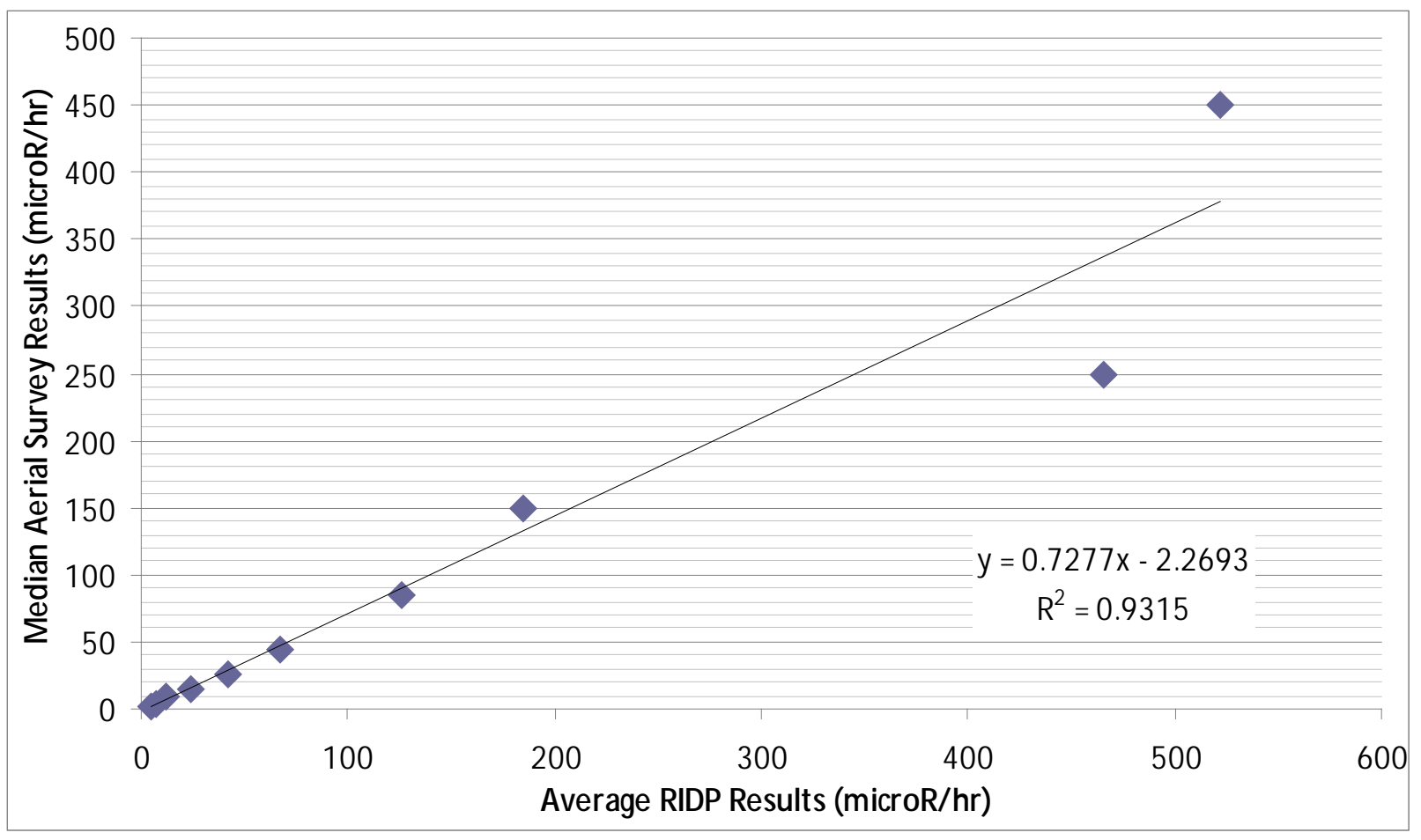

Figure 3. 1994 AERIAL RAdIOLOGICAL SURVEY DATA COMPARED TO RIDP RESULTS FOR TOTAL MAN-MADE RADIONUCLIDES 


\subsubsection{Corrective Action Unit 370 Investigation Results}

For this white paper, the RIDP data have been compared to the CAU 370 corrective action investigation (CAI) results, and the data show excellent agreement. Evidence demonstrating the currency and accuracy of the RIDP data are presented below.

Dose rate assessments for CAU 370 involved calculating internal and external dose rates separately; therefore, the following comparisons and discussion are also separated in this way.

\subsubsection{Corrective Action Unit 370 Internal Dose Rates}

Soil sample results for CAU 370 were used to assess internal dose rates. The RESRAD code models dose rates based on the concentrations of radionuclides in soil and was used to convert soil sample results in units of $\mathrm{pCi} / \mathrm{g}$ to dose rates in units of mrem/IA-yr. The RESRAD code was also used to determine draft DCGs for CAU 370.

To compare the RIDP results to the CAU 370 soil sample results for the primary, internal dose-driving radionuclides, the RIDP data have been converted to units of $\mathrm{pCi} / \mathrm{g}$ using the method in Appendix $\mathrm{A}$. Figures 4-6 compare the converted RIDP data to the CAU 370 soil sample results averaged across each CAU 370 soil sample plot for Am-241, Pu-238, and Pu-239.

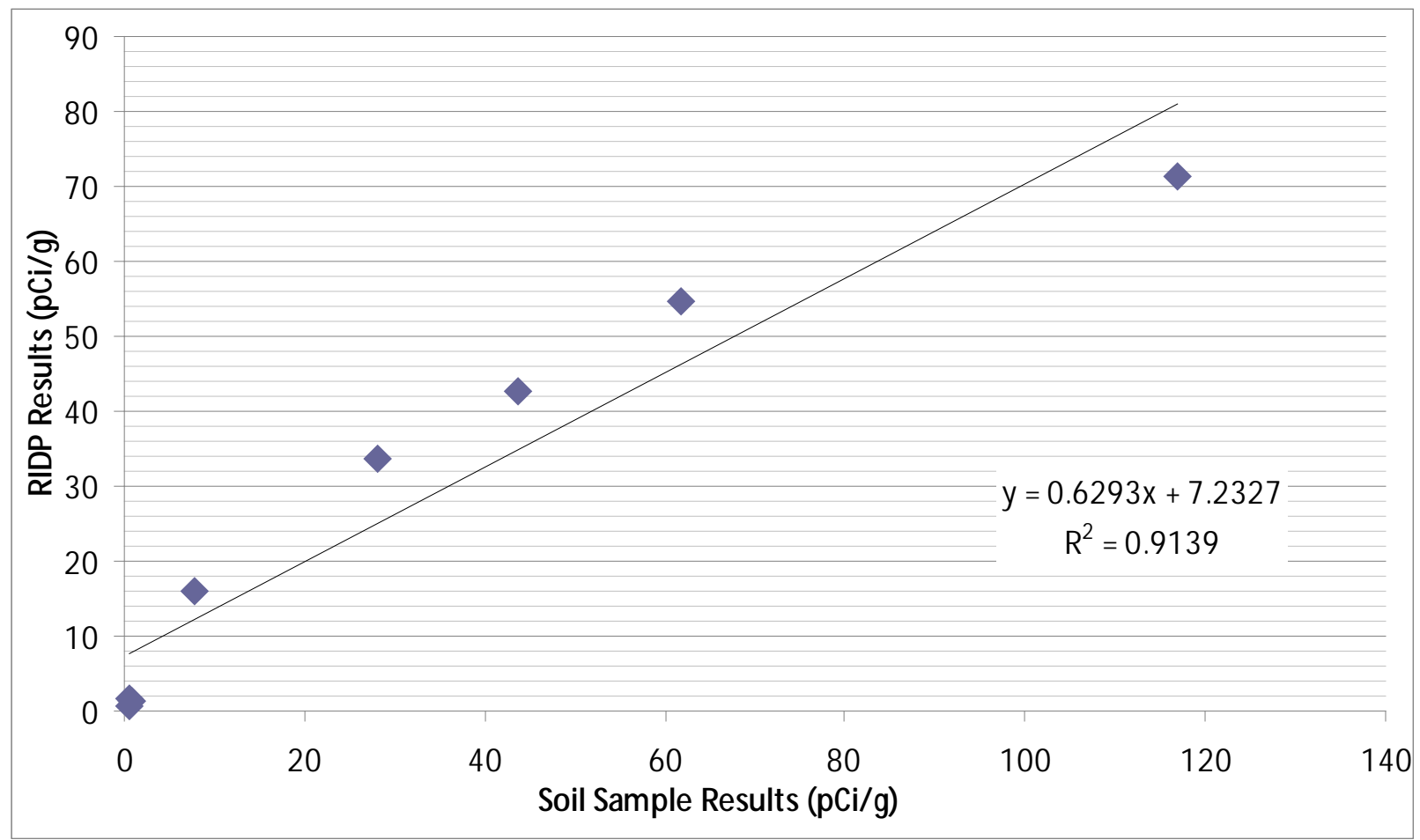

FigURE 4. CAU 370 CAI RESULTS FOR AM-241 COMPARED TO RIDP DATA 


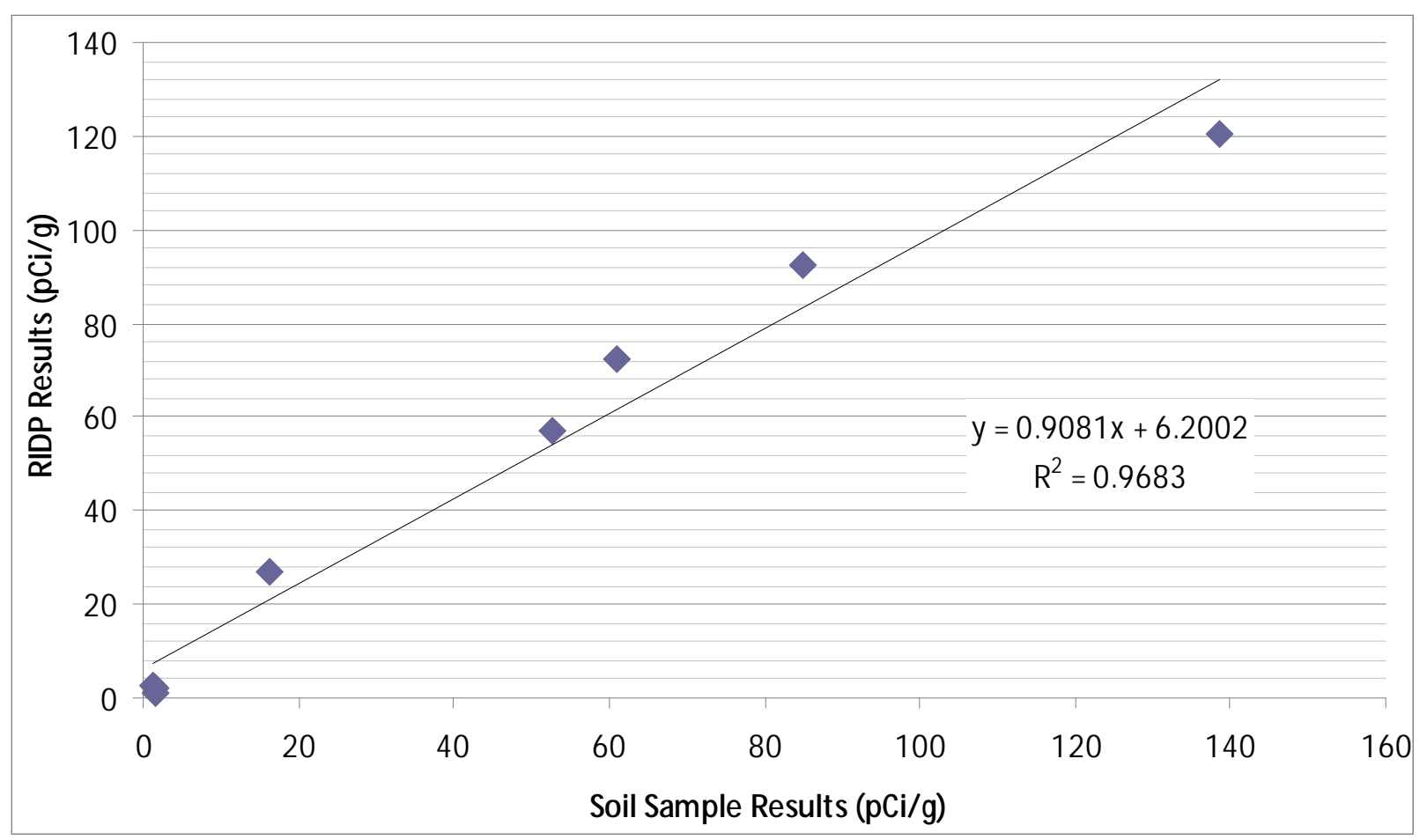

Figure 5. CAU 370 CAI Results For PU-238 CoMPAREd to RIDP DATA

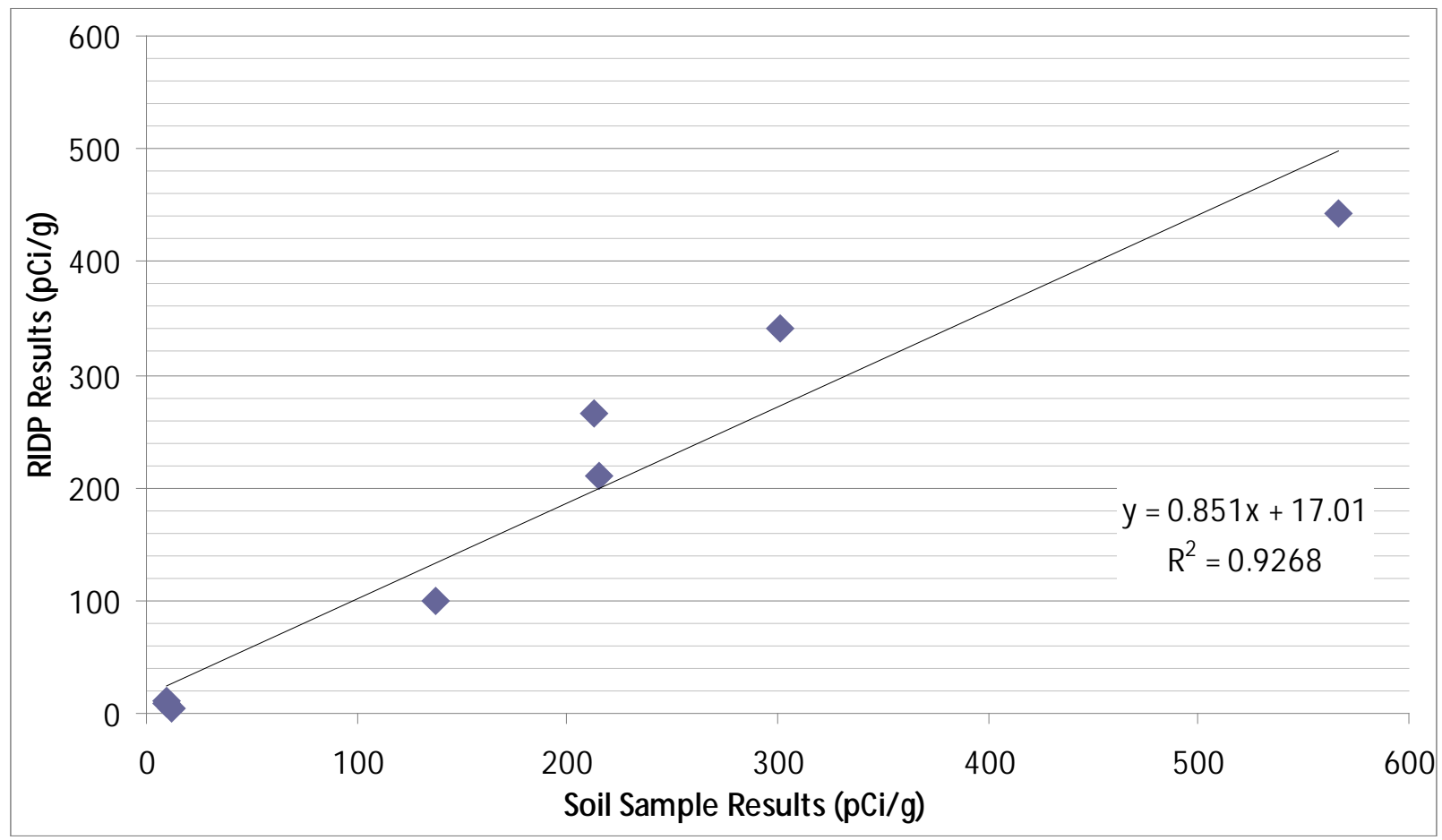

Figure 6. CAU 370 CAI RESUlts FOR PU-239 COMPARED TO RIDP DATA 
The graphs in Figures 4-6 show that the data are well correlated; however, converted RIDP measurements expressed in units of pCi/g vary from the average CAU 370 soil sample results at each sample plot. The difference between the converted RIDP values and the average CAU 370 soil sample values potentially results from the following sources:

1) RIDP Ratios: Soil samples collected during the RIDP provided ratios to determine contaminant values for radionuclides that the RIDP did not directly measure. Ratios were determined through a limited number of soil samples collected by the RIDP at subject locations. Ratios were then applied across each entire subject area. Applying ratios that were calculated using only a few soil samples to many RIDP measurements may result in some error.

2) IRLs: This parameter is based on contaminant distribution with depth. This distribution is known to vary by radionuclide and by location, especially near ground zero locations. IRLs were determined through a limited number of soil samples collected by the RIDP at subject locations. IRLs were then applied to RIDP measurements across each entire subject area. Applying IRLs that were calculated from only a few soil samples to many RIDP measurements may result in some error.

3) CAU 370 Plot Data: Relatively high variability may result when a sample mean is calculated from multiple soil samples, even when the samples are collected from locations close to each other. In addition, variability in contaminant distribution with depth may cause variability in sample results, even across a single sample plot. A uniform sampling depth of $5 \mathrm{~cm}$ may concentrate values at some locations and dilute values at others. This variability can produce the differences in results between the two characterization methods.

The magnitude of the differences between converted RIDP results and CAU 370 soil sample results caused by each potential source listed above cannot be easily quantified with existing data. The converted RIDP data involve potential error; however, average soil sample values also have associated error. To provide context to the differences between the two data sets, internal dose rates based on converted RIDP data and internal dose rates based on the average CAU 370 soil sample results plus or minus two standard deviations were compared and plotted in Figure 7. Internal dose rates were calculated for both data sets using the draft DCGs established for CAU 370. The error bars shown in Figure 7 are associated with the four CAU 370 sample results collected in each sample plot and were calculated at the 95-percent confidence level. 


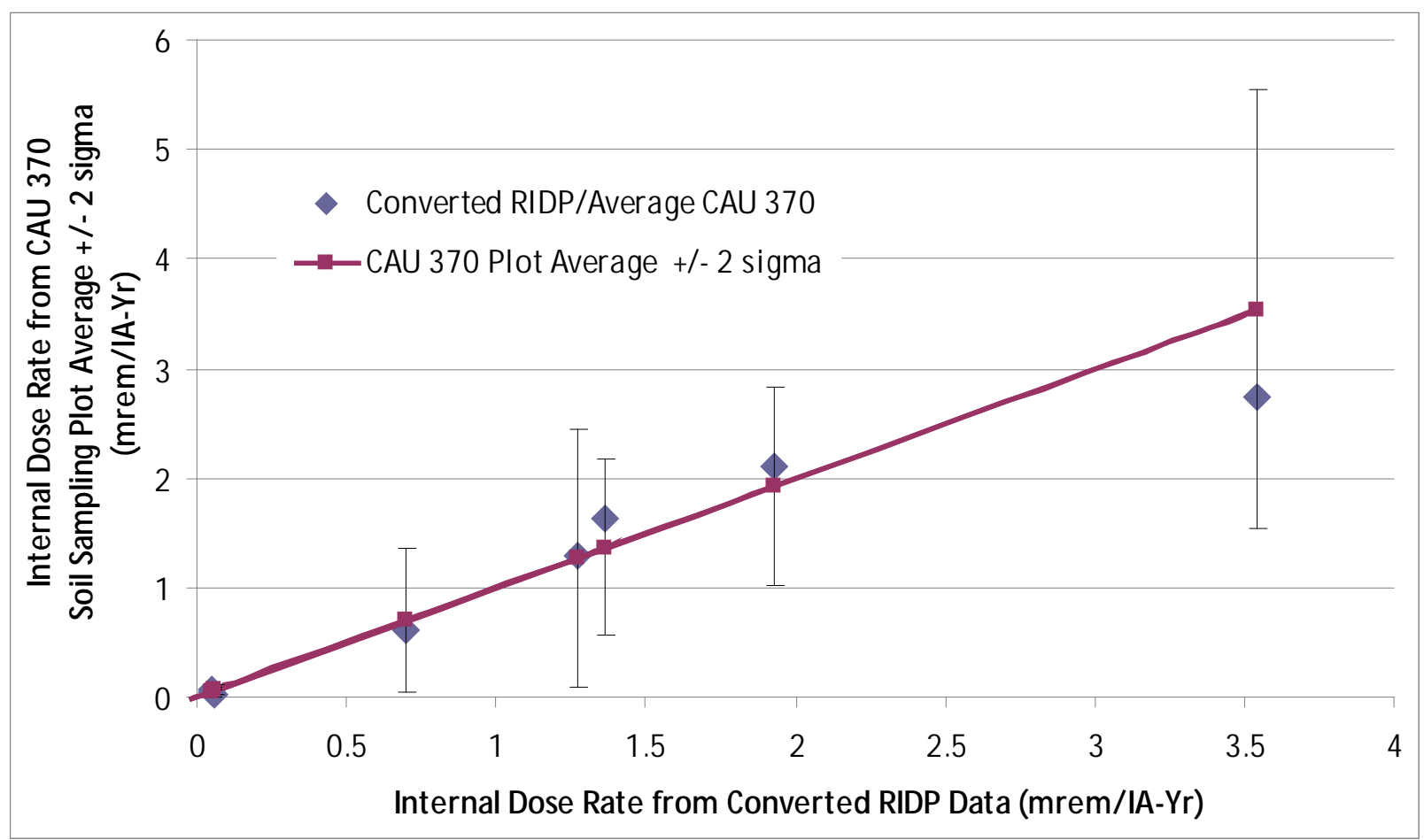

FIGURE 7. COMPARISON OF INTERNAL DOSE RATES

The maximum difference between internal dose rates calculated from RIDP values and from average CAU 370 soil sample results is $0.8 \mathrm{mrem} / \mathrm{IA}$-yr. The difference was calculated at the 95-percent confidence level based on two results. This difference is insignificant at the relatively low contaminant levels found at CAU 370 and is more than accounted for by the error associated with the average soil sample value itself.

The deviation (95-percent confidence level) of internal dose rate based on CAU 370 soil sample data alone was also calculated. A maximum deviation of 2 mrem/IA-yr occurred at sample plot M. While the uncertainty in the average internal dose rate based on CAU 370 soil sample data is higher than the difference between internal dose rates calculated from RIDP values and from average CAU 370 soil sample results, it cannot be concluded that RIDP provides a more precise measure of internal dose. It can only be concluded that using converted RIDP values to determine internal dose rates is as accurate as using the average CAU 370 soil sample values across the sample plots at CAU 370.

The term missing from this evaluation is a propagated RIDP error based on uncertainties in RIDP measurements, IRLs, and RIDP ratios. Calculating such an error is outside the scope of this white paper and may not be possible based on available data (i.e., historical RIDP data and CAU 370 data); however, as explained further in Section 5.2.2, such a calculation may not be needed to effectively use the RIDP data for guiding decision making.

Am-241, Pu-238, and Pu-239 comprise the greatest component of internal dose rate. Complete analysis of internal dose rate requires an evaluation of contribution from other radionuclides, such as Eu-152, Eu-154, Sr-90, and Cs-137. Direct comparisons between converted RIDP measurements and CAU 370 average soil sample results were completed. The results showed poor correlation for Sr-90, reasonable correlation for Cs-137, and some clear outliers for Eu-152 and Eu-154. 
There was also variability in CAU 370 soil sample results across sample plots. The sources of these differences are the same as those noted above for Am-241, Pu-238, and Pu-239. Sr-90 differences also result from a technically invalid assumption on the part of the RIDP that a ratio between Cs-137 and Sr-90 would yield accurate Sr-90 concentration values. This is not a valid assumption and is discussed in Section 5.1 .

Eu-152 is a soil activation product produced when the neutrons resulting from nuclear fission interact with soil. As such, Eu-152 contamination extends to greater depths than other radionuclides and in some cases increases with depth. Eu-152 contaminant distribution with depth is more variable than Am-241, $\mathrm{Pu}-238$, and $\mathrm{Pu}-239$, which also causes greater differences in the direct comparisons of converted RIDP data and CAU 370 soil sample data for these radionuclides.

Again, the sources of these differences are related to uncertainty in both RIDP data and CAU 370 soil sample results. The differences between the two characterization methods are expected. However, errors in the data sets and differences between the two data sets are inconsequential to the calculation of internal dose rates for these radionuclides.

To support this conclusion, the following analysis was completed:

- The internal dose rate resulting from these radionuclides was calculated using converted RIDP data and CAU 370 average soil sample results. This calculation was based on the draft CAU 370 DCGs for internal dose.

- The maximum difference between these internal dose rate values was determined.

- The internal dose rate resulting from these radionuclides was determined for all RIDP measurements across the NTS, and the maximum was selected. This calculation was based on the draft CAU 370 DCGs for internal dose.

- It was assumed that the maximum percentage difference determined at CAU 370 would apply to the highest internal dose rate identified across the NTS.

- The resulting worst-case internal dose rate resulting from these radionuclides was $0.5 \mathrm{mrem} / \mathrm{IA}-\mathrm{yr}$.

The differences between the converted RIDP values and the CAU 370 soil sample results could be investigated, and the sources of the differences could be identified and roughly quantified. However, the above analysis clearly demonstrates that additional research would not add value because these radionuclides do not contribute to internal dose rates. Therefore, accurate measurements are not needed for these radionuclides.

\subsubsection{2 $\quad$ Corrective Action Unit 370 External Dose Rates}

Internal and external dose rates were measured and calculated separately and by two different methods during the CAU 370 CAI. External dose rates were determined during the CAU 370 CAI using TLDs. TLDs measured the total exposure over the time period they were placed in the field. The data were then converted to units of mrem/IA-yr to determine external dose rate for CAU 370. RIDP data were evaluated to determine accuracy in determining external dose rate through a number of methods that yielded varying results. Table 2 lists the CAU 370 TLD measurements and external dose rates calculated several ways using RIDP data and other CAU 370 data. 
TABle 2. SumMary CoMPARISON OF EXTERnAL DOSE RATE RESUltS

\begin{tabular}{|c|c|c|c|c|c|c|c|c|}
\hline \multirow[b]{2}{*}{ RIDP ID } & \multirow[b]{2}{*}{$\begin{array}{c}\text { CAU } 370 \\
\text { SAMPLE PLOT } \\
\text { ID }\end{array}$} & \multirow[b]{2}{*}{$\begin{array}{c}\text { CAU } 370 \\
\text { EXTERNAL } \\
\text { DOSE RATE } \\
\text { TLD } \\
\text { (mrem/IA-yr) }\end{array}$} & \multicolumn{2}{|c|}{$\begin{array}{c}\text { Calculated Dose Rates Based on } \\
\text { Activity per Unit Mass }\end{array}$} & \multicolumn{2}{|c|}{$\begin{array}{l}\text { Calculated Dose Rates Based on } \\
\text { RIDP Measurements Directly }\end{array}$} & \multicolumn{2}{|c|}{$\begin{array}{l}\text { Calculated Dose Rates Based on } \\
\text { Direct Reading Instrumentation }\end{array}$} \\
\hline & & & $\begin{array}{c}\text { CAU } 370 \\
\text { SOIL } \\
\text { SAMPLES } \\
\text { (mrem/IA-yr) }\end{array}$ & $\begin{array}{c}\text { CONVERTED } \\
\text { RIDP } \\
\text { (mrem/IA-yr) }\end{array}$ & $\begin{array}{c}\text { DIRECT RIDP } \\
\text { (BECK) } \\
\text { (mrem/IA-yr) }\end{array}$ & $\begin{array}{c}\text { DIRECT RIDP } \\
\text { (A\&D) } \\
\text { (mrem/IA-yr) }\end{array}$ & $\begin{array}{l}1994 \text { AERIAL } \\
\text { SURVEY } \\
\text { (mrem/IA-yr) }\end{array}$ & $\begin{array}{c}\text { CAU 370 } \\
\text { FIELD } \\
\text { SURVEY } \\
\text { (mrem/IA-yr) }\end{array}$ \\
\hline KE0003 & A & 173 & 257 & 239 & 188 & 447 & 343 & 149 \\
\hline KE0008 & $\mathrm{C}$ & 132 & 171 & 173 & 135 & 316 & 206 & 81 \\
\hline KE0009 & $\mathrm{E}$ & 10 & 16 & 14 & 13 & 33 & 62 & 14 \\
\hline KE0014 & $\mathrm{J}$ & 10 & 11 & 16 & 14 & 31 & 62 & 2 \\
\hline KE0020 & $\mathrm{P}$ & 21 & 12 & 15 & 13 & 32 & 62 & 14 \\
\hline KE0021 & M & 153 & 183 & 169 & 125 & 276 & 206 & 104 \\
\hline KE0052 & $\mathrm{F}$ & 141 & 206 & 153 & 120 & 283 & 343 & 104 \\
\hline KE0053 & $\mathrm{H}$ & 166 & 144 & 141 & 109 & 255 & 206 & 104 \\
\hline
\end{tabular}

RIDP ID: Location ID of the RIDP in situ measurement

CAU 370 Sample Plot ID: CAU 370 CAI soil sample plot. A large plot was used in an attempt to replicate the large field of view (sample size) acquired by the RIDP in situ measurements.

CAU 370 External Dose Rate TLD: The dose rate calculated using the TLDs hung at each sample plot. This value was used to calculate external dose rate for CAU 370.

CAU 370 Soil Samples: The dose rate calculated using the CAU 370 soil sample results and the dose conversion factors in Federal Guidance Report (FGR) 12 (U.S. Environmental Protection Agency [EPA], 1993), the same factors used in The RESRAD code.

Converted RIDP: The dose rate calculated using RIDP values converted to pCi/g and the dose conversion factors in FGR 12 (EPA, 1993).

Direct RIDP (Beck): The dose rate calculated using the RIDP measurements directly and the dose conversion factors developed by Beck (1980).

Direct RIDP (A\&D): The dose rate calculated using the RIDP measurements directly and the dose-based limits in Anspaugh and Daniels (1995).

1994 Aerial Survey: The dose rates calculated using the aerial survey values converted to and normalized to 2,250 hours for the industrial use scenario.

CAU 370 Field Survey: The dose rate measured with field instrumentation during the CAU 370 CAI. 
Table 2 demonstrates that each approach to calculating external dose rates has strengths and weaknesses. The following three distinct comparisons were made to evaluate the effectiveness of various approaches to use the RIDP data:

1) The first set of comparisons uses calculated dose rates based on activity per unit mass (pCi/g). The CAU 370 soil sample data were converted to external dose rates in units of mrem/IA-yr using the conversion factors in the RESRAD code. These values were compared to the CAU 370 TLD-measured dose rates, and the comparison is shown in Figure 8.

The RIDP data were converted to units of pCi/g using the method in Appendix A and then converted to external dose rates in units of mrem/IA-yr using the conversion factors in the RESRAD code. These values were also compared to the CAU 370 TLD-measured dose rates, and the comparison is shown in Figure 9.

Figures 8 and 9 show good comparison between the calculated and measured dose rates. The RIDP results show a slightly closer correlation to the TLD measurements than the CAU 370 soil sample results. The two data sets indicate that at least one TLD result may be biased high.

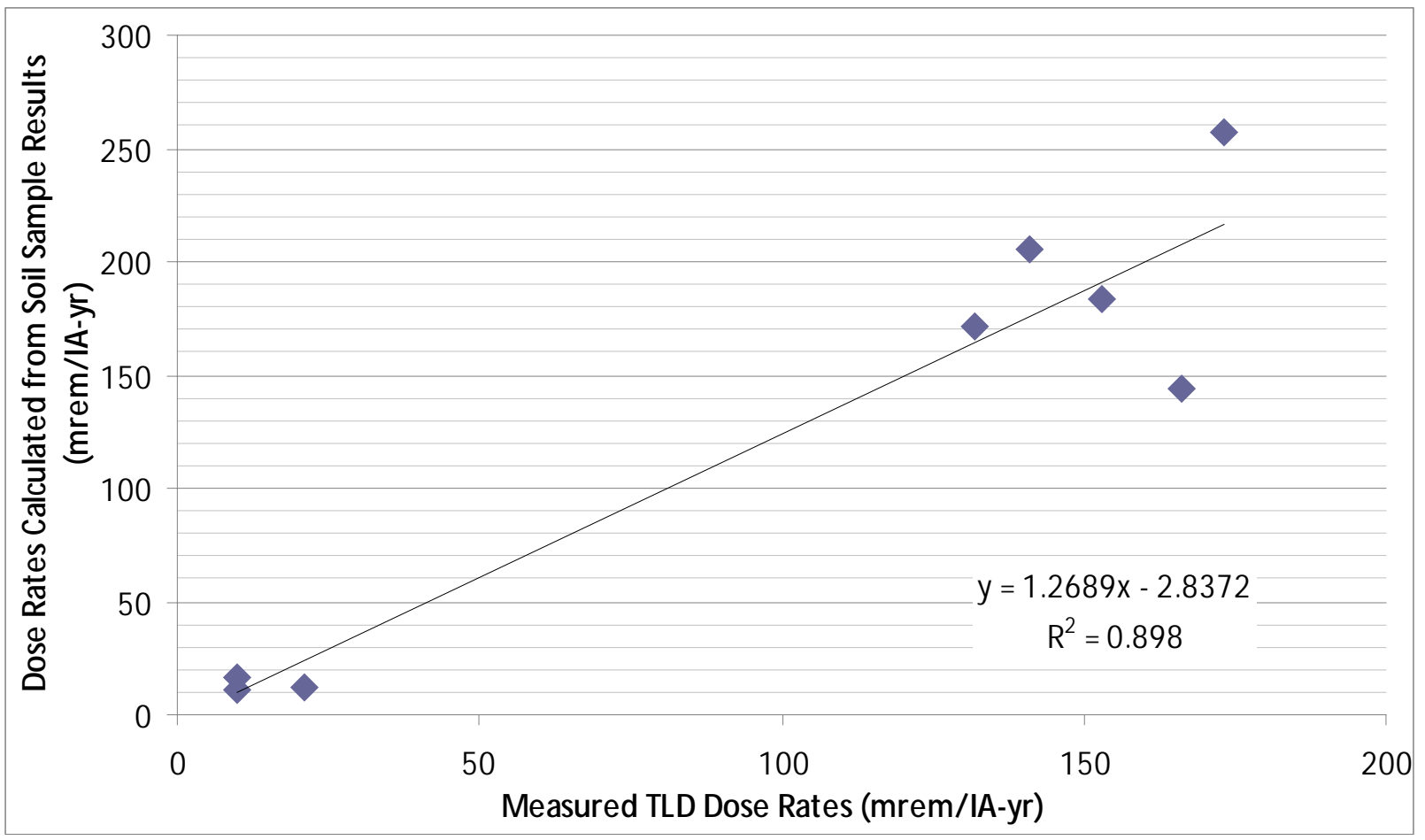

Figure 8. CAU 370 TLD RESUlts CoMPARED TO CAU 370 SOIL SAMPLE RESUlTS 


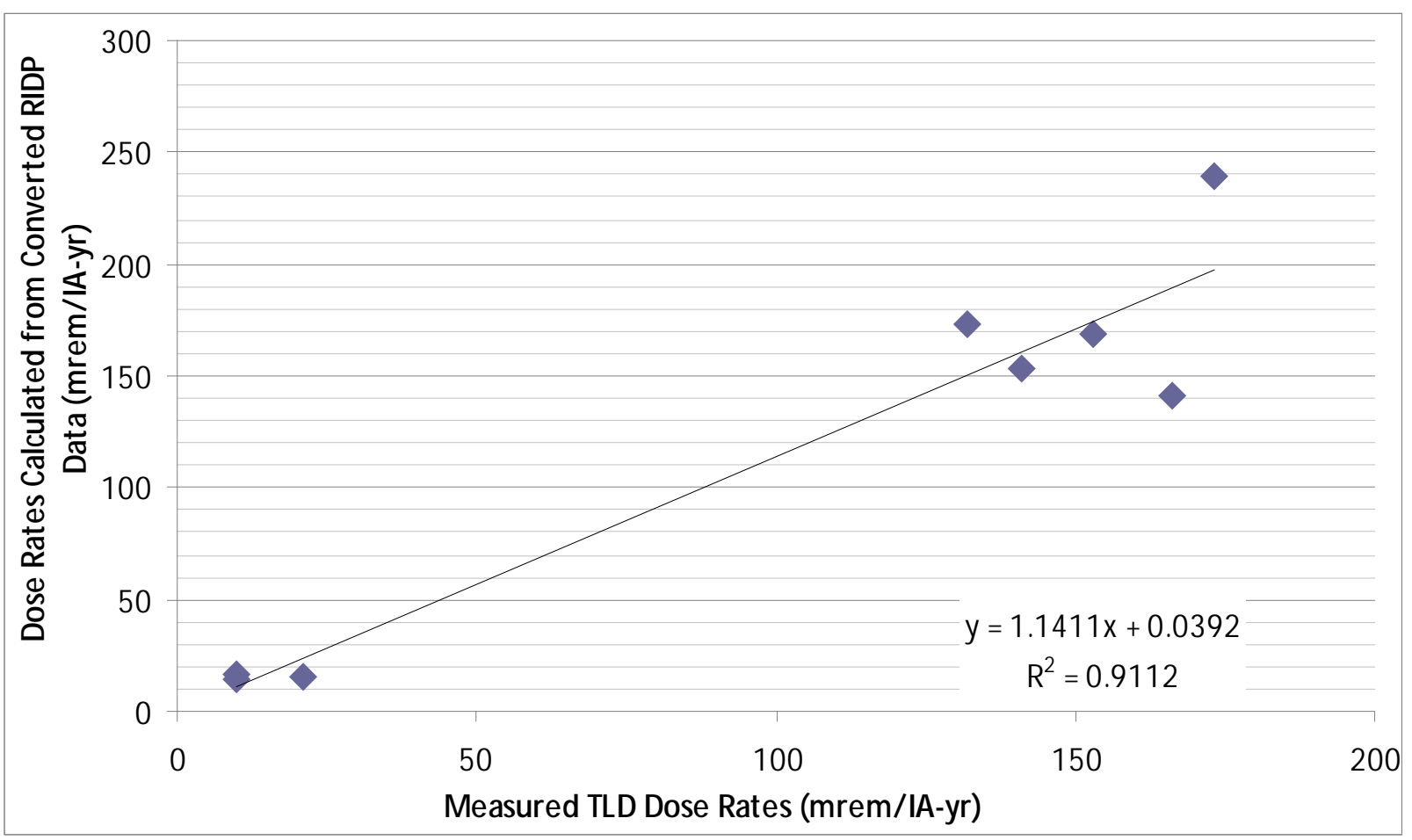

\section{FiguRE 9. CAU 370 TLD RESULTS COMPARED TO CONVERTED RIDP DATA}

2) The second set of comparisons uses external dose rates calculated directly from RIDP data in units of activity per unit area $\left(\mathrm{nCi} / \mathrm{m}^{2}\right)$ without first converting the RIDP data to units of $\mathrm{pCi} / \mathrm{g}$. Figures 10 and 11 compare the CAU 370 TLD-measured dose rates to the calculated external dose rates. This comparison was done using two approaches.

The first approach used conversion factors from Beck (1980) calculated for exponentially distributed radionuclides in soil. The Beck factors allow for a direct conversion from the RIDP data reported in $\mathrm{nCi} / \mathrm{m}^{2}$ to exposure rates without the use of the RESRAD code or other modeling codes. Exposure rates were converted to dose rates using the following conversion factors:

- Exposure to dose-in-air: $0.87 \mathrm{rad} / \mathrm{R}$ (United Nations Scientific Committee on the Effects of Atomic Radiation [UNSCEAR], 1988)

- Dose-in-air to effective dose equivalent: $0.7 \mathrm{rem} / \mathrm{rad}$ (UNSCEAR, 1988)

Figure 10 illustrates the comparison of CAU 370 TLD-measured dose rates to the RIDP data converted using the Beck coefficients. The data are well correlated. This approach to external dose rate calculation also indicates that at least one TLD result may be biased high.

While the external dose rates calculated using the Beck coefficients are not as strongly correlated as the values calculated using converted RIDP values and FGR 12 dose rate conversion factors, they yield closer absolute value comparisons. The data show that using the Beck coefficients is the better approach. This is because the Beck coefficients were specifically derived for soil contamination at nuclear weapons test sites and account for the exponential contaminant distribution with depth, which the FGR 12 values do not. 


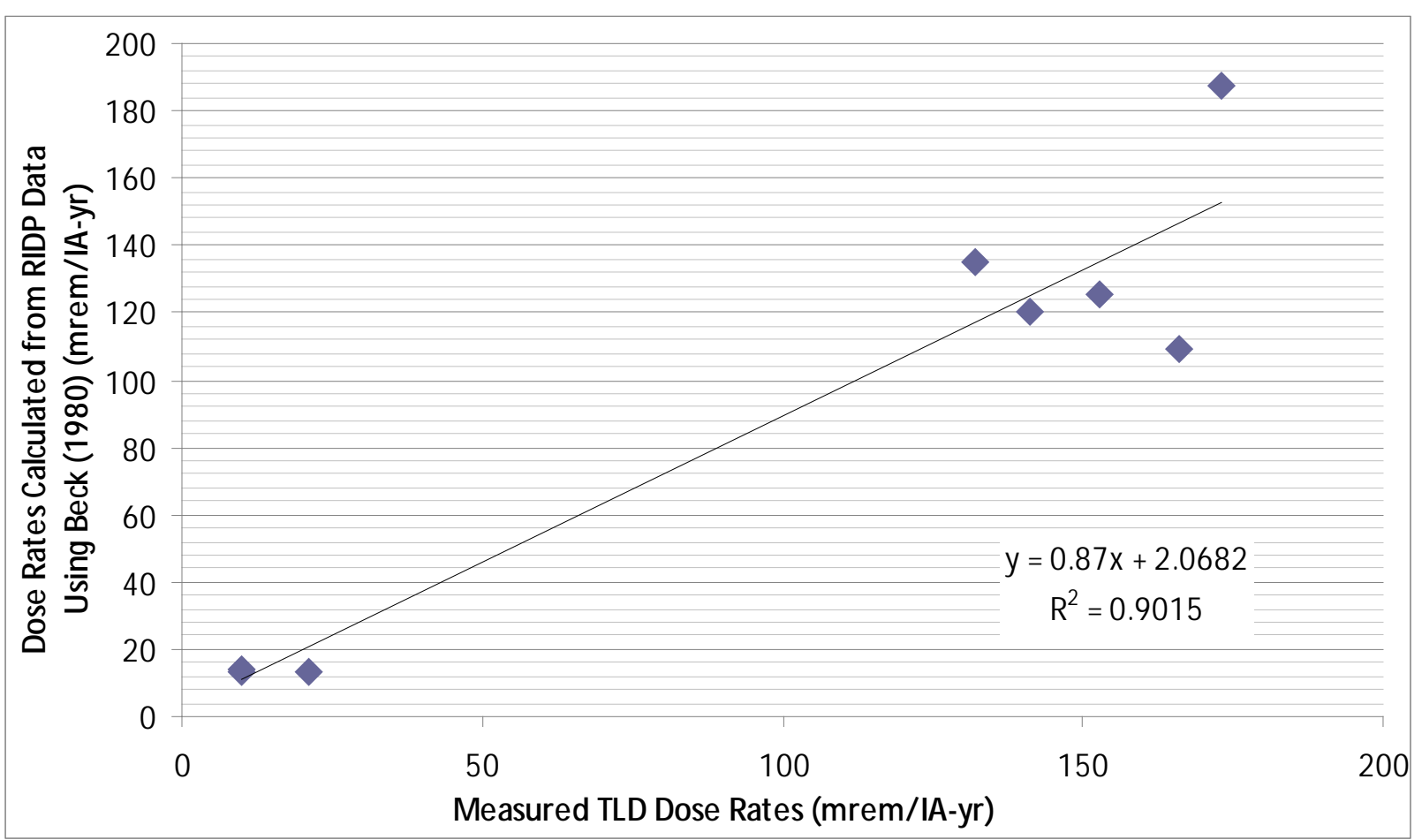

\section{FIGURE 10. CAU 370 TLD RESULTS COMPARED TO RIDP DATA USING BECK (1980) CONVERSION FACTORS}

The second approach used the dose-based limits derived by Anspaugh and Daniels (1995). Figure 11 compares the CAU 370 TLD-measured dose rates to the RIDP data using this approach. The data are highly correlated, but the calculated external dose rates are higher than the TLD-measured dose rates. This is due to the intentional conservatism in the Anspaugh and Daniels dose-based limits. In addition, this method did not easily allow the internal dose component from gamma-emitting radionuclides to be removed. These factors cause a high bias in the calculated data. Given this high bias, external dose rates based on the Anspaugh and Daniels limits that are currently available should be used as a screening and planning tool only. 


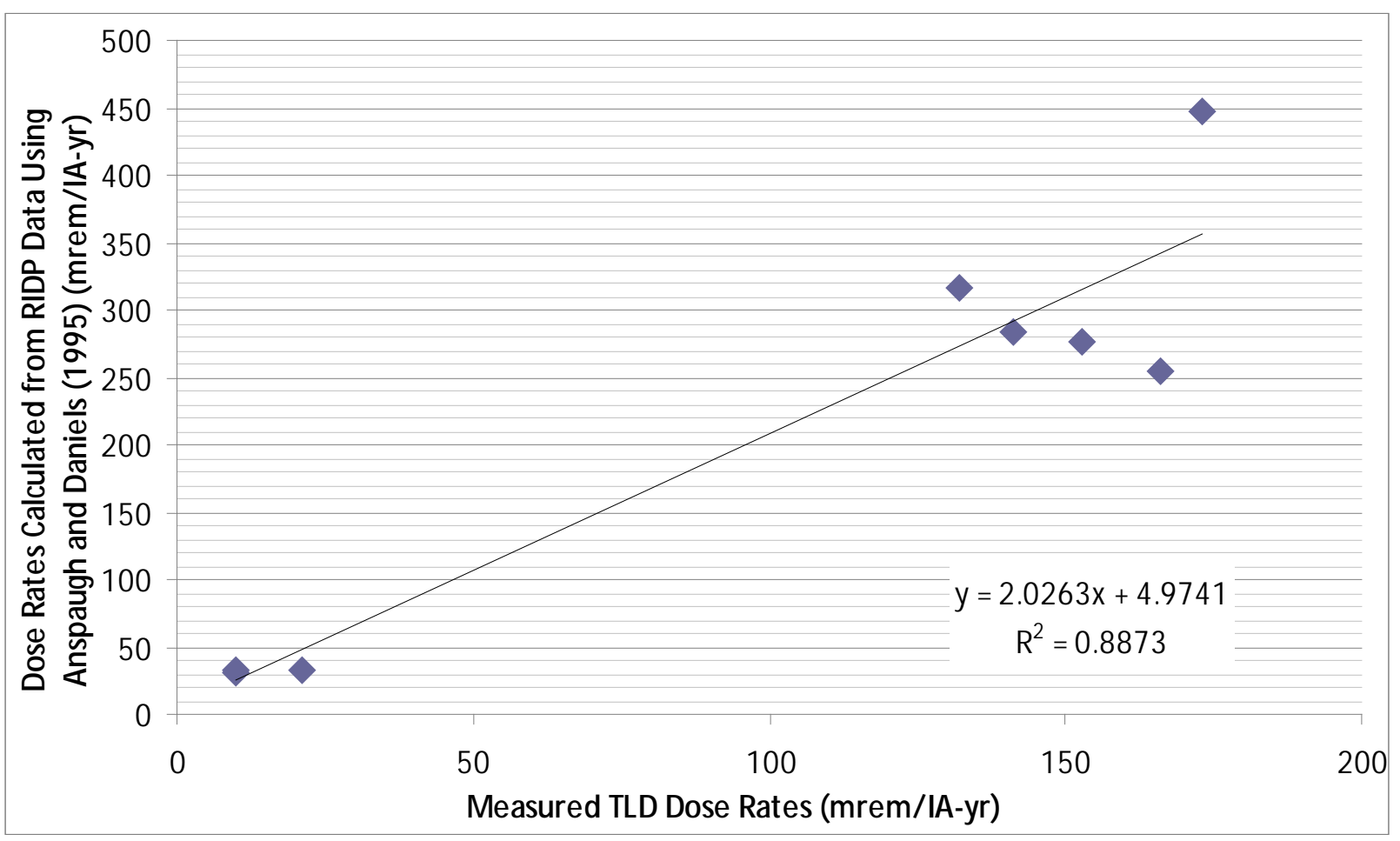

FiguRE 11. CAU 370 TLD RESULTS COMPARED TO RIDP DATA USINg ANSPAUgh AND DANIELS (1995) DOSE-BASED LIMITS

3) The third set of comparisons made to evaluate the effectiveness of the RIDP data uses external dose rates calculated directly from RIDP data using the Beck (1980) coefficients. These values are compared to the results of direct-reading field surveys conducted during the CAU 370 CAI and to the 1994 aerial radiological survey data.

Figure 12 compares the RIDP data to the CAU 370 direct-reading field survey data. Figure 13 compares the RIDP data to the 1994 aerial radiological survey data. Both the CAU 370 direct-reading field survey data and the aerial radiological survey data show good correlation to the external dose rate values calculated using RIDP measurements directly and applying Beck's exposure conversion factors. 


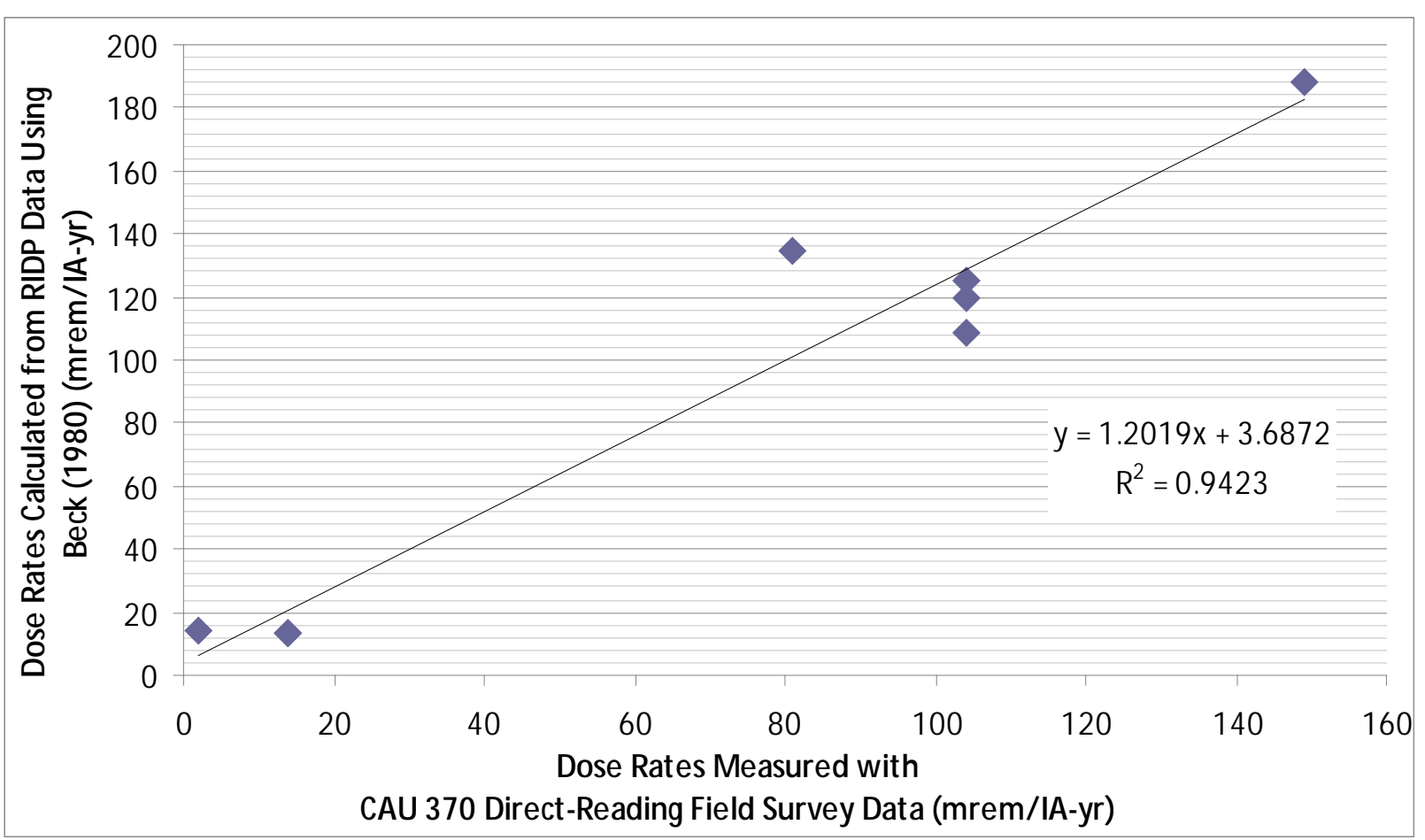

FIGURE 12. CAU 370 DIRECT-READING FIELD SURVEY RESULTS COMPARED TO RIDP DATA USING BECK (1980) CONVERSION FACTORS

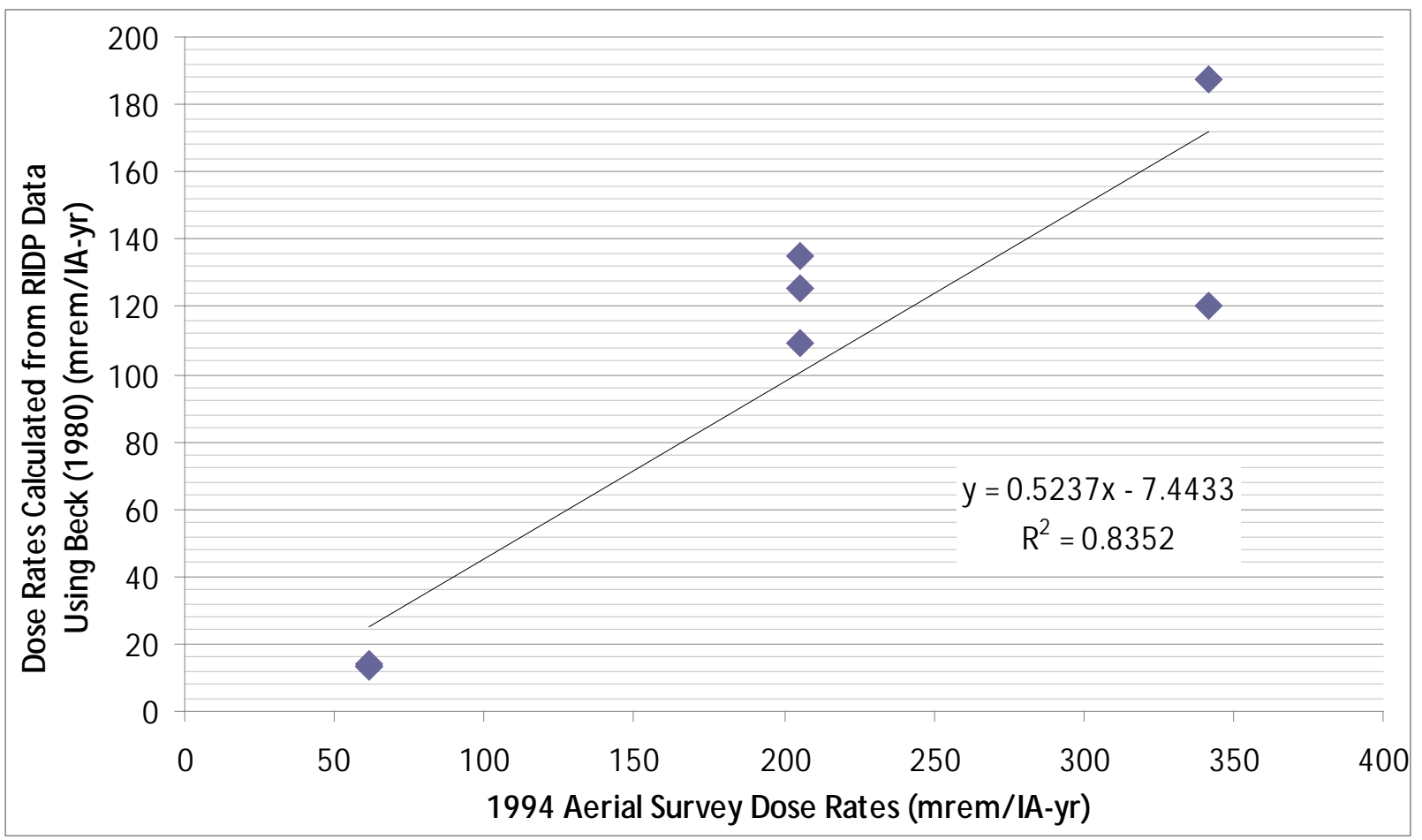

FiguRE 13. 1994 AERIAL SURVEY RESUlTS COMPARED TO RIDP DATA USING BECK (1980) CONVERSION FACTORS 
The three sets of data comparisons presented above demonstrate that the RIDP data can be used to accurately determine external dose rates. Additional sampling at CAU 370 did not yield better results than the RIDP data. In fact, the RIDP data converted to pCi/g yielded a stronger comparison to the TLD data than the actual CAU 370 soil sample data; however, neither data set yielded equivalent results. Both sets of results were higher than the TLD values.

The RIDP values used directly to calculate external dose rates using Beck's coefficients provided the best correlation to the TLD data of any of the data comparisons and scored well on a paired t-test (a statistical test used to determine differences between data sets). The results presented above show that the use of RIDP data to determine external dose rates at CAU 370 yield reasonably accurate results.

The largest differences between external dose rates calculated with RIDP and TLD measurements occurred at locations where the TLDs measured dose rates greater than $25 \mathrm{mrem} / \mathrm{IA}-\mathrm{yr}$. The IRL at these locations is also $0.05 \mathrm{~cm}^{-1}$. An IRL of $0.05 \mathrm{~cm}^{-1}$ represents the far end of the exponential depth distribution assumption, and deviations in actual depth distribution from calculated depth distribution will produce larger errors in dose rates in this region of the curve.

In an effort to further investigate this error and its implications to NTS-wide use of the RIDP data for calculation of external dose rates, comparisons between TLD data and RIDP data were made across the NTS where RIDP measurements were relatively close to environmental TLD monitoring locations. This evaluation indicated that most of the larger deviations between these two values occurred at locations where the applied IRL is $0.05 \mathrm{~cm}^{-1}$. Understanding the source of RIDP error relative to TLD values will allow quantification of the error and a method to mitigate the risk associated with the error. Additional discussion is provided in Section 5.2.2.

\subsubsection{Corrective Action Unit 370 Internal and External Dose Rates Summary}

The final assessment completed was to determine the 25-mrem/IA-yr dose rate boundary using RIDP values and compare it to the 25-mrem/IA-yr boundary determined with the results of the CAU 370 CAI. The RIDP 25-mrem/IA-yr boundary was established by using direct RIDP measurements and the Beck coefficients. The internal dose rate was determined using RIDP values converted to pCi/g as outlined in Appendix A and the draft DCGs established for CAU 370. As Figure 14 shows, the location of the 25-mrem/IA-yr boundary is the same using either data set. 


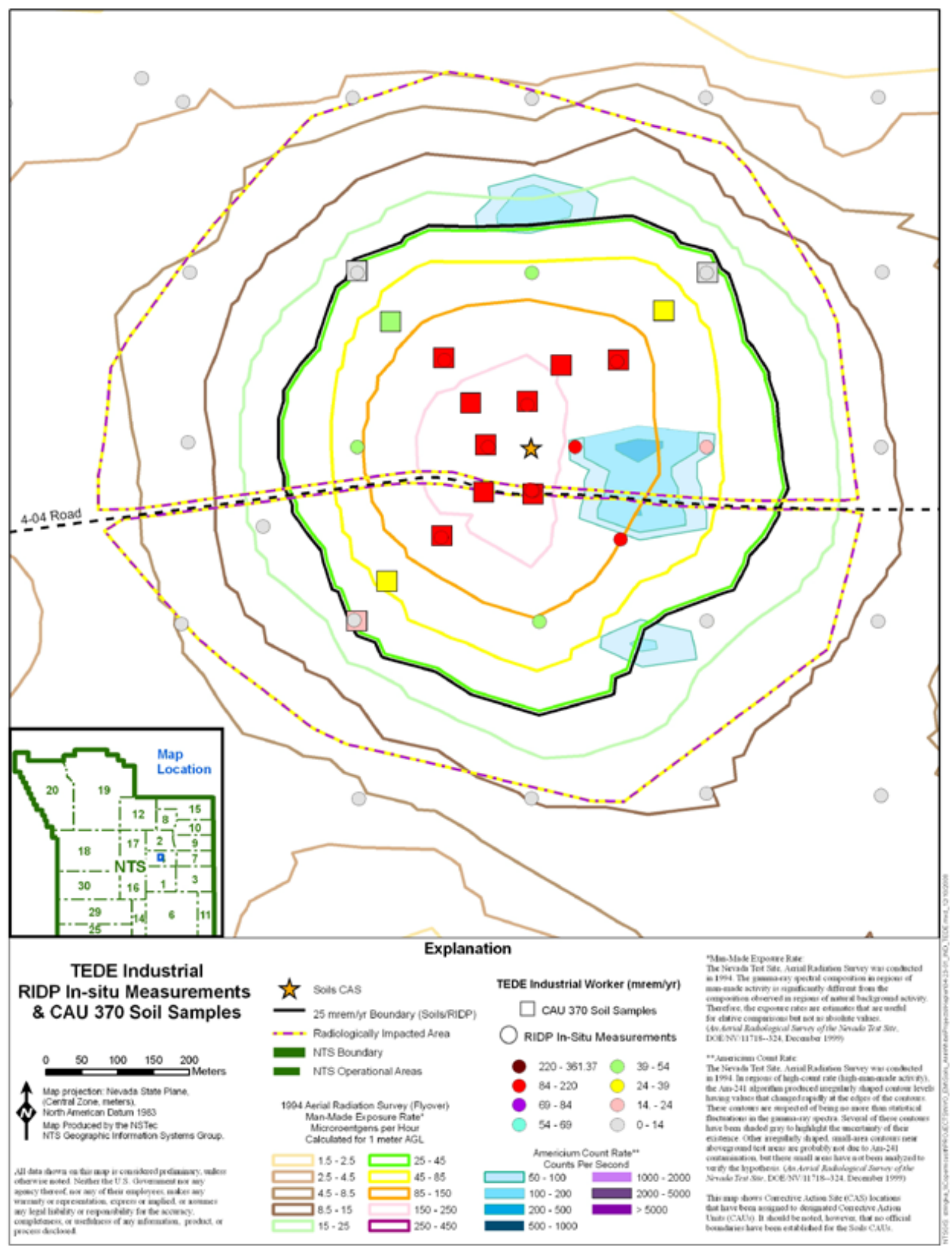

FIGURE 14. RIDP 25-MREM/IA-YR DOSE BOUNDARY FOR CAU 370 


\subsection{Data Cautions and Use}

\subsection{RIDP Data Cautions}

The RIDP data are currently usable, but the following cautions on RIDP data use have been identified. These cautions can be managed through conservative assumptions and some additional research or limited characterization:

- Some ratios of Pu-238 and Pu-239/240 to Am-241 are higher than expected, such as for measurements collected in the WILSON area. However, these high ratios, if incorrect, would result in deriving higher than actual activities, so the results using the existing ratios would be conservative.

- Applying the ratios of Sr-90 to Cs-137 to calculate aged Sr-90 contamination is not reliable. The ratios of Pu-238 and Pu-239/240 to Am-241 are based on the physics of radioactive decay, but the ratios of Sr-90 to Cs-137 are not. These two radionuclides are produced independently of each other and are not in the same decay chain. This means that different ratios would be expected at different sites, with little if any process knowledge to evaluate the ratios. Additionally, Sr-90 is more mobile in the environment than Cs-137, resulting in additional potential changes in the ratio over time. However, Sr-90 is not a contributor to internal dose rate, even under the most conservative assumptions, as outlined in Section 4.7.2.1. Because Sr-90 does not contribute to internal dose, an accurate measurement is not needed.

- Some site cleanup carried out under the Waste Consolidation Project (WCP) was performed concurrently with the RIDP, and RIDP measurements were collected before and after cleanup activities at several sites. The RIDP did not identify appreciably different values before and after these cleanup activities were performed. RIDP may not have detected significant differences because the scope of the cleanup only included minimal amounts of slightly contaminated debris or soil hot spots that were not near RIDP sampling locations. However, because clean up activities occurred after the RIDP, sites that were cleaned up under the WCP should be noted and the RIDP data evaluated. Sites where cleanup occurred after the RIDP can be flagged for additional data cautions.

- The RIDP data cannot capture recent contaminant migration. Sites where migration might be an issue may require additional, focused characterization in the known migration channels.

\subsection{RIDP Data Use}

The RIDP data are currently usable for a number of applications given the level of QA reviews performed to date. Enhanced uses of RIDP data may be possible with additional calculations and verification.

\subsubsection{Current RIDP Data Use}

Project Planning: Evaluations of the RIDP data indicate it may be used for project planning without additional field verification. Project planning activities may include estimating 25-mrem/IA-yr dose rate boundaries, optimizing characterization efforts, projecting final end states, and planning remedial actions. Figure 15 provides an example of the 25-mrem/IA-yr dose rate boundary at the GALILEO site. This example highlights a secondary plume that does not follow the pattern observed at CAU 370 of decreasing dose rate with distance from ground zero and indicates that the secondary plume may require an additional land use restriction. The 25-mrem/IA-yr dose rate boundaries have been estimated for all areas of the NTS. Figure 16 provides an example of how RIDP data may be used to optimize characterization efforts. 


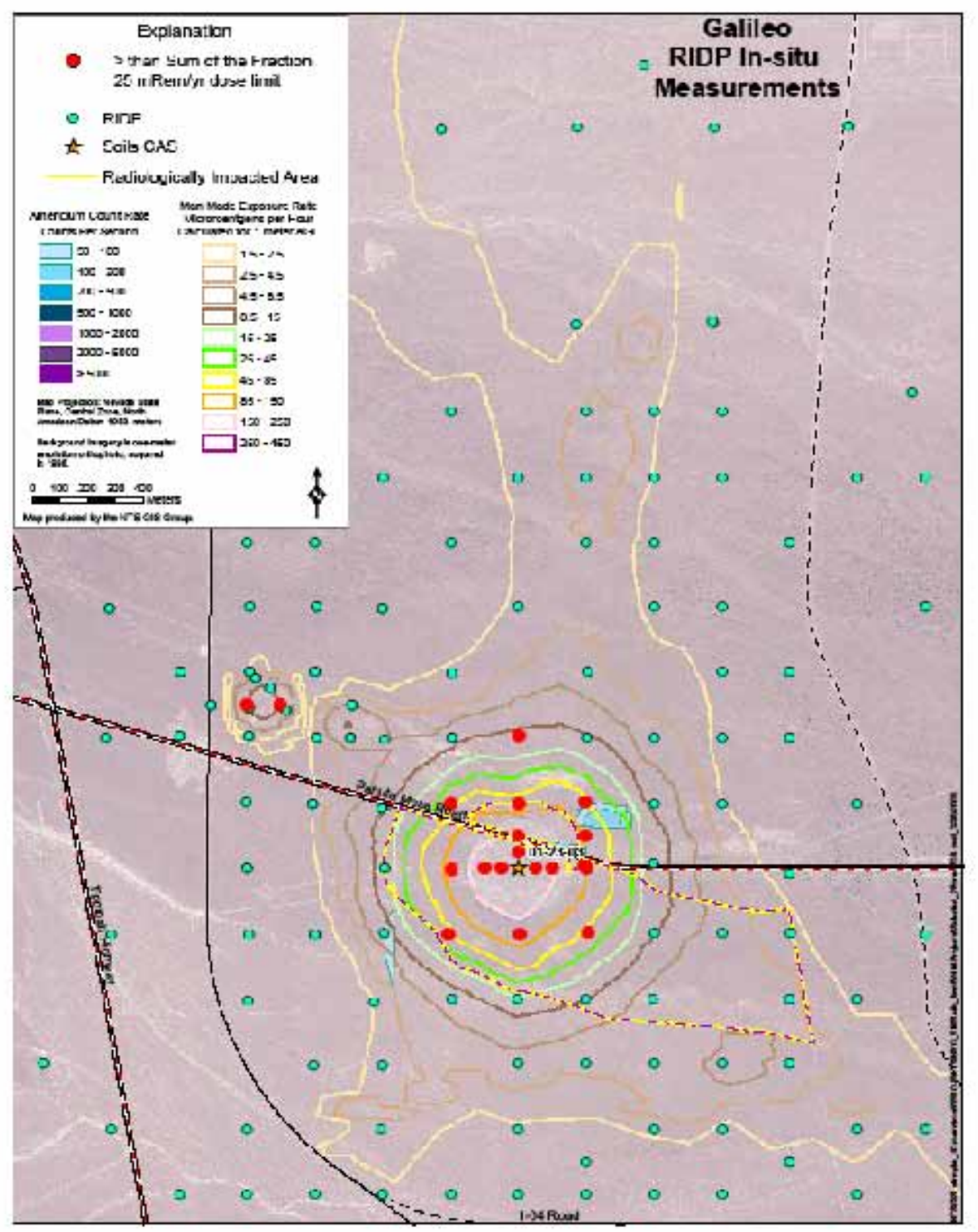

FIGURE 15. EXAMPLE OF ESTIMATED 25-MREM/IA-YR DOSE RATE BOUNDARIES

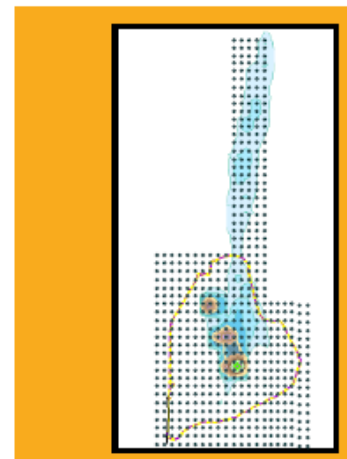

Potential Study Needs

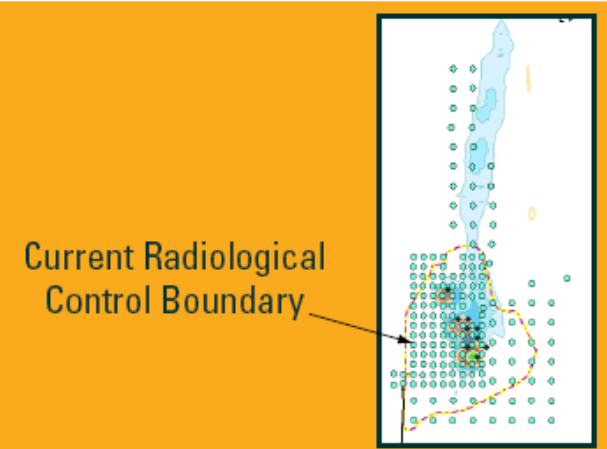

Analyze Historical Data

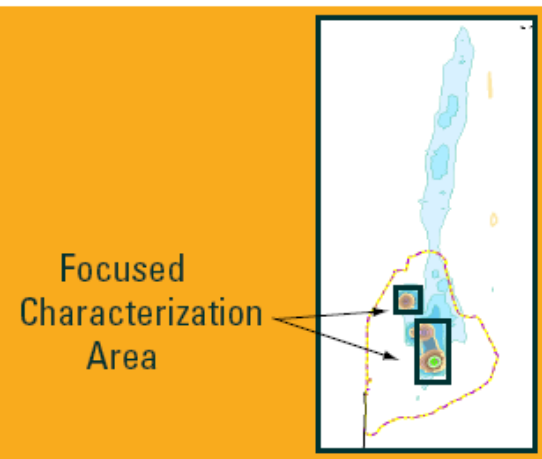

Results in Limited Characterization

Figure 16. Using Historical Data to Optimize Characterization 
Augmenting TLD Data: Approximately 90 percent of the dose rate at CAU 370 is due to external gamma exposure from radionuclides with short half-lives relative to Am-241 and $\mathrm{Pu}-239$. Data collection at CAU 370 used TLDs to determine external dose rates. TLD data cannot be easily corrected for decay. RIDP data can be used to identify specific radionuclide distributions, thus augmenting the CAU 370 data set to allow for decay corrections and dose rate projections for any future date. Less risk will be involved for closure at sites where the dose rate and 25-mrem/IA-yr boundary is steadily decreasing. This approach provides a way to show that the TLD or calculated RIDP dose rate errors steadily decrease over time.

Calculating Dose Rates and Estimating the 25-mrem/IA-yr Boundaries: The RIDP data collected in the CAU 370 area provide reasonably accurate dose rate values for both internal and external dose rates. The RIDP data lead to the same decisions as the newly collected data for CAU 370; therefore, the RIDP data should be used to estimate the 25-mrem/IA-yr boundaries during the DQO process. The estimated boundaries can potentially limit additional characterization requirements. Figure 16 outlines this characterization optimization.

\subsubsection{Enhanced RIDP Data Use}

Several opportunities for enhanced RIDP data use are appropriate based on the evaluations presented in Section 4.7. The evaluations show good agreement between RIDP data and CAU 370 data. The evaluations also help roughly define the magnitude and potential sources of RIDP error. This information can be used to establish some conservative approaches for RIDP data use that will mitigate the risks associated with potential RIDP error without drastically increasing areas of land use restrictions. Three examples of how enhanced RIDP data use may be pursued follow.

Internal Dose Rate Estimates: There is error associated with internal dose rate estimates based on both RIDP data and soil sample results. Section 4.7.2.1 indicates that internal dose rates calculated using converted RIDP values are likely to be accurate within the inherent deviation in soil sample plots. This is expected to be the case due to the variation between soil sample values. Using the process outlined in Section 4.7.2.1, internal dose rates at all RIDP locations across the NTS were calculated. A query was run to determine how many RIDP locations exceeded 25 mrem/IA-yr with an internal dose component greater than 25 percent of the total dose, or 6.25 mrem/IA-yr. Only 47 RIDP locations resulted from this query. The maximum difference between CAU 370 dose rates calculated with soil samples and calculated with converted RIDP values was 50 percent. This error was applied to the 47 values to gain a rough idea of the increase in the size of land use restriction areas using the conservative application of potential error. The adjusted values only resulted in 16 additional points exceeding 25 mrem/IA-yr with an internal dose component greater than 6.25 mrem/IA-yr. This informal and brief evaluation highlights that conservative assumptions may be applied with little impact to the size of land use restriction areas. Using this type of conservative estimate may allow these areas to be characterized with limited additional sampling. This approach would be presented during the DQO process. The outcome of using the RIDP data would reduce worker risk associated with sampling in contaminated areas, accelerate schedules, and reduce project costs.

External Dose Estimates: There is error associated with estimating external dose rates based on TLDs and the RIDP data. Section 4.7.2.2 indicates that RIDP values associated with IRLs of $0.05 \mathrm{~cm}^{-1} \mathrm{can}$ lead to differences between TLD measurements and RIDP-calculated dose rates in some areas. The risk associated with this potential error can be limited by selecting a more conservative Beck coefficient. Many of these locations are at or near ground zero locations, so using a more conservative coefficient to determine dose is unlikely to increase the 25-mrem/IA-yr dose rate boundaries. 
Additional Streamlined Approach for Environmental Restoration (SAFER) Plan: Estimated dose rates for each RIDP measurement location have been calculated in support of this white paper using the process described in Section 4.7.2.3. This information was used to determine Corrective Action Site (CAS) areas that did not exceed a dose rate of 25 mrem/IA-yr. Approximately 20 CAS areas do not have RIDP locations with calculated dose rates greater than 25 mrem/IA-yr. This information can be used to select candidate sites that may be appropriate for closure under the SAFER process. The evaluation of these CASs for inclusion into a proposed SAFER closure will consider similarities to CAU 370, proximity to operating facilities, whether migration is likely, and existing fencing or posting. After the CASs are evaluated against these criteria, DQOs will be prepared that include an evaluation of the RIDP data and a determination of any additional data needs.

\subsection{CONCLUSIONS AND RECOMMENDATIONS}

The following sections provide conclusions based on the evaluations presented above and recommendations for future actions.

\subsection{Conclusions}

Evaluations presented in this white paper indicate the RIDP data may be used under the limitations set forth in Section 5.1 and for the uses outlined in Section 5.2. Task 1 presented below should be implemented prior to the release of the RIDP data as a shared Microsoft Access database.

Enhanced RIDP data use is possible though the implementation of the recommendations provided in the following section.

\subsection{Recommendations}

Recommended activities presented below assume that the enhanced data uses suggested in Section 5.2.2 will be implemented.

\subsubsection{Task 1: Database Finalization}

- Review calculations and the resulting data for query logic and accuracy of calculated output under a formalized approach. A graded approach to software quality assurance will be used to verify that the calculations are appropriate and accurate.

- $\quad$ Migrate the database to a platform for multi-user access.

\subsubsection{Task 2: Evaluation of CAU 371 and CAU 372 Data}

- $\quad$ Determine 25-mrem/IA-yr boundaries using RIDP data.

- Determine sources of potential error either in the RIDP measurements or projected uncertainty associated with characterization and dose assessment for CAU 371 and CAU 372.

- Document any adjustments to the 25-mrem/IA-yr boundaries to account for errors or uncertainty.

- Perform an assessment similar to that presented in this white paper for CAU 371 and CAU 372 data and document the results. 


\subsubsection{Task 3: Calculation of Internal Dose Rates}

- Formalize the initial evaluation in Section 5.2.2 to determine how conservative applications of various assumed errors may affect the size of required land use restrictions.

- If conservative assumptions do not greatly increase the estimated size of land use restrictions, select more conservative correction factors and apply them to the RIDP data to be used during the DQO process.

\subsubsection{Task 4: Calculation of External Dose Rates}

- Formalize the initial evaluation in Section 5.2.2 to determine how conservative applications of various assumed errors may affect the size of required land use restrictions.

- If conservative assumptions do not greatly increase the estimated size of land use restrictions, select more conservative correction factors and apply them to the RIDP data to be used during the DQO process.

\subsubsection{Task 5: Evaluation of Sites for a SAFER Closure}

- $\quad$ Select sites as outlined in Section 5.2.2.

- Evaluate sites under the criteria suggested in Section 5.2.2 and other criteria that may be developed.

- Determine a list of candidate sites that appear to have an obvious closure path, low dose rates, and low project risks.

- Evaluate the sufficiency of RIDP data to develop a list of sites that will require limited additional characterization.

- Change the closure process from complex to SAFER.

- Prepare DQOs that evaluate the RIDP data. 


\subsection{REFERENCES}

Anspaugh, L. R., 1976. In Situ Methods for Quantifying Specific Radionuclides. NS-23, 1190. IEEE Transactions on Nuclear Science. Livermore, CA.

Anspaugh, L. R., and J. F. Kordas, 1980. Assessment of the Nevada Test Site Inventory and Distribution Project. UCRL-52967. Lawrence Livermore National Laboratory. Livermore, CA.

Anspaugh, L. R., and J. I. Daniels, 1995. Development of the Scientific Bases for Establishing the Boundary Conditions Between "Unrestricted Use” and "Posting” for Exposure Due to Residual Radioactive Contamination of Soil at the Nevada Test Site. UCRL-JC-119936. Lawrence Livermore National Laboratory. Livermore, CA.

Beck, H. L., J. Decampo, and C. Gogolak, 1972. In Situ Ge(Li) and Na(T1) Gamma-Ray Spectrometry. HASL-258. Health and Safety Laboratory, U.S. Atomic Energy Commission. New York City, NY.

Beck, H. L., 1980. Exposure rate conversion factors for radionuclides deposited on the ground. EML-378. U.S. Department of Energy Environmental Measurements Laboratory. New York City, NY.

Gray, K. J., D. S. Shafer, K. Self, C. Martin, and R. McArthur, 2007. Radionuclide Inventory and Distribution Program (RIDP) Database, Rev. 2. Desert Research Institute. Las Vegas, NV.

Gunnink, R. and J. B. Niday, 1971. Computerized Quantitative Analysis by Gamma-Ray Spectrometry. Vol. 1-5. UCRL-51061. Lawrence Livermore Laboratory. Livermore, CA.

Helfer, I. K. and K. M. Miller, 1988. Calibration Factors for Germanium Detectors Used for Field Spectrometry. Health Physics.

Hendricks, T. J., and S. R. Riedhauser, 1999. An Aerial Radiological Survey of the Nevada Test Site. DOE/NV/11718--324. Bechtel Nevada for the U.S. Department of Energy. Las Vegas, NV.

Los Alamos Scientific Laboratory, 1971. Proceedings of Environmental Plutonium Symposium Held at LASL. LA-4756. Los Alamos Scientific Laboratory: U.S. Atomic Energy Commission.

McArthur, R. D., and J. F. Kordas, 1983. Nevada Test Site Radionuclide Inventory and Distribution Program: The Galileo Area. DOE/NV/10162-14. Desert Research Institute. Las Vegas, NV.

McArthur, R. D., and J. F. Kordas, 1985. Nevada Test Site Radionuclide Inventory and Distribution Program: Report \#2, Areas 2 and 4. DOE/NV/10162-20. Desert Research Institute. Las Vegas, NV.

McArthur, R. D., and S. W. Mead, 1987. Nevada Test Site Radionuclide Inventory and Distribution Program: Report \#3, Areas 3, 7, 8, 9, and 10. DOE/NV/10384-15. Desert Research Institute. Las Vegas, NV.

McArthur, R. D., and S. W. Mead, 1988. Nevada Test Site Radionuclide Inventory and Distribution Program: Report \#4, Areas 18 and 20. DOE/NV/10384-22. Desert Research Institute. Las Vegas, NV.

McArthur, R. D., and S. W. Mead, 1989. Nevada Test Site Radionuclide Inventory and Distribution Program: Report \#5, Areas 5, 11, 12, 15, 17, 18, 19, 25, 26, and 30. DOE/NV/10384-26. Desert Research Institute. Las Vegas, NV.

McArthur, R. D., 1991. Radionuclides in Surface Soil at the Nevada Test Site. DOE/NV/10845-02. Desert Research Institute. Las Vegas, NV. 
U.S. Environmental Protection Agency, 1993. External Exposure to Radionuclides in Air, Water, and Soil. Federal Guidance Report No. 12. EPA-402-R-93-081. Washington, D.C.

Tipton, W. J., A. E. Fritzsche, and A. E. Villaire, 1978. In situ Determination of 241Am at Enewetak Atoll. RSSE-78-177. EG\&G. Las Vegas, NV.

United Nations Scientific Committee on the Effects of Atomic Radiation, 1988. Sources, effects and risks of ionizing radiation. New York City, NY.

UNSCEAR, see United Nations Scientific Committee on the Effects of Atomic Radiation. 


\section{APPENDiX A RIDP DATA CONVERSION PROCESS}

In situ gamma spectroscopy data were collected during the RIDP. Instrument calibration factors were determined so that the raw gamma count rate could be converted into radionuclide-specific activities. In this case, radionuclide-specific peaks were identified, and raw gamma count rates were converted to units of activity per unit area $\left(\mathrm{nCi} / \mathrm{m}^{2}\right)$. In order to compare these data to dose-based DCGs, the data must be converted to units of activity per unit mass (pCi/g).

The discussion below outlines the approach to data conversion using the IRL as determined through actual soil samples at the NTS supporting the RIDP project and equation 5 from HASL-300.

Equation 5 from HASL-300, the cumulative activity, or inventory I, integrated to a depth z' is:

$I_{z^{\prime}}=\int_{0}^{z^{\prime}} d z=\frac{S_{0}}{\alpha}\left[1-e^{-\left(\alpha z^{\prime}\right)}\right]=I_{0}\left[1-e^{-\left(\alpha z^{\prime}\right)}\right]$

Where:

$S_{0}$ is the activity per $\mathrm{cm}^{3}$ at the soil surface

$\alpha$ is the IRL in $\mathrm{cm}^{-1}$

$\mathrm{z}^{\prime}$ is the contaminant depth

The RIDP data provide $\alpha . \mathrm{I}_{\mathrm{z}^{\prime}}$ and $\mathrm{I}_{0}$ will be represented as a fraction in the following analysis. The RIDP values presented in units of total activity per unit area represent the total activity integrated to an infinite depth. In order to develop a specific activity value (pCi/g), the following procedure is used to avoid "diluting” values by integrating to too great a depth, and thereby calculating values that would underestimate potential dose. The goal is to establish an appropriate depth to which it should be assumed the contamination is largely distributed. The RIDP values represent total activity in the column beneath the unit area reported. In other words, it is the surface representation of the total activity integrated to an infinite depth. The total contamination is assumed to be distributed to a depth that captures 90 percent of the total inventory in the column based on the exponential distribution of the contaminant. This is conservative in that 100 percent of the activity is assumed to reside in only 90 percent of the volume. All radionuclides of concern, other than activation products, reside in the top several $\mathrm{cm}$ of soil and fall off very rapidly with depth, so the method is conservative for these radionuclides. Activation products tend to be present to deeper levels, so the method is very conservative for those radionuclides. Equation 5 above is solved for z', which will then be used to convert activity per unit area to activity per unit volume. A soil density of $1.6 \mathrm{~g} / \mathrm{cm}^{3}$ was used in the RIDP calibrations and is used for this conversion.

Solving for z':

$\frac{I}{I_{0}}=\left[1-e^{-\left(\alpha z^{\prime}\right)}\right]$

Then:

$1-\frac{I}{I_{0}}=e^{-\left(\alpha z^{\prime}\right)}$ 
Then, assuming a 90-percent contaminant capture depth:

$$
.1=e^{-\left(\alpha z^{\prime}\right)}
$$

Then, solving for z':

$$
\frac{\operatorname{Ln}(.1)}{\alpha}=-z^{\prime}
$$

The RIDP data contain the appropriate $\alpha$ for each region of in situ values, thus the procedure for solving for $z$ ' is to write a query to carry out the function above. The value of $z$ ' will then be multiplied by the RIDP value in activity per unit area. These values will then be divided by the soil density to arrive at the activity per unit mass (pCi/g). 
CAU 574 Closure Report

Section: Appendix C

Revision: 0

Date: April 2012

\section{THIS PAGE INTENTIONALLY LEFT BLANK}


Revision: 0

Date: April 2012

\section{LIBRARY DISTRIBUTION LIST}


CAU 574 Closure Report

Section: Library Distribution List

Revision: 0

Date: April 2012

\section{THIS PAGE INTENTIONALLY LEFT BLANK}




\section{LIBRARY DISTRIBUTION LIST}

U.S. Department of Energy

National Nuclear Security Administration

Nevada Site Office

Technical Library

P.O. Box 98518, M/S 505

Las Vegas, NV 89193-8518

U.S. Department of Energy

Office of Scientific and Technical Information

P.O. Box 62

Oak Ridge, TN 37831-0062

Southern Nevada Public Reading Facility

c/o Nuclear Testing Archive

P.O. Box 98521, M/S 400

Las Vegas, NV 89193-8521

Manager, Northern Nevada FFACO

Public Reading Facility

c/o Nevada State Library \& Archives

Carson City, NV 89701-4285
1 (Uncontrolled, electronic copy)

1 (Uncontrolled, electronic copy)

2 (Uncontrolled, electronic copies)

1 (Uncontrolled, electronic copy) 
CAU 574 Closure Report

Section: Library Distribution List

Revision: 0

Date: April 2012

THIS PAGE INTENTIONALLY LEFT BLANK 